UNIVERSIDADE DE SÃO PAULO

FACULDADE DE EDUCAÇÃO

DANIELA GOMES DE ALBUQUERQUE FERREIRA

Ginásio Estadual Vocacional

"Cândido Portinari" de Batatais:

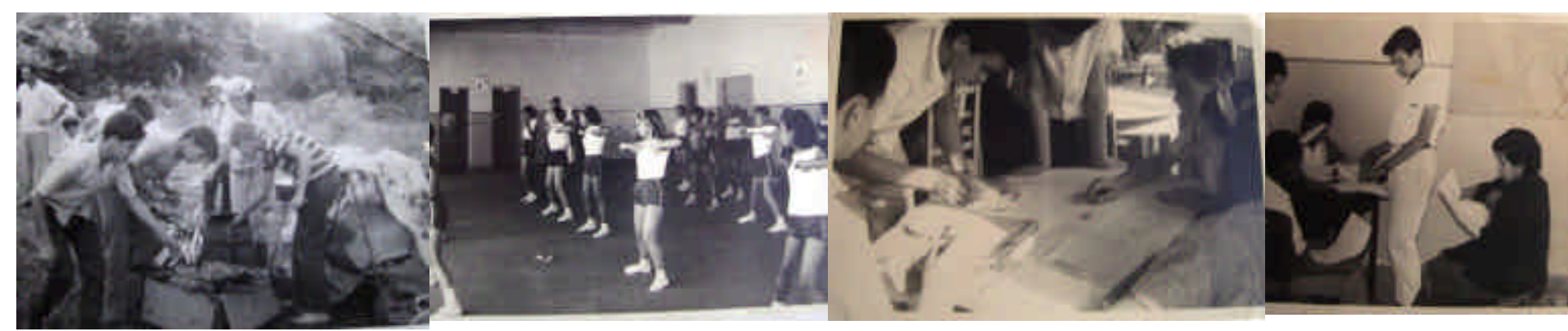

Histórias, Sujeitos e Práticas 

DANIELA GOMES DE ALBUQUERQUE FERREIRA

\section{Ginásio Estadual Vocacional "Cândido Portinari" de Batatais: Histórias, Sujeitos e Práticas}

Dissertação de Mestrado apresentada à Faculdade de Educação da Universidade de São Paulo para obtenção do título de Mestre em Educação.

Área de Concentração: História e Historiografia da Educação Orientadora: Profa. Dra. Maurilane de Souza Biccas

São Paulo

2007 
AUTORIZO A REPRODUÇÃO E DIVULVAÇÃO TOTAL OU PARCIAL DESTE

TRABALHO, POR QUALQUER MEIO CONVENCIONAL OU ELETRÔNICO, PARA FINS DE ESTUDO E PESQUISA, DESDE QUE CITADA A FONTE.

Catalogação na Publicação

Serviço de Biblioteca e Documentação

Faculdade de Educação da Universidade de São Paulo

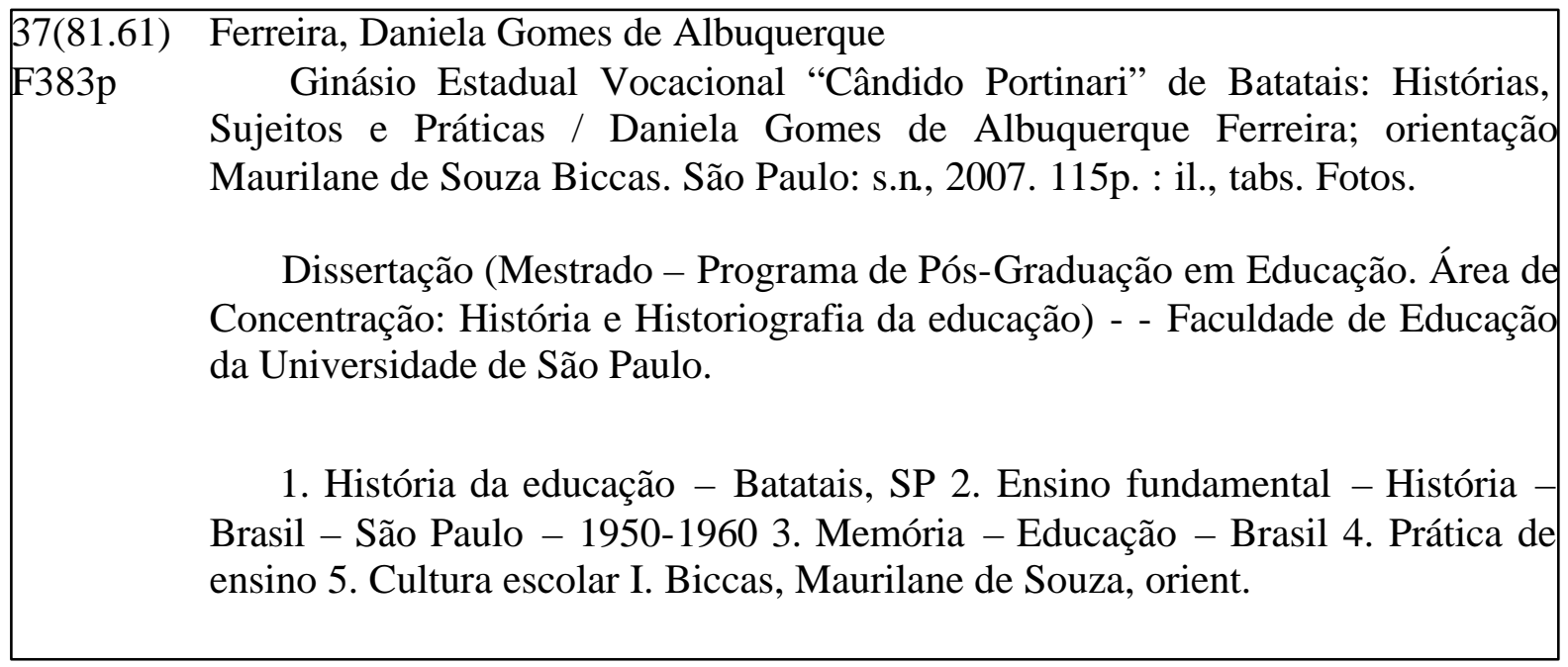




\section{FOLHA DE APROVAÇÃO}

Daniela Gomes de Albuquerque Ferreira

Ginásio Estadual Vocacional "Cândido Portinari” de Batatais: Histórias, Sujeitos e Práticas

Dissertação de Mestrado apresentada à Faculdade de Educação da Universidade de São Paulo para obtenção do título de Mestre em Educação.

Área de Concentração: História e Historiografia da Educação

Aprovado em:

Banca Examinadora

Prof. Dr.

Instituição:

Assinatura:

Prof. Dr.

Instituição:

Assinatura:

Prof. Dr.

Instituição:

Assinatura:

Prof. Dr.

Instituição: Assinatura: 
Dedico este trabalho

Ao Gustavo, companheiro amoroso que me auxiliou nessa jornada. E a minha família que sem eles, eu não estaria aqui. 


\section{AGRADECIMENTOS}

Em primeiro lugar, gostaria de agradecer a Deus pela vida. Aos meus pais que se mostraram espíritos corajosos permitindo que eu e minhas irmãs viéssemos ao mundo.

As minhas irmãs que me mostraram que a distância nos aproxima cada vez mais, as minhas avós e avôs (em memória) pela confiança e incentivo constante. E não poderia deixar de agradecer ao meu marido, companheiro de longa data a quem devo amor e gratidão por tudo que construímos juntos até o momento.

Em especial, a colega que ao longo desses três anos conquistou um lugar no meu coração. Ana Cláudia, obrigada por termos sido companheiras e desfrutar de momentos de pura satisfação e encantamento por nossos objetos e fontes, mas também pelos momentos menos felizes e certamente esperados, a ansiedade gerada por conta de uma preocupação e uma vontade imensa de ver os nossos trabalhos concluídos.

Aos amigos da infância, da juventude, dos tempos de graduação (nas figuras de Solange, Sandrinha e das Profas. Rita e Ilíada), que me auxiliaram muito durante essa jornada. Aos amigos da pós-graduação, em especial os amigos do NIEPHE e aos companheiros de ideal da Associação Espírita de Caminheiros em Busca da Paz e do Núcleo Kardecista "Antonio Pereira de Souza".

Poderia me estender nos agradecimentos, mas peço a permissão dos amigos, para que se sintam todos abraçados e agradecidos pela convivência e conquistas que juntos realizamos.

Gostaria de agradecer imensamente a minha orientadora: a Profa. Dra. Maurilane de Souza Biccas, pela orientação, incentivo, confiança, dedicação e convivência que marcaram essa etapa da minha trajetória. 
Fica meus agradecimentos a Banca de Qualificação, nas presenças da Profa.. Dra. Maria Lucia Spedo Hilsdorf e a Profa. Dra. Ângela Rabello Maciel de Barros Tamberlini.

Agradeço à CAPES pelo financiamento oferecido através da concessão de bolsa de estudos.

Para finalizar, deixo com carinho meus agradecimentos ao Dr. Ricardo, ao Dr. Adão Nonato e à equipe do Dr. Carlos, a quem sou muito grata pela compreensão e seriedade durante essa empreitada. 


\section{RESUMO}

Esse trabalho teve como objeto de pesquisa o Ginásio Vocacional "Cândido Portinari" (GVCP), instituição pública de Ensino Secundário que funcionou entre os anos de 1962 a 1969, na cidade de Batatais, interior do Estado de São Paulo. O objetivo desta pesquisa foi fazer uma história institucional do GVCP mediante as práticas construídas por seus ex-alunos e que foram referenciadas em seus depoimentos. Tais práticas foram analisadas através de diferentes fontes: entrevistas com ex-alunos, fotografias de época e documentos sobre a instituição. Isto permitiu confrontar os depoimentos dos ex-alunos com as práticas previstas nos Planos Pedagógicos e Administrativos (PPA) da instituição e com o que ficou registrado nas fotografias da experiência. Também foi possível perceber os aspectos da experiência que mais marcaram os ex-alunos e a maneira como essas práticas foram apropriadas pelos mesmos.

Palavras-chave: Ginásios Vocacionais, Práticas, História Institucional, Cultura Escolar. 


\begin{abstract}
This work had as research object the Vocational Gymnasium "Cândido Portinari" (VGCP), public institution of Secondary Education that functioned between the years of 1962 and 1969, in the Batatais city, interior of the State of São Paulo. The objective of this research was to make an institutional history of the VGCP by means of the practical ones constructed by its former-pupils and that they had been cited in its depositions. Such practical had been analyzed through different sources: interviews with former-pupils, photographs of time and institution's documents. This allowed to collate the depositions of the foreseen former-pupils with the practical ones of the institution Pedagogical and Administrative Plans (PAP) and with what was registered in photographs of the experience. Also it was possible to perceive the aspects of the experience that had more marked the former-pupils and the way as these practical had been appropriate for the same ones.
\end{abstract}

Key-Words: Vocational Gymnasium, Practical, Ins titutional History, School Culture. 


\section{LISTA DE FIGURAS}

Figura 1. Construção da Usina Hidrelétrica na fazenda Macaúbas. Fonte: (FERNANDES, 2004, p.36) 59

Figura 2. Estação Fazenda Mogiana. Fonte: (FERNANDES, 2004, p.39). 59

Figura 3. Locomotiva com usuários da Estação Mogiana. Fonte: (FERNANDES, 2004, p.19). 60

Figura 4. Festa junina na Fazenda Macaúbas. Fonte: (FERNANDES, 2004, p.37). 60

Figura 5. Prédio do Ginásio Vocacional "Cândido Portinari” (1962). Fonte: Arquivo do GVCP. 84

Figura 6. Trabalho em Equipe no GVCP: prática constante. 94

Figura 7. Trabalho em Equipe no GVCP: grupos de trabalhos mistos. 94

Figura 8. Estudo do Meio no GVCP: visita à fazenda de café. 95

Figura 9. Estudo do Meio no GVCP: visita à fábrica de calçados, na cidade de Franca. 96

Figura 10. Aula de Datilografia no GVCP. 97

Figura 11. Cooperativa no GVCP. 97

Figura 12. Acampamento do GVCP: montagens das tendas. 98

Figura 13. Acampamento do GVCP: chegada ao local. 99

Figura 14. Governo Estudantil: momento de eleição. 100

Figura 15. Governo Estudantil: entrega de título de eleitor. 100

Figura 16. Governo Estudantil: votação. 101

Figura 17. Economia Doméstica no GVCP: aulas de culinária. 102

Figura 18. Economia Doméstica no GVCP: lavando louça. 102

Figura 19. Economia Doméstica no GVCP: cuidar de crianças. 103 


\section{LISTA DE TABELAS}

Tabela 1 - Matrículas no Ensino Secundário, no Município de São Paulo. 44

Tabela 2 - Número de Ginásios segundo o ano de criação, no Município de São Paulo. 44

Tabela 3 - Número de alunos por ano no GVCP. 89

Tabela 4 - Idades de meninos e meninas da 1ª . série do GVCP (1967 a 1969). 90

Tabela 5 - Profissões dos pais dos alunos do GVCP (1967 a 1969). 92 


\section{LISTA DE SIGLAS}

SEV - Serviço do Ensino Vocacional

PPA - Planos Pedagógicos e Administrativos dos Ginásios Vocacionais do Estado de São Paulo

GVCP - Ginásio Estadual Vocacional "Cândido Portinari”

AESP - Arquivo do Estado de São Paulo

CEDIC - Centro de Documentação e Informação científica "Prof. Casemiro dos Reis Filho" $-\mathrm{PUC} / \mathrm{SP}$

NIEPHE - Núcleo Interdisciplinar de Estudo e Pesquisa em História da Educação - FE/USP 
SUMÁRIO

\section{Introdução}

Capítulo 1 . Construindo o Objeto

1.1. Estado da arte: Ginásios Vocacionais do Estado de São Paulo 19

1.2. Problematizando as Fontes

1.3. História Institucional, Práticas e Cultura Escolar

\section{Capítulo 2 . História dos Ginásios Vocacionais 39 do Estado de São Paulo}

2.1. O Ensino Secundário no Brasil e em São Paulo nos anos de 39 1950 a 1960

2.2. Ginásios Vocacionais do Estado de São Paulo

2.2.1. Implantação e Extinção das experiências vocacionais

2.3. Implantação do GVCP de Batatais

2.3.1. Batatais: a cidade e a educação

\section{Capítulo 3. Ginásio Vocacional "Cândido}

\section{Portinari"}

3.1. Planos Pedagógicos e Administrativos

3.2. Localização

83

3.3. Organização e Funcionamento

85

3.4. Público Alvo

87

3.5. As Práticas no GVCP 


\section{Introdução}

interesse pelo tema "Ginásios Vocacionais" surgiu quando cursava

Pedagogia e em várias disciplinas discutíamos os problemas da educação brasileira tais como: "fracasso", "evasão", "má qualidade de ensino", "péssimas condições de formação e de trabalho do professor", entre outros. A abordagem de tais problemas me incomodava, pois parecia que estávamos num beco sem saída, porque no curso não eram tratadas também as propostas educacionais que tiveram êxito em sua implementação.

Com essa inquietação iniciei, na Faculdade de Educação da Universidade de São Paulo (FE-USP), um levantamento das experiências educacionais desenvolvidas no Estado de São Paulo nas décadas de 1950 e 1960 e, para minha surpresa, havia muitas: Escola "Caetano de Campos", Escola de Aplicação da Universidade de São Paulo, Ginásios Vocacionais e Classes Experimentais. Entre elas, a que mais me chamou a atenção foi a dos Ginásios Vocacionais, por ser embasada em um projeto renovador para o ensino público secundário e prezar pela atuação da família e da comunidade. Interessou-me, também, analisar os motivos pelos quais os militares abortaram a experiência no ano de 1969.

A partir daí comecei uma revisão bibliográfica buscando levantar pesquisas publicadas sobre essa experiência, encontrando três estudos e um documento ${ }^{1}:$ 1) As Cinzas $e$ a Brasa: Ginásios Vocacionais. Um estudo sobre o processo de ensino-aprendizagem na experiência pedagógica do Ginásio Estadual Vocacional Oswaldo Aranha (1962/1969) de Esméria Rovai; 2) Uma Pedagogia para o Trabalhador: o Ensino Vocacional, base para uma proposta pedagógica de capacitação profissional de trabalhadores desempregados (Programa Integrar CNM/CUT) de Maria Nilde Macellani, 3) o trabalho de Ângela Tamberlini, Os Ginásios Vocacionais: a Dimensão Política de um Projeto Pedagógico Transformador; e o documento denominado: Planos Pedagógicos e Administrativos dos Ginásios Vocacionais do Estado de São Paulo do ano de 1968.

\footnotetext{
${ }^{1}$ Discutiremos adiante esses trabalhos de forma pormenorizada, apresentando as contribuições dessas pesquisas para a construção do meu objeto de estudo e como suporte para as análises aqui apresentadas.
} 
O contato com esses trabalhos possibilitou elaborar a primeira versão do projeto que apresentei ao programa de pós-graduação da FE-USP, o qual visava verificar as contribuições dos Ginásios Vocacionais para a educação no Estado e São Paulo. O objetivo era muito amplo para ser desenvolvido no curto prazo do mestrado e para reelaborar o projeto iniciei uma extensa revisão bibliográfica sobre o tema.

Em consulta às bibliotecas tanto da Faculdade de Educação da USP quanto a da Pontifícia Universidade Católica de São Paulo (PUC), obtive a informação de que a proposta dos Ginásios Vocacionais havia sido implantada em seis cidades do Estado de São Paulo, inclusive na capital. Dos trabalhos consultados, verifiquei que quase todos abordaram a experiência do Ginásio Estadual Vocacional “Oswaldo Aranha”, localizado no Brooklin, na cidade de São Paulo, e que fizeram também menção a outras pesquisas sobre o assunto.

No primeiro levantamento encontrei os trabalhos de Tamberlini (1998), Mascellani (1999) e Balzan (1973). Dessa maneira, continuei a investigação das experiências Vocacionais por meio das informações de quatro unidades (Rio Claro, Barretos, São Caetano do Sul e Batatais), que foram contempladas nos trabalhos que analisava até o momento.

A opção pelo Ginásio Vocacional "Cândido Portinari” $(\mathrm{GVCP})^{2}$ da cidade de Batatais ocorreu após esse primeiro levantamento, no qual identifiquei a quase ausência de trabalhos específicos sobre essa escola. Com novas informações coletadas, reelaborei o projeto e apresentei a nova proposta que delimitava como principal objetivo fazer uma história institucional do Ginásio Vocacional "Cândido Portinari” via depoimentos orais dos ex-alunos e analisar suas contribuições para a educação brasileira.

Para iniciar a análise do objeto proposto, participei de diversas atividades, ao longo do curso de mestrado, que me auxiliaram no desenvolvimento da pesquisa. Como experiências variadas entre lugares de interlocução, cursei as disciplinas do programa ${ }^{3}$, participei de monitorias ${ }^{4}$ no Programa de Aperfeiçoamento do Ensino (PAE). Participei ativamente do Núcleo Interdisciplinar de Estudo e Pesquisa em História da Educação

\footnotetext{
${ }^{2}$ Cabe informar que no decorrer do trabalho utilizamos a sigla "GVCP", que corresponde ao objeto desse estudo.

${ }^{3}$ As disciplinas: "Inconsciente, Oralidade e Es crita: aproximações entre ciências da linguagem, psicanálise e ensino" (prof. Claudemir Belintane), "Memória e História da Profissão Docente” (profa. Denice Catani), "A Viragem Lingüística e o Relançamento do Ofício Historiográfico" (p rof. Jorge Ramos do Ó), "Metodologia do Ensino Superior" (profa. Myriam Krasilchik) e "História da Educação: Arquivos e Fontes" (profas. Diana Vidal e Maurilane Biccas).

4 Participei da etapa de Estágio Supervisionado em Docência do Programa de Aperfeiçoamento de Ensino na disciplina EDF 283 "Introdução aos Estudos da Educação", ministrada pela profa. Maurilane de Souza Biccas.
} 
$(\mathrm{NIEPHE})^{5}$. Atualmente a equipe desenvolve o Projeto "As múltiplas estratégias de escolarização do social em São Paulo (1770-1970): cultura e prática escolares", organizado em torno de dois subprojetos principais: "Múltiplas estratégias de escolarização da infância", liderado pela Profa. Dra. Diana Gonçalves Vidal, e "Múltiplas estratégias de escolarização de adolescentes e adultos", liderado pela Profa. Dra. Maurilane de Souza Biccas, que contam com apoio do CNPq (Bolsa Produtividade em Pesquisa e Universal). É nesse subprojeto que a minha pesquisa, financiada pela Capes foi desenvolvida.

Durante essa pesquisa consultei os acervos do Centro de Memória na FE$\mathrm{USP}^{6}$ e do $\mathrm{CEDIC}^{7}$ na PUC-SP, que possibilitaram formular a seguintes perguntas: Quem eram os alunos? Como ingressavam na escola? Quem eram seus professores? Como eram as aulas? Como era o cotidiano no Vocacional?

Essas questões, somadas a um primeiro trabalho de campo realizado na cidade de Batatais, resultaram em uma terceira reformulação do projeto, com redefinição dos objetivos apresentados anteriormente.

No exame de qualificação, a pesquisa tomou um outro rumo e passou a ter como eixo central a história institucional analisada com base nas práticas escolares relatadas pelos ex-alunos e complementadas com outras fontes como: legislação, fotografia, jornais, documentos produzidos pelos Vocacionais e pelo Serviço do Ensino Vocacional - SEV, entre outras. O que busco compreender e analisar são as práticas desenvolvidas para e pelos exalunos, além de investigar também se essas foram apropriadas ou não pelos alunos. Outro aspecto a ser investigado refere-se à especificidade do programa do GVCP. Tudo isso acabou por nortear o objetivo desta pesquisa, que é fazer a história institucional do GVCP da cidade de Batatais mediante práticas construídas para e pelos alunos e que foram referenciadas em suas entrevistas. Essas práticas serão analisadas por meio do PPA e de fotografias da experiência.

\footnotetext{
5 O NIEPHE, "Núcleo Interdisciplinar de Estudo e Pesquisa em História da Educação", compõe-se por pesquisadores provenientes das áreas de Educação, Hstória e Psicologia, que atuam em diferentes níveis: Iniciação Científica, Mestrado, Doutorado e Pós-Doutorado, coordenado pelas Profas. Dras. Diana Vidal e Maurilane Biccas da FE/USP - Faculdade de Educação da Universidade de São Paulo. Para maiores detalhes consultar: www.usp.br/niephe.

${ }^{6}$ O Centro de Memória da Educação (CME-FEUSP) é um órgão da Faculdade de Educação da Universidade de São Paulo que foi criado em 1993. O CME é um espaço elaborado para o desenvolvimento de pesquisas, reunião de documentos e também para integrar os trabalhos de seus membros no campo da História da Educação Escolar no Brasil.

${ }^{7}$ CEDIC é um Centro de Documentação e Informação Científica que recebeu o nome de "Prof. Casemiro dos Reis Filho" e fica localizado na Pontifícia Universidade Católica, em São Paulo.
} 
No Arquivo do Estado de São Paulo - AESP - levantei os jornais da cidade de Batatais e encontrei a "Folha de Batatais" publicada de 1962 a 1969, ou seja, no mesmo período de criação e extinção dos Vocacionais. Porém, as publicações desse jornal nos anos de 1963 a 1965 não constavam no arquivo.

Na cidade de Batatais localizei várias fontes distintas sobre a experiência do Vocacional implantado resta cidade. Em visita ao antigo prédio onde funcionou o GVCP, hoje Escola Estadual "Cândido Portinari", tive acesso aos livros de matrícula dos anos de 1967 a 1969 e ao livro do ano letivo de 1962 a 1969. Entretanto, não encontrei os livros de matrícula dos anos de 1962 a 1966. No O Jornal, localizei as edições do período (1962-1969). Essa fonte foi importante para completar as informações sobre a cidade nos anos de 1960.

Além das visitas citadas, também foram realizadas nove entrevistas com exalunos que fizeram parte da $1^{\mathrm{a}}$ e $2^{\mathrm{a}}$ turma do GVCP. Nestas entrevistas tive acesso aos seguintes documentos deste Vocacional: "Regimento Interno" e "Objetivos dos Acampamentos".

Assim, todo esse manancial de documentos encontrados fez com que o trabalho ganhasse maior proporção, pois além das entrevistas, contava agora com jornais, documentos do GVCP e fotografias, fontes fundamentais para fazer a história dessa instituição.

A dissertação está estruturada em três capítulos. O capítulo inicial traz uma revisão bibliográfica das pesquisas e estudos sobre os Ginásios Vocacionais, que denomino de "Estado da Arte". O estudo dessas produções contribuiu para a configuração do meu objeto de pesquisa. Nesse capítulo procuro ainda discutir as fontes e o referencial teórico que sustentam as análises produzidas sobre o Ginásio Vocacional "Cândido Portinari”.

O segundo capítulo está estruturado em três partes. Na primeira abordo o Ensino Secundário no Brasil e em São Paulo nos anos de 1950 a 1960. Em seguida, trato dos Ginásios Vocacionais do Estado de São Paulo. Na última parte, procuro apresentar a implementação do projeto do Ginásio Vocacional na cidade de Batatais. A finalidade desse capítulo é fazer uma breve apresentação do Ensino Secundário no Brasil, especificamente, no Estado de São Paulo no contexto dos anos de 1950 a 1960, a fim de compreender a forma como foi gestada a proposta dos Ginásios Vocacionais no Estado e na cidade de Batatais.

O terceiro capítulo aborda os Planos Pedagógicos e Administrativos dos Ginásios Vocacionais do Estado de São Paulo (PPA) e o GVCP no que se refere a sua localização, organização, funcionamento, público alvo e as práticas vivenciadas por seus alunos. 
Finalizando esta dissertação, apresento as considerações finais da pesquisa, seguidas das referências bibliográficas utilizadas. 



\section{Capítulo 1 \\ Construindo o Objeto}

ste capítulo está estruturado em três partes: a primeira trata de um
breve estado da arte sobre o tema "Ginásios Vocacionais", indicando como o objeto dessa pesquisa foi configurado. A seguir, é feita uma problematização das fontes que foram trabalhadas e na terceira e última parte, buscou-se fazer uma discussão em torno da História Institucional, Práticas e Cultura Escolar.

\subsection{Estado da Arte: Ginásios Vocacionais do Estado de São Paulo}

O estado da arte que será apresentado foi construído a partir de um levantamento de todos os estudos e pesquisas que se teve acesso, produzidas nos últimos trinta anos. Estas pesquisas são compostas de três teses, cinco dissertações e três livros desenvolvidos em diversas áreas: Educação, Filosofia, Psicologia e Artes. Porém, nenhum deles foi elaborado no campo da História da Educação e Historiografia. Neste sentido, esperase que este estudo possa ser uma contribuição.

É importante destacar que o estado da arte aqui proposto não segue uma ordem cronológica por datas de produção dos trabalhos, mas sim, uma ordem que indica e acompanha o processo de criação, implantação, organização, funcionamento, crises e extinção dos Vocacionais.

Alice Aguiar de Barros Fontes defende sua tese intitulada: Inovações Educacionais: Autores e Atores das Classes Experimentais, em 1999, na Faculdade de Educação da Universidade de São Paulo. Este trabalho tratou do surgimento e da instalação das classes experimentais no Brasil, fazendo referência às classes nouvelles ${ }^{8}$. A autora chama

\footnotetext{
8 As classes nouvelles ou classes novas foram propostas de educação para o Ensino Secundário que buscavam a adaptação de novas práticas com métodos e organização pedagógica também novos. Esse modelo de ensino procurou ajustar principalmente o Ensino Secundário às imposições do que chamavam de mundo moderno.
} 
a atenção para o modo como os educadores brasileiros compreenderam esse modelo escolar francês, e que segundo Fontes, acabaram por influenciar a criação do Serviço do Ensino Vocacional (SEV) ${ }^{9}$.

Para desenvolver suas análises, Fontes (1999) trabalhou com os acervos pertencentes ao $\mathrm{CEDIC}^{10}$ e ao SEV, na cidade de São Paulo. Os documentos que consultou foram do Conselho Estadual de Educação, além de depoimentos da coordenadora, de professores, alunas, funcionários e do diretor do Instituto de Educação de Jundiaí em 1965, época em que esta instituição era escola experimental.

O trabalho de Fontes (1999) apresenta o projeto das classes experimentais que tinha como característica salas ambiente criadas para estimular o processo de aprendizagem dos alunos. A proposta também tinha como pressuposto a interação da escola com a comunidade e o estudo do meio passou a ser uma importante estratégia pedagógica para esta finalidade. Pode-se perceber uma semelhança entre o projeto das classes experimentais e o que viria a ser o Ensino Vocacional.

Das contribuições desse trabalho para esta pesquisa, devemos ressaltar dois aspectos. Um primeiro que compreende o mapeamento feito pela autora das bases teórica, filosófica e política que levaram possivelmente outros autores e sujeitos da educação a pensar na criação das classes experimentais e que, posteriormente, inspirariam à criação dos Ginásios Vocacionais. Um segundo aspecto diz respeito ao modo como Fontes (1999) descreve o processo de implantação das classes experimentais, a inspiração, a essência e a origem de idéias que fundamentaram a criação dos Vocacionais.

Ângela Rabello Maciel de Barros Tamberlini defende sua dissertação denominada: Os Ginásios Vocacionais: A Dimensão Política de um Projeto Pedagógico Transformador $^{11}$, em 1998, na Faculdade de Educação da Universidade de São Paulo.

Tamberlini (1998) apresenta em seu trabalho os contextos econômico, cultural, político, filosófico e educacional que caracterizam a época dos Vocacionais. A autora também se preocupou em fazer uma descrição da proposta pedagógica do Ensino Vocacional, procurando reconstituir as relações dos participantes desse ensino com o regime militar e o

\footnotetext{
${ }^{9}$ SEV, Serviço do Ensino Vocacional, criado por meio do artigo 25 da Lei Estadual no. 6.052 de 03 de fevereiro de 1961 e regulamentada pelo Decreto Estadual no. 38.643, art. 302, de 27 de junho de 1961. Ver com mais detalhes em (BALZAN, 1978).

${ }^{10}$ CEDIC, Centro de Documentação e Informação Científica "Prof. Cassimiro dos Reis Filho", da Pontifícia Universidade Católica de São Paulo PUC/SP.

${ }^{11}$ Essa pesquisa de Ângela R. M. de Barros Tamberlini foi publicada pela editora Annablume no ano 2000, o livro recebe o mesmo título de sua pesquisa de Mestrado.
} 
governo estadual. Esse aspecto em especial nos dá indícios da extinção da experiência na medida em que Tamberlini (1998) procura examinar as tensões existentes entre a proposta dos Vocacionais, a sociedade e o governo estadual.

Para sua investigação, a autora usou fontes documentais pertencentes ao CEDIC como: artigos, teses, documentos e textos referentes à experiência Vocacional. Quanto às publicações do SEV, analisou as leis e os decretos referentes à criação dos Ginásios Vocacionais e seu regimento interno. Também recorreu às fontes orais e contou ainda com alguns depoimentos existentes na tese de Rovai (1996). Além disso, as fontes por ela levantadas e analisadas contribuíram para a ampliação da presente pesquisa e a localização de outros documentos que foram fundamentais para a construção deste trabalho.

Sobre a criação dos Vocacionais na esfera educacional, Tamberlini (1998) afirma que "[...] a criação legal dos Ginásios Vocacionais foi viabilizada por um gesto habilidoso do Secretário Estadual de Educação, que aproveitou uma brecha da Lei do Ensino Industrial para possibilitar a existência legal desse novo tipo de escola”. Já na esfera federal, “[...] a partir da promulgação da LDB, em dezembro de 1961, os Ginásios Vocacionais passaram a se fundamentar no artigo 104, da referida Lei” (p.44-5).

Um dos pontos essenciais apresentados em sua pesquisa é a questão da instalação das escolas Vocacionais no Estado de São Paulo. A autora aponta que a instalação de cada unidade escolar '[...] foi precedida de uma pesquisa de campo para, ao se estudar a realidade local, ser possível planejar o currículo apropriado para aquela comunidade" (TAMBERLINI, 1998, p.51). Ou seja, que os elementos considerados no currículo necessariamente teriam de estabelecer uma relação entre escola e comunidade local, além de levar em conta a realidade da cidade e, por conseguinte, de sua população. Essa pesquisa contribuiu para uma maior compreensão do que foi a experiência dos Ginásios Vocacionais no que se refere a sua proposta educacional.

A preocupação em trazer um modelo pedagógico em conformidade com a realidade social aparece na tese de Maria Nilde Mascellani intitulada: Uma Pedagogia para o Trabalhador: O Ensino Vocacional como Base para uma Proposta Pedagógica de Capacitação Profissional de Trabalhadores Desempregados (Programa Integrar ${ }^{12}$ CNM/CUT), defendida em 1999, na Faculdade de Educação da Universidade de São Paulo.

A autora tomou como foco para esse estudo duas propostas pedagógicas que estiveram sob sua coordenação, "Programa Integrar" e "Ginásios Vocacionais Noturnos",

\footnotetext{
12 O Programa Integrar foi um projeto de capacitação para trabalhadores desempregados coordenado por Maria Nilde Mascellani, na época docente da PUC/ São Paulo. Para saber mais detalhes, ver (MASCELLANI, 1999).
} 
comparando as fundamentações das duas propostas. Também analisou suas semelhanças e diferenças, sobretudo quanto à organização institucional e aos componentes pedagógicos e políticos, concluindo que:

Enquanto os Ginásios Vocacionais noturnos surgiram como uma resposta, por parte do Estado à demanda de escolarização dos segmentos de baixa renda, o Programa Integrar responde a uma proposta encampada diretamente pela sociedade civil, através da CNM-CUT, para qualificar e requalificar operários desempregados, com preferência para ex-metalúrgicos. Os dois programas, cada um a seu modo, procuram responder à questão social - a marginalização dos trabalhadores entre outras razões, pela falta de escolarização (MASCELLANI, 1999, p.296).

Outro fator importante é a estrutura das duas experiências, que segundo afirma Mascellani (1999):

No caso do Programa Integrar, a estrutura organizacional e funcional é extremamente precária, e isso não se deve apenas ao seu menor grau de institucionalização ou mesmo ao seu tempo de duração, evidentemente menores, quando comparados ao do Ensino Vocacional. A nosso ver, a diferença essencial registra-se no modo de compreensão das dimensões pedagógica e política nos dois projetos. Em ambos os casos, os projetos tiveram uma base pedagógico-política bem definida. Entretanto, enquanto os Ginásios Vocacionais noturnos faziam do processo pedagógico sua ferramenta principal para o desenvolvimento da cidadania, o Programa Integrar dicotomiza essas dimensões, considerando-as de modo separado. $\mathrm{O}$ Ginásio Vocacional noturno trabalhava a política através da educação, até porque não há educação que não seja política. O Programa Integrar, em contrapartida, define o político pelo sindical e, neste sentido, considera que o pedagógico não necessita ser aperfeiçoado, porque o objetivo maior está na ação política dos sindicatos. Isto trará consequiências importantes do ponto de vista organizacional (p.300).

Essa tese foi composta com depoimentos de ex-alunos do "Programa Integrar" e de ex-alunos, professores, diretores, orientadores pedagógicos educacionais e também de pais que haviam participado ativamente dos Ginásios Vocacionais Noturnos. Foram consultados ainda relatórios, planejamentos, leis, decretos e portarias. Essa pesquisa, além de trazer informações sobre o projeto dos Ginásios Vocacionais Noturnos, apresenta um número considerável de fontes que a autora reuniu após o término da experiência para fins de pesquisa no CEDIC. 
Entre as diversas contribuições que a pesquisa de Mascellani (1999) traz para este estudo, destacam-se os aspectos analisados por ela referentes à construção de um projeto pedagó gico que de fato considere a demanda e a realidade social na qual está inserido.

Esméria Rovai ${ }^{13}$ defendeu sua tese: Um Estudo sobre o Processo de EnsinoAprendizagem na Experiência Pedagógica do Ginásio Estadual Vocacional Oswaldo Aranha, em 1996, na Pontifícia Universidade Católica de São Paulo. Seu trabalho buscou mostrar a:

[...] implementação prática da proposta pedagógica do Ensino vocacional, através da experiência ocorrida na unidade do Ginásio Estadual Vocacional "Oswaldo Aranha"14 tomando como eixo o processo de ensinoaprendizagem alí desenvolvido (ROVAI, 1996, p.8).

Rovai (1996) aborda o projeto para o Ensino Vocacional, no qual se encontram descritas as diversas práticas de seu currículo, tais como: estudo do meio, trabalho em grupo, cantina, cooperativa, ação comunitária e outras. A autora busca investigar quais são as representações que os sujeitos têm da experiência Vocacional e, para tanto, contou com depoimentos de ex-alunos, professores, diretor, membros da equipe técnica, pais e da excoordenadora do SEV.

Um dos questionamentos feitos por Rovai (1996) é se o modelo dos Ginásios Vocacionais era uma proposta repetível, assegurando que: "A experiência dos vocacionais não é uma experiência passível de repetição. Por sua própria natureza, ela foi e continuará sendo uma proposta sempre suscetível de recriação" (p.617).

Tomando esse questionamento da autora, ocorrem outros relacionados às práticas da escola, tais como: Como essas organizavam o funcionamento dos Vocacionais? Como os alunos se apropriaram dessas práticas? Seriam elas específicas de cada vocacional? Outro fator bastante significativo presente nesta tese e na maioria das pesquisas consultadas é o uso de depoimentos, seja como fonte principal, seja para completar a análise, além do uso dos planos pedagógicos e administrativos dos Vocacionais (PPA).

Uma outra dissertação que revela um pouco a experiência Vocacional na unidade de Rio Claro, é a de Sandra Machado Lunardi Marques, intitulada: Contribuição ao Estudo dos Ginásios Vocacionais do Estado de São Paulo: O Ginásio Vocacional Chanceler

\footnotetext{
13 A profa. Esméria Rovai, trabalhou no GVCP de 1962-1966, responsável pelo setor de audiovisual, sendo uma de suas funções, registrar e acompanhar as atividades dentro e fora da escola. Após esse período Rovai segue para a cidade de São Paulo, desenvolvendo o mesmo trabalho no Ginásio Vocacional "Oswaldo Aranha", onde permanece até o fim da experiência em 12 de dezembro de 1969.

14 O Ginásio Estadual Vocacional “Oswaldo Aranha” também era conhecido pela sigla GEVOA.
} 
Raul Fernandes de Rio Claro, defendida em 1985, na Faculdade de Educação da Pontifícia Universidade Católica de São Paulo. A autora teve como objetivos construir a memória histórica do Ginásio Vocacional "Chanceler Raul Fernandes" e recuperar algumas de suas práticas por meio de depoimentos orais do corpo docente, técnico e administrativo, criando assim subsídios para se repensar o ensino público. Analisou ainda as características pedagógicas e administrativas do Ensino Vocacional, explicitando sua intencionalidade em se tornar uma escola comunitária.

Marques (1985) abordou a criação, o funcionamento e também o papel da Associação de Pais e Amigos do Vocacional de Rio Claro. Segundo a autora, a equipe de cada Vocacional mobilizou as Sociedades de Pais e Amigos dos Vocacionais no sentido de angariar benefícios para a continuidade da experiência. Além disso, menciona que houve várias tentativas, por parte dos pais, para que fosse instalado o segundo ciclo Vocacional na unidade de Rio Claro. Para tanto, foi elaborado e publicado um comunicado '[...] no jornal Diário de Rio Claro para que dirigentes do comércio, da indústria, de entidades educacionais, religiosas e civis enviassem ofícios ao governador pedindo a nstalação do segundo ciclo vocacional" (MARQUES, 1985, p.101).

A respeito desse envolvimento dos pais, comunidade e escola, a autora observa que :

As relações entre pais e mestres das várias unidades dos ginásios vocacionais já estavam suficientemente sedimentadas por confraternizações, encontros de pais e festivais de corais e conjuntos instrumentais. A finalidade e constância desses encontros geraram entre os participantes sentimentos de ligação muito fortes a ponto deles se identificarem como "família vocacional' (MARQUES, 1985, p.104 e 108).

É possível compreender como a família e a comunidade eram mobilizadas pela equipe do Ensino Vocacional a participar da vida da escola e da própria comunidade.

Dos trabalhos que tratam mais especificamente da experiência dos Vocacionais nas cidades de Barretos e Batatais, chamamos a atenção para a dissertação de Margarida Góes de Araújo Pinho, denominada: Ensino de Artes Plásticas nos Ginásios Estaduais Vocacionais (1962-1969), defendida em 1983, na Escola de Comunicação e Arte (ECA) da Universidade de São Paulo. A autora foi professora de Artes Plásticas nos Vocacionais de Barretos e Batatais e priorizou nesse trabalho analisar sua experiência em Barretos pelo fato de ser natural dessa cidade. Mas essa escolha não impediu que ao longo de seu trabalho trouxesse a lume aspectos importantes de sua prática realizada no Vocacional de 
Batatais. A autora discute as Artes Plásticas como área do conhecimento e de que maneira esta área foi trabalhada dentro do projeto pedagógico do Vocacional. Para isso, utilizou uma bibliografia específica sobre o tema Artes Plásticas, além de analisar os relatos de todos os participantes da experiência por ela desenvolvida nos dois Ginásios Vocacionais.

Um dos aspectos destacados pela autora refere-se ao modo como se ensina artes, e argumenta que essa prática de ensino pode ocorrer em todas as escolas públicas que têm uma concepção de currículo flexível. No caso específico das Artes Plásticas, enfatiza que podem ser realizadas em qualquer lugar, independentemente das condições oferecidas pelas regiões onde os Vocacionais estão localizados. De acordo com sua idéia:

O meio e os representantes artísticos que a ela [cidade] pertenciam é que determinavam que tipo de arte inicialmente deveria ser valorizada: a do artesão, como ocorreu em Barretos, a do artista industrial ou das artes aplicadas como aconteceu em Americana, ou do artista do tipo "artes maiores", como aconteceu em Batatais e Rio Claro [...] Isso provou que se poderia ensinar arte e ensiná-la bem, oferecendo ainda uma vivência artística sem se sair de sua região, valorizando e descobrindo o patrimônio que ela [cidade] possuía e com isso dando a oportunidade para que novos talentos se manifestassem (PINHO,1983,p.183).

É possível perceber quanto se explorava da cultura das cidades para o desenvolvimento de uma educação para a arte. Sua dissertação, assim como a tese de Balzan (1973) possibilitam compreender o funcionamento do currículo, que pareceu ser um instrumento flexível na sua utilização.

A tese de Newton César Balzan denomina-se: Estudos Sociais: Opiniões e Atitudes de Ex-Alunos, foi defendida em 1973, na Faculdade de Filosofia, Ciências e Letras da (UNESP) de Presidente Prudente. O autor discute e retoma sua experiência no período de (1962 a 1966), como professor de Estudos Sociais no Ginásio Vocacional "João XXIII", na cidade de Americana, utilizando as fontes orais para avaliar o processo de aprendizagem na área em que atuou. Balzan (1973), por meio das fontes orais, buscou identificar o processo de aprendizagem em Estudos Sociais. Procurou saber se o conteúdo dessa área teria sido adquirido ou modificado pelos alunos durante a experiência no Vocacional, em seus cursos universitários, em suas profissões e nos seus momentos de lazer.

Para tanto, fez entrevistas com seus ex-alunos de primeira a quarta séries do Ensino Vocacional na forma de questionário e concluiu que dos três anos em que esteve como supervisor da área, '[...] a avaliação realizada em Estudos Sociais tenha sido suficientemente válida, dizendo respeito ao desempenho global do aluno" (BALZAN, 1973, p.76). 
É importante destacar que a área de Estudos Sociais era o eixo central da proposta curricular dos Ginásios Vocacionais e que Balzan (1973) procurou questionar seus alunos sobre essa proposta curricular e também se esta pode ter vindo ajudá-los ou até prejudicá-los em suas escolhas e inserção no campo profissional. Sobre esse questionamento Balzan (1973) constatou que:

O ex-aluno valoriza Estudos Sociais e não se julga prejudicado pela posição dada à área de Estudos Sociais no Ginásio Vocacional; ao mesmo tempo, a grande ênfase dada a Estudos Sociais, segundo 133 dos 116 ex-alunos, não os prejudicou posteriormente (p.117).

O autor além de mostrar a importância dada pelos alunos sobre Estudos Sociais, faz indagar: Como esses sujeitos construíram suas memórias sobre a experiência? O que levou esses sujeitos (ex-alunos) a reconhecerem o Vocacional como um centro formador de pessoas críticas, capazes de intervir no meio social em que estão inseridos? Tais perguntas dirigem o olhar para a questão da memória e seu processo de (re)construção.

Em 2002, Ary Meirelles Jacobucci publica seu livro intitulado: Revolucionou e Acabou? Breve Etnografia do Ginásio Estadual Vocacional de Americana: Geva ${ }^{15}$. Este é um outro estudo que vem colaborar para a história dos ginásios vocacionais tratando especificamente do Vocacional de Americana. Jacobucci é um ex-aluno do Ginásio Vocacional "João XXIII" que utilizando as memórias de alguns participantes da experiência, tenta reconstruir nessa obra o contexto histórico, político e pedagógico que permitiu a criação e a extinção do Vocacional de Americana.

Esse trabalho traz informações importantes para compreender as motivações para a criação dos Vocacionais, nesse caso especifico de Americana em que destaca as articulações políticas existentes por traz das definições dos locais onde essas instituições seriam implantadas.

Jacobucci (2002) aponta há semelhanças entre a proposta dos Ginásios Vocacional à da Escola Nova ${ }^{16}$. Entretanto, Rovai (2005) faz uma crítica a esse tipo de afirmação dizendo que:

\footnotetext{
15 O título deste livro é o mesmo da dissertação de Mestrado do autor, defendida em 2000, no Centro Universitário Salesiano de São Paulo (UNISAL).

${ }^{16}$ O movimento da Escola Nova no Brasil aconteceu na década de 30, quando em 1932 foi divulgado o "Manifesto dos Pioneiros da Escola Nova". Esse documento foi elaborado no intuito de defender a gratuidade, laicidade, obrigatoriedade e um Plano Nacional de Educação. Seu foco central estava na discussão em torno da qualidade e das práticas de ensino, além da luta pela democratização do acesso à educação.
} 
O projeto, porém, de forte inspiração no novo humanismo, centrado no homem concreto, volta-se ao homem brasileiro e contempla a formação integral do educando, o seu autoconhecimento e a descoberta da vocaçãa ${ }^{17}$, entendida em seu sentido mais amplo como a pessoa que se realiza no mundo em suas relações socioculturais - hoje diríamos uma construção sócio-histórica -, tendo no trabalho, como um fazer e um fazer-se, um princípio mediador (p.18-9).

Sobre os fatores que contribuíram para a extinção dos Vocacionais, Jacobucci (2002) destaca que o fechamento dessas escolas ocorreu por conflitos existentes entre governo e educadores do Vocacional. O governo considerou essa experiência como subversiva e sobre isso o autor afirma que '[...] não foi circunstancial que, em 1969, auge repressivo da ditadura militar, os Ginásios Vocacionais fossem extintos, denominados subversivos" (p.83).

A dissertação que dá mais visibilidade às questões do fim da experiência é a de Daniel Ferraz Chiozzini intitulada: A (Dês) Construção História de Uma Experiência Educacional Transformadora (1961-69), defendida em 2003, na Universidade de Campinas(UNICAMP). Esse trabalho fez uma análise histórica dos Ginásios Vocacionais investigando suas origens, contradições, crises internas e externas. $\mathrm{O}$ autor, além de fazer um estudo bibliográfico sobre a educação no período, investigou os Anais da Assembléia Legislativa do Estado de São Paulo e consultou os debates legislativos em torno da aprovação da lei que criou os Ginásios Vocacionais.

O autor também contou com depoimentos do professor Newton Balzan já mencionado anteriormente e da profa. Da.Olga Bechara que foi orientadora pedagógica do Ginásio Vocacional de Americana, São Paulo, e do SEV.

Chiozzini (2003) organizou sua pesquisa em duas partes. A primeira é uma análise sobre as origens das escolas Vocacionais diante de alguns referenciais teóricos que estavam em evidência na década de 60. A segunda consiste na verificação das crises que o vocacional enfrentou desde o início de sua trajetória e como elas colaboraram para o seu fim.

Esméria Rovai organizou o livro Ensino Vocacional. Uma pedagogia atual, em 2005. Uma obra recente sobre o tema configura-se em uma contribuição para a História da Educação no Estado de São Paulo na medida em que os autores, que em sua maioria vivenciaram, pesquisaram e estudaram o Ensino Vocacional, dialogam sobre suas

\footnotetext{
${ }^{17}$ A noção de vocação no Ensino Vocacional tem forte influência do Humanismo Integral de Emanuel Mournier, como a vocação de ser homem que personaliza suas ações, através de um processo permanente de opções. Para isso, ver Rovai, E, op. cit, p. 43.
} 
experiências faze ndo um paralelo com o atual ensino público. Essa obra tem por finalidade fundamentar:

[...] o debate de temas candentes que estão postos para a educação pública brasileira: a organização do ensino fundamental que supere a seriação e a avaliação do ensino-aprendizagem que melhor traduza o processo educativo e prescinda de provas unificadas de múltipla escolha para "medir" sua qualidade (ROVAI, 2005, p.9).

O livro documenta a experiência do Ensino Vocacional apresentando os escassos recursos principalmente, financeiros e físicos enfrentados pela equipe Vocacional durante o período mais duro no Brasil, que foi a revolução de 1964. Além disso, o livro vem contribuir para se pensar na educação brasileira, nas metodologias e técnicas pedagógicas. Este livro como os estudos anteriormente apresentados não esgotam toda a história dessa experiência Vocacional, mas deixam muitas questões a serem respondidas ou no mínimo, aprofundadas.

Além dos artigos que Rovai assina junto com outros autores e o que encerra o livro, essa obra é composta de um total de oito artigos assim nomeados: "Os Ginásios Vocacionais, a História e a Possibilidade de Futuro" de autoria de Ângela R.M.de Barros Tamberlini; "Uma Pedagogia Social em Ato - Revivida na Memória" de Esméria Rovai; “Avaliação Emancipatória nos Ginásios Vocacionais” de Esméria Rovai e Nobuko Kawashita; "A Formação Continuada do Professor Centrada na Escola - A Experiência do Ginásio Vocacional" de Moacyr da Silva; "Vocacional: um Projeto para o Século XXI" de Newton César Balzan; "Notícias dos Anos de Vocacional” de Aureliano Biancharelli; "Ainda sonhamos" de Paulo Ricardo Simon; e "Um Encontro com o Passado Pensando o Futuro" de Esméria Rovai.

A obra foi construída por dois alunos, dois professores, um orientador pedagógico, uma orientadora educacional e uma pesquisadora do tema. Pareceu-nos que a memória de homem, mulher, aluno, professor, orientador(a) se constitui nos textos como elemento fundador na construção dessa história do passado escrita no presente, pelo fato de o Vocacional ter sido vivido e analisado por meio de lugares, perspectivas e tempos diferentes.

Enfim, toda essa bibliografia levantada, consultada e analisada até o momento possibilitou ter uma noção mais aproximada da criação, da organização, do funcionamento e da extinção desse projeto dos Ginásios Vocacionais do Estado de São Paulo. 
Esta primeira parte desse capítulo, em que se buscou produzir um breve estado da arte, ajudou a pensar a organização e a elaboração desta dissertação com base em três grandes aspectos: tema, fonte e Vocacionais pesquisados.

O primeiro aspecto, tema "Ginásios Vocacionais", foi trabalhada segundo quatro abordagens distintas. Uma primeira trata esta temática enquanto política pública de inovação para o Ensino Secundário. É o caso dos trabalhos de Masselani (1999), Rovai (2005), Jacobucci (2002) e Tamberlini (1998). Em uma segunda abordagem, tem-se a análise do projeto pedagógico do Ensino Vocacional via disciplinas (Arte Plásticas, Estudos Sociais), que são os casos de Pinho (1983) e Balzan (1973). Em uma terceira abordagem, Rovai (1996), trata do processo de ensino-aprendizagem e, finalmente, a dimensão política do projeto, o próprio projeto e as crises enfrentadas pelos Vocacionais são abordados por Tamberlini (1998), Mascellani (1999), Marques (1985) e Chiozzini (2003).

Quanto ao segundo aspecto, toda essa incursão pelos trabalhos publicados serviu para conhecer as fontes já utilizadas (depoimentos, entrevistas e documentos sobre a instituição) e ampliar seu espectro por meio de fotografias e jornais. Percebe-se, ainda, que os depoimentos foram usados em quase todos os trabalhos que compôs a revisão bibliográfica produzida. Isso mostra que o fato de a experiência ter sido abortada pela ditadura militar fez com que documentos escritos fossem destruídos, perdidos e dispersos. Este fato configura um dos aspectos relevantes dessa pesquisa. Passados quase 40 anos do término da experiência Vocacional, sem o temor de represarias pela sua divulgação, documentos antes guardados começam a serem disponibilizados para pesquisas. É a partir desses documentos que esse trabalho foi construído.

A produção de documentos escritos por meio de entrevistas é às vezes a única possibilidade de reconstituir e analisar o que foi esta experiência. Assim, os trabalhos abordados foram extremamente significativos, pois se acredita que as pesquisas reiteram o Vocacional como um lugar de memória e também como a memória de um lugar, na medida em que para tratar o tema os autores retomam o tempo todo praticamente a mesma bibliografia e as mesmas fontes.

$\mathrm{O}$ terceiro e último aspecto, referente às pesquisas que trataram de Vocacionais específicos, acabaram por informar quais unidades foram objeto de estudo, o que possibilitou afirmar que o Ginásio Vocacional "Cândido Portinari”, da cidade de Batatais, não foi, até então, foco de investigação. 
Por este motivo, optou-se neste trabalho por tratar especificamente da experiência ocorrida em Batatais. As questões que merecem ser respondidas no âmbito dessa investigação são:

- Quais as motivações políticas e pedagógicas que definiram essa cidade como lugar importante para os desenvolvimentos de tal modelo educacional?

○ Quais os critérios de ingresso de alunos?

$\circ$ Quem foram os alunos dessa escola?

○ Qual o perfil dos pais?

- Diante dos sujeitos que compunham o GVCP, como se dava a participação dos alunos, professores, pais e comunidade na elaboração desse projeto e seus planos de ação comunitária?

○ Quais as práticas que caracterizam a experiência do GVCP?

\subsection{Problematizando as Fontes}

No Brasil, muito recentemente, fazer História da Educação é mais do que somente fazer a história do ensino. Isso significa que os estudos sobre História da Educação não se limitam apenas à história das instituições escolares, do pensamento pedagógico, de movimentos educacionais, entre outros. Nesse sentido, observa-se uma ampliação das temáticas até então não abordadas nos trabalhos realizados dentro do campo da historiografia educacional, o que significa ampliar e rever as fontes sob um novo olhar, possibilitando novas análises. Tal perspectiva teórica denominada de Nova História Cultural também considera outros sujeitos como, por exemplo, mulheres, meninos/meninas, alunos/alunas, negros, asiáticos entre outros. Quanto aos temas que são recorrentes nesse campo, podemos destacar: escola, família, profissão docente, alfabetização, currículo, saberes escolares e arquitetura escolar.

O enfoque dado ao objeto também varia, trazendo novos questionamentos que apontam as possíveis fontes capazes de investigá-lo. Outro aspecto importante é o trabalho crítico do pesquisador com as fontes, centrando suas discussões em torno delas e fazendo-as "falar" ou estabelecer um "diálogo" com o objeto. Esse processo constitui-se num fazer História da Educação, pois que as fontes compõem materiais históricos com que os 
pesquisadores podem contar em suas investigações. Assim é que, segundo Nunes (1993), passa-se de pedagogo a historiador, porque o primeiro " [...] ganha a distância necessária para olhar de uma nova maneira a pedagogia, tornando-se, pela sua prática e pelo seu projeto, um historiador" (p.23).

Nesse sentido, além de refletir sobre as fontes, o pesquisador deve estar atento à localização do arquivo que consulta, sua conservação e manutenção feita pelas instituições que o mantêm, sendo isso que caracteriza seu trabalho nesse campo. E aqui nos reportamos a Certeau (1994) quando diz que “[...] em história, tudo começa com o gesto de separar, de reunir, de transformar em documentos' certos objetos distribuídos de outra maneira" (p.81).

Pode-se afirmar que o trabalho com as fontes constitui uma das maiores dificuldades que o historiador enfrenta, porque exige optar por abordagens teóricas as quais lhe garantem uma forma de operar com as fontes que, independentemente do conjunto de documentos ou até mesmo na ausência deles, configuram o trabalho.

Ainda assim, a escolha das fontes está ligada diretamente à História Cultural pela quantidade de opções que esta dispõe aos pesquisadores, pela diversidade de objetos e problemas sobre eles e também pela ampliação das concepções do documento como fonte histórica e expressão de uma cultura. São esses novos elementos da historiografia, sobretudo da chamada Nova História Cultural, que permitem tomar um distanciamento dos enfoques tradicionais da História da Educação.

Quando se trata de pesquisas relacionadas aos Ginásios Vocacionais, como é percebido no estado da arte feito anteriormente, outros desafios são apresentados pelos autores que investigam ou investigaram o tema. Por exemplo, a ausência das fontes e, por conseguinte, o uso freqüente de entrevistas na maioria dos trabalhos. Esse fato está diretamente relacionado ao processo de extinção dessas escolas: todas as unidades foram invadidas pelos militares que recolheram documentos e materiais pedagógicos, restando apenas "Cinzas e Brasas" 18 da experiência.

De todo o acervo dos Vocacionais, restaram apenas alguns documentos pertencentes ao Serviço do Ensino Vocacional e também aqueles que foram "salvos/recuperados" por professores, pais e funcionários em razão das ameaças, e que foram

\footnotetext{
${ }^{18}$ Título do trabalho de Esméria Rovai (1996) utilizado para representar o que aconteceu com os documentos da experiência.
} 
recolhidos e organizados por Mascellani, alguns anos depois, quando era docente da PUC/SP. ${ }^{19}$

$\mathrm{Na}$ presente pesquisa, além de fazer uso do documento pertencente ao CEDIC (PPA), também se recorreu a jornais, documentos, fotografias, publicações sobre o tema e entrevistas. Nessa perspectiva, o uso destas visará complementar e também dar inteligibilidade às informações.

A fonte impressa, no caso os jornais (que também são fontes históricas), possibilita-nos, segundo Grazziontini (2006), entrar no universo que compreende as relações pessoais e políticas da região, perceber as representações de tomadas de posição de proporções tanto macro e micro da região estudada. No entanto, ao trazer dados dessa fonte para a pesquisa, é preciso considerar alguns fatores: “[...] a história do periódico, o posicionamento político dos dirigentes, donos, ou chefe da redação" (p.4). E o pesquisador, caso não tome um distanciamento levando esses fatores em consideração, correrá o risco de fazer uma falsa análise, pois cada fonte exige um conhecimento sobre sua especificidade e uma forma de trabalhar singular.

Ao mesmo tempo em que as fontes se ampliam, cresce também a problematização sobre a "natureza e validade das mesmas". Para Romancini (2005), '[...] a idéia de o documento portar uma 'verdade' é questionada, sendo esta atitude substituída por outra, mais ativa em termos de crítica e reflexão frente à documentação coletada" (p.4).

E semelhante a isso é o modo como manipulamos os dados para fazermos as análises desses documentos. No caso deste trabalho, as fontes impressas usadas foram: a revista "Batatais - A Cidade dos Mais Belos Jardins" (FERNANDES, 2004), os jornais 20 "A Folha de Batatais" (dos anos de 1961, 1962, 1966 e 1967) e "O Jornal" (de 1969) e os livros ${ }^{21}$ "Batatais, a sua evolução histórica" e "Outrora Batatais", de 1997 e 1998, respectivamente.

Dos documentos produzidos pelo Ensino Vocacional foram usados os livros de matrículas dos anos de 1967 a 1969 do GVCP, o Regimento Interno do Acampamento, o Relatório do RENOV ${ }^{22}$, o PPA ${ }^{23}$ do ano de 1968 e fotografias. Todos esses documentos foram

\footnotetext{
${ }^{19}$ Esse trabalho de recolher os documentos que restaram das exp eriências culminou em dois fundos localizados no CEDIC e denominados SEV e RENOV.

${ }^{20}$ É importante informar que o período pesquisado dos jornais foi de 1960 a 1970 , e nesse período não foi encontrado em nenhum dos arquivos de Batatais e nem do AESP em São Paulo, esses jornais publicados nos anos de 1963 e 1964.

${ }^{21}$ Esses livros foram organizados pela Secretaria da Cultura de Batatais e pelo Museu Histórico Washington Luis, organizado por Barbieri, um historiador da cidade de Batatais, durante a administração mu nicipal de período de 1997-2000.

${ }^{22}$ Esse relatório, denominado "Extratos de Uma Experiência Educacional”, foi elaborado no ano de 1968 pela
} 
elaborados durante a experiência. Logo, importa questionar: Como esses documentos foram construídos? Quem os organizou? Para quais finalidades? Para onde e para quem foram encaminhados?

Em Batatais, m sede provisória do "Amigos Para Sempre”, uma associação de ex-alunos do GVCP localizada em um cômodo do estabelecimento comercial de uma de suas ex-alunas, há um acervo de aproximadamente cem fotos deste Vocacional, uma parte organizada em álbuns e outra parte avulsa guardada em caixas. Tais fotografias foram tiradas pela profa. Esméria Rovai, responsável pelo setor de áudio-visual da unidade.

No tocante ao tratamento do acervo fotográfico do GVCP, considerou-se que "[...] o registro visual documentado, e [...] a própria atitude do fotógrafo diante da realidade de seu estado de espírito e sua ideologia acabam transparecendo em suas imagens" (KOSSOY, 2000, p.42-43). Por isso, o documento fotográfico deverá ser interpretado, partindo também do pressuposto de que a imagem fotografada foi, em primeiro lugar, uma escolha do fotógrafo e que a imagem congelada nesse documento fotográfico não pode ser interpretada sem antes levar em consideração o processo de construção das representações que a gerou. A imagem fotográfica é assim o ponto de partida do processo investigativo, porque ela não se esgota em si mesma. Toda e qualquer imagem fotográfica revela um fragmento, ou seja, uma parte do que foi escolhido para ser visto por alguém.

Lembrando Vidal (1998), “[...] refletir sobre fotografia como fonte requer um esforço para superar a atração exercida pela imagem e pensá-la enquanto fonte documental ultrapassando sua qualidade meramente ilustrativa" (p.73). Porém, tais considerações fogem do objetivo deste trabalho e não serão aprofundadas aqui.

Assim como a fonte impressa, outra fonte importante para o desenvolvimento desta pesquisa foram as publicações (livros, dissertações e teses) sobre o tema "Ginásios Vocacionais". Essas fontes secundárias foram analisadas tomando-se o mesmo distanciamento mencionado anteriormente.

Outra fonte utilizada neste trabalho foram os depoimentos transcritos de exalunos do GVCP. Nove ex-alunos foram entrevistados, cinco homens e quatro mulheres. Desses, sete ingressaram na primeira turma (1962) e dois na segunda (1963). De todos eles, apenas um não possuíam curso superior. Quando a idade, três deles estavam com 55, três com 56 e um com 58 anos. Para o processo de coleta de depoimentos, foi elaborado inicialmente

equipe da RENOV.

${ }^{23}$ Não utilizamos o PPA de outros anos pelo fato de não termos encontrado nos arquivos que consultamo s. 
um roteiro composto por quinze questões abertas, aplicadas na forma de entrevistas gravadas. Dos nove ex-alunos, cinco foram entrevistados duas vezes para esclarecimentos de relatos incompletos da primeira entrevista.

A utilização da história oral como método e a entrevista transcrita como fonte permitiram fazer uma história do tempo presente, pois cada depoimento, segundo Vidal (1990), tem uma tripla temporalidade: é o vivido, o lembrado e o narrado. O primeiro referese ao que já passou. O segundo, é a memória viva e o terceiro é aquele que acontece no momento da entrevista.

Há que se considerar também que os discursos são sempre vestígios das práticas. Assim, procurou-se analisar as transcrições das entrevistas observando tanto o conteúdo quanto a forma como os depoimentos se (re)constroem. Neste trabalho é imprescindível saber que:

A memória coletiva e a sua forma científica, a história, aplicam-se a dois tipos de materiais: os documentos e os monumentos. Esses materiais da memória podem apresentar-se sob duas formas principais: os monumentos, herança do passado, e os documentos, escolha do historiador (LE GOFF, 1984, p.95).

É possível compreender o GVCP como um monumento, pois tanto os documentos escritos quanto os orais são documentos históricos. Segundo Vidal (1990), o uso desses "monumentos" "[...] podem oferecer de subsídios à compreensão do passado e do que este passado se tornou no presente" (p.82). Dessa forma, as memórias são subsídios, uma vez que são sempre "representações" que evidenciam alguns aspectos do passado investigado.

É em tal direção que esta pesquisa foi desenvolvida, pensando no contexto em que tanto os documentos ${ }^{24}$ quanto os discursos dos alunos do GVCP foram gerados, na maneira e na finalidade para as quais foram construídos, pois que:

[...] o documento oral, o testemunho, forma-se no momento da entrevista, no diálogo estabelecido entre o entrevistador e o entrevistado. Portanto, é o produto da interação desses dois sujeitos que emerge como conteúdo a ser, posteriormente, analisado pelo historiador (VIDAL, 1990, p.80).

\footnotetext{
${ }^{24}$ Estamos compreendendo os documentos como: “(...) uma montagem, consciente ou inconsciente, da história, da época, da sociedade que os produzem, mas também das épocas sucessivas durante as quais continuou a viver, talvez esquecido, durante as quais continuou a ser manipulado, ainda que pelo silêncio. O documento é algo que fica, que dura, e o testemunho, o ensinamento (...) que ele traz devem ser em primeiro analisados desmistificando-lhe o seu significado aparente" (LE GOFF, 1984, p. 104).
} 
Com o intuito de compreender o processo acima, será preciso problematizar as fontes, desmistificá-las. Pois cada fonte buscará evidenciar a realidade que interessa mostrar, gerando assim diferentes histórias da experiência.

Cabe investigar também, nesse caso, até que ponto os depoimentos não estariam dando voz '[...] a experiências vividas por indivíduos e grupos que foram excluídos das narrativas históricas anteriores, ou foram marginalizados" (THOMPSON, 1997, p.69). Essa é uma que stão relevante, porque também nos remete a outra que é: Esses documentos sobre a experiência não estariam revelando apenas as representações dos sujeitos sobre essa história? Porque no caso das lembranças ou memórias desse período, como explica Halwachs (1998):

[...] as lembranças podem ser chamadas de representações, na medida em que repousam sobre a memória de experiências e racionalização feitas a partir destas, permitindo-lhe reatualizar-se constantemente com base na permanência de situações significativas nas quais o seu sentido pode ser ainda conservado (p.71-2).

Assim, se consideramos que essas memórias, ou melhor, esses documentos são representações da experiência, isso nos leva a entender que não haverá somente uma única memória da experiência Vocacional, mas muitas pois somos eternos construtores do nosso passado.

A maneira como recuperamos e divulgamos nossas reminiscências diz muito sobre o modo como construímos nossas identidades, e isso significa que pode haver tantas memórias quantos grupos existirem. Nesse sentido concordo com Halbwachs (1998) quando diz: “Ora, há em cada época uma estreita relação entre os hábitos, o espírito de um grupo e o aspecto dos lugares onde ele vive [...]" (p.69), porque memória e identidade são também construções que reforçam nossas imagens.

Sobre essa mesma questão, Pollak (1992) afirma que:

[...] a memória é um elemento constituinte do sentimento de identidade, tanto individual como coletiva, na medida em que ela é também um fator extremamente importante do sentimento de continuidade e de coerência de uma pessoa ou de um grupo em sua reconstrução de si (p.204).

E segundo Samuel (1994): 
[...] a memória longe de ser meramente um receptáculo passivo ou um sistema de armazenagem, um banco de imagens do passado, é, isto sim, uma força ativa, que molda: que é dinâmica - o que ela sintomaticamente planeja esquecer é tão importante quanto o que ela lembra - e que ela é dialeticamente relacionada ao pensamento histórico, ao invés de ser apenas uma espécie de seu negativo (p.44).

Desse modo, parece pertinente pensar nos Ginásios Vocacionais, como um lugar capaz de preservar a memória da experiência, vivida por alguns partícipes, no caso, os alunos. É sabido que o ato de rememorar implica escolher o que lembrar e como lembrar, pois poucos são os momentos em que pensamos sobre as memórias que escolhemos para recordar e qual sentido atribui a elas. Menos ainda, somos capazes de perceber que nossas identidades são construídas por essas memórias.

Assim, na tentativa de responder as questões e dar prosseguimento à investigação é que serão apresentadas no item a seguir algumas categorias que auxiliaram nesta pesquisa.

\subsection{História Institucional, Práticas e Cultura Escolar ${ }^{25}$}

Quando se trata de fazer História da Educação numa perspectiva da história institucional, é importante discutir as práticas que conformam a cultura escolar, ou seja, os modos de funcionamento que nos permitem ver o interior da escola. Mas no trabalho com as práticas deve-se atentar, reportando à Certeau (1994), para o aspecto problemático da “enunciação", justamente por lidar com prescrições das práticas e não com elas [práticas] em si.

Embora acreditando que tanto o GVCP como os demais Vocacionais instituíram uma forma singular de organização dos sujeitos, dos espaços, do tempo, podemos dizer que produziram uma "cultura escolar" própria e para defini-la melhor usaremos o termo no singular conforme Faria Filho, que articula a noção de cultura escolar e a de escolarização, colocando em evidência as práticas, a relação da escola com a sociedade e os saberes escolares. Para o autor, a cultura escolar:

\footnotetext{
${ }^{25}$ Nesta pesquisa, optou-se pelo conceito de cultura escolar por ser um recurso que, além de ampliar o enfoque sobre o universo escolar, também usa como categoria de análise as práticas escolares.
} 
"[...] permite articular, descrever e analisar, de uma forma muito rica e complexa os elementos chave que compõem o fenômeno educativo tais como os tempos, os espaços, os sujeitos, os conhecimentos e as práticas escolares" (FARIA FILHO, 2002, p 16-7).

Nesse movimento de direcionar o olhar para os sujeitos (ex-alunos), é possível compreendê-los como integrantes de uma cultura escolar que junto de outros sujeitos escolares, professores, por exemplo, não só colocam em funcionamento a instituição ou cultura que freqüentam como também se (re)produzem como sujeitos sociais que trabalham na construção da escola e da cultura escolar.

Segundo Faria Filho et al. (2004), fazer um estudo acerca das "práticas" é um caminho para a investigação do funcionamento interno da escola, uma vez que essa categoria tem aparecido com freqüência como campo de investigação e como categoria de análise nas pesquisas em História da Educação.

Assim, apropriou-se do termo para construir a história institucional do GVCP por essa via, uma vez que as práticas trazidas neste trabalho são as evocadas pelos ex-alunos, que analisadas e comparadas com outras fontes, oferecem alguns elementos da cultura escolar desse Vocacional. 



\section{Capítulo}

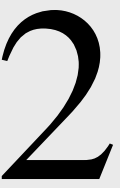

\section{História dos Ginásios Vocacionais de São Paulo}

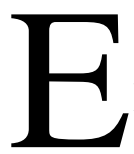

ste capítulo está estruturado em três grandes tópicos: o primeiro, o

Ensino Secundário no Brasil e em São Paulo nos anos de 1950 e 1960; o segundo, Ginásios Estaduais Vocacionais do Estado de São Paulo, sua implantação e extinção. Nesse tópico, tratar-se sobre as classes experimentais no esforço de perceber a importância dessa experiência na formação dos Ginásios Vocacionais. Em seguida, em um terceiro tópico, é abordada a implantação do GVCP, a cidade de Batatais e a educação. Para isso, fez-se uso dos documentos produzidos no GVCP e também no SEV.

A finalidade deste capítulo é, além de mostrar o contexto educacional no Brasil, especificamente no Estado de São Paulo, investigar sobre os possíveis motivos que a cidade de Batatais apresentou para receber uma unidade Vocacional.

\subsection{O Ensino Secundário no Brasil e em São Paulo nos anos de 1950 a 1960}

Uma referência importante abordando a formação do Ensino Secundário no Brasil é o texto: $O$ "velho" e "bom" ensino secundário: momentos decisivos de Clarice Nunes.

Nunes (2000) inicia seu texto com uma discussão a cerca do surgimento dos colégios de Ensino Secundário, colocando-os como produtos da missão dos Jesuítas no Brasil e de sua política de separação entre o ensino de humanidades, destinado aos filhos dos colonos mais abastados, e o ensino destinado aos indígenas, voltado preponderantemente para a catequese.

De acordo com a autora, esses colégios foram iniciativas que representaram uma forma escolar com um objetivo bem definido: a educação da elite. Essa concepção 
permaneceu no país, mesmo com a República, até a promulgação da nossa primeira Lei de Diretrizes e Bases da Ed ucação Nacional, em 1961.

Do período do Império até o século XX, o modelo de escola para o Ensino Secundário que predomina é o do Colégio Pedro II, posteriormente denominado Ginásio Nacional, com o advento da República. Esta escola tornourse o equivalente público de um Ensino Secundário considerado de qualidade junto à elite. Seus formandos encontravam as portas de qualquer faculdade do Império abertas, independentes das provas.

A estrutura do secundário modifica-se no período da República com Francisco $\operatorname{Campos}^{26}$ no ministério da Educação, que afirma a função educativa desse ensino.

Nesse período há toda uma discussão se este ensino seria somente uma ponte para a Universidade, e é nesse momento que Campos eleva o Ensino Secundário para sete anos, dividindo-o em dois ciclos:

[...] o primeiro, de cinco anos, denominado curso secundário fundamental, e o segundo, de dois anos, chamado de complementar, subdividido em três especialidades que correspondiam a um dos três grupos de cursos superiores: engenharia e agronomia; medicina, odontologia, farmácia e veterinária; direito (NUNES, 2000, p.44).

Porém, a reforma Gustavo Capanema ${ }^{27}$, vigente de 1942-1962, que antecede a reforma de Francisco Campos de 1931, ao opor o ensino primário e profissional e o secundário e superior, já afirmava aí a dualidade do ensino. Com a criação das Leis Orgânicas, Capanema reestrutura o secundário ao lado de outras leis orgânicas que regularam os ensinos industrial, comercial, agrícola e normal. Essa lei permanece em vigor até a LDB de 1961. Essas leis organizaram o secundário da seguinte forma:

[...] num primeiro ciclo, chamado de Ginásio (secundário, industrial, comercial e agrícola) e num segundo ciclo, que na Reforma Francisco Campos estivera subdivido em três, passava a constituir-se em dois cursos

\footnotetext{
${ }^{26}$ Francisco Luís da Silva Campos ingressou na política como deputado estadual pelo PRM. Foi também deputado estadual; deputado federal; Secretário do Interior; ministro da Educação (1930/1932), preocupando-se essencialmente com o ensino superior e secundário; Consultor-Geral da República (1933/1937); Ministro da Justiça (1937/1941). Como ministro da justiça, redigiu a Carta de 1937, que instaurou o Estado Novo. Colaborou ativamente na elaboração das leis autoritárias, após a derrubada do governo João Goulart. Ver (FAUSTO, 1997).

${ }^{27}$ Gustavo Capanema, Ministro da Educação e Saúde entre os anos de 1934 a 1945, foi um dos responsáveis pela reorganização do ensino no Brasil. Em 1937 encaminha ao Congresso o Plano Nacional de Educação. Em 1942, em pleno Fstado Novo, Capanema inicia as reformas de ensino que foram traduzidas nas chamadas "leis orgânicas do ensino".
} 
que não apresentavam do ponto de vista curricular qualquer caráter de especialização (NUNES, 2000, p.44).

Outro fator importante a destacar nesse contexto é a atuação do SENAI (Serviço Nacional de Aprendizagem Industrial), uma entidade representativa do empresariado industrial criada pelo Decreto de no.4.048/42, e do SENAC (Serviço Nacional de Aprendizagem Comercial), criado pelos Decretos-Leis 8.621 e 8.622 e subordinado ao empresariado comercial.

Aqui tem-se uma questão importante. No caso do técnico, de mão de obra qualificada para o mercado interno, esses serviços são criados com uma perspectiva na linha de que o país precisava se desenvolver. Neste sentido, a estrutura do Ensino Secundário precisaria ser revista. De acordo com Francisco Campos, a finalidade do Ensino Secundário:

[...] deve ser a formação do homem para todos os grandes sectores da actividade nacional, construindo no seu espírito todo um systema de habitos, attitudes e comportamentos que o habilitem a viver por si mesmo e a tomar em qualquer situação as decisões mais convenientes e mais seguras. [...] A educação do homem não se fará jamais mediante o systema de receptividade passiva, pelo qual se vem degradando, no ensino secundário, a intelligencia da juventude. A massa de conhecimentos, posta á disposição do alumno, já preparada, cozida e digerida não contribuirá para o desenvolvimento das qualidades nobres do julgamento e do criterio, qualidades activas e dynamicas, que lhe servirão na vida para identificar as novas situações em que se encontra, modificalas utilizalas e dar-lhes a solução apropriada. (CAMPOS, 1941, p.47-8)

No caso de São Paulo, o processo de extensão dos anos de escolaridade proposta por Francisco Campos junto a um "[...] maior número de habitantes e a gradativa eliminação das desigualdades sociais na organização formal do sistema escolar" constituiu o denominado processo de democratização do ensino. Iniciada em 1945,

[...] a ampliação dos estabelecimentos ginasiais só alcança ritmo mais intenso em meados da década de 50, período configurado como a gênese da extensão das oportunidades de acesso ao ensino ginasial na cidade de São Paulo (SPÓSITO, 1992, p.15-6).

Nunes (2000) aponta que no período entre o Estado Novo e o regime militar de 1964, foi intensa a participação da população urbana, sobretudo das classes média e operária, na reivindicação por uma '[...] educação escolarizada, transformando a abertura de ginásios públicos em bandeira de luta nas Câmaras estaduais e municipais”. Sobre a criação 
dos ginásios, outro dado trazido pela autora é que a '[...] região sudeste em comparação com as demais regiões do país era a mais beneficiada em termos de educação secundária" (p.46).

Segundo Beiseigel (2002), no caso de São Paulo, a questão da demanda social decorre a partir da década de 1940, devido ao período de expansão urbana, da transformação do mercado de trabalho, com:

[...] progressiva multiplicação de oportunidades de emprego nas burocracias das empresas públicas e privadas, a passagem pela escola começava a ser compreendida pelas populações urbanas como o principal recurso de ascensão social para os filhos. Até então, esse tipo de escola era mantido quase que exclusivamente por entidades privadas, leigas e confessionais. Mas com o crescimento da procura entre significativos contingentes da população urbana que não tinham recursos para o pagamento das anuidades do ensino privado, as pressões sobre a oferta concentravam-se agora sobre o Governo do Estado. Encampadas pelos políticos que disputavam o voto popular, essas reivindicações provocaram intenso processo de criação das escolas secundárias públicas estaduais. Em 1945 e 1962, foram criadas 516 escolas secundárias oficiais na rede escolar estadual. A mudança nesse setor de ensino, foi intensa, rápida e perturbadora (p.3-4).

Segundo Spósito (1992), após a expansão dos ginásios em São Paulo, executada por Jânio Quadros, na época chefe do Executivo,

[...] a Secretaria da Educação enviou ao Gabinete do Governador uma proposta que depois é transformada em Decreto, prevendo a instalação de Cursos Intensivos de Preparatórios a Exame de Admissão em todos os estabelecimentos (ginásios) da rede estadual de ensino. A realização desses cursos, pode ser caracterizada como uma dentre outras iniciativas que buscavam abrir os cursos ginasiais a um contingente maior de população até então excluídas desse nível de escolaridade (p.65).

Por algumas décadas, a linha divisória entre o ensino primário e secundário foi o exame de admissão. Tal exame agravava a seletividade do Ensino Secundário pelo fato de as escolas não terem vagas e também por não divulgarem seus programas, deixando pais e alunos sem saber se o nível de exigência das provas era compatível com o nível de conteúdo da $4^{\text {a }}$ série das escolas primárias. Desse modo, o exame de admissão:

[...] mobiliza os estudantes, seus pais e irmãos. Obter a aprovação nas provas tinha uma importância equivalente à aprovação nos exames vestibulares ao ensino superior. Era uma espécie de senha para a ascensão social (NUNES, 2000, p.45). 
Em razão do grande crescimento urbano-industrial de São Paulo ao longo da década de 1950, Jânio Quadros, conforme afirma Hilsdorf(2003), aplicou:

[...] um conjunto de mecanismos apresentados como circunstancial e provisório [...] e quanto ao ensino secundário [...] adotou mecanismos de aprovação compulsória de $80 \%$ dos alunos matriculados nos ginásios e nas escolas normais, para desocupar as vagas para novos alunos; criação de escolas normais e ginásios noturnos; instalação de "secções", ou seja, extensões dos ginásios tradicionais, que passaram a funcionar em prédios de grupos escolares ou de escolas privadas, configurando um verdadeiro derramamento de escolas secundárias acadêmicas em todo o Estado. (p.115)

Os debates do período enfocam tanto a expansão quanto a própria função do secundário. No Brasil, particularmente, discutia-se que esse ensino deveria:

[...] acompanhar esta onda de mudança rapidamente, porque era extremamente de dentro da escola que surgiria este homem de ação: psicoativado, mas autônomo. Ele deveria ter um aprendizado múltiplo, dinâmico, que exigisse uma maior mobilidade, ou melhor dizendo, aceleração, da mente e do corpo, até porque, caso contrário, tornar-se-ia ineficaz, atrasado, e por fim, cairia no discurso do lento, contemplativo, obsoleto, "velho" (BRAGHINI, 2005, p.72).

A escola deveria acompanhar as mudanças que a sociedade brasileira estava sofrendo. Essa discussão girava em torno do "velho" e do "novo" na educação ${ }^{28}$, e o que estava em jogo, sobretudo, era a questão da qualidade do ensino, especificamente do secundário, era a polarização em torno de um ensino religioso ou laico, assim como a descentralização e outras questões lançadas pelo movimento da Escola Nova.

Em São Paulo, os anos de 1957 e 1958 foi um período de ampliação das redes de ensino com cerca de 90 ginásios criados (ver Tabelas 1 e 2). Isso ocorreu em razão da inexistência de escolas secundárias públicas, e também particulares, que levou parte da população a reivindicar "a criação de ginásio estadual para sua cidade" (SPOSITO, 1992, p.16-29).

No final dos anos 1950, com essa expansão do secundário no país, na cidade de São Paulo acontece a '[...] 1 $1^{\mathrm{a}}$. Jornada de Diretores do Ensino Secundário, realizada em 1957 sob os auspícios da Inspectoria Seccional local, solicitava o funcionamento de classes experimentais, o que viria a ser concretizado dois anos mais tarde" (NUNES, 2000, p.49).

\footnotetext{
${ }^{28}$ As referências (FONSECA, 2004; NUNES, 2002; XAVIER, 2001 e WEREBE, 1960 apud BRAGHINI,2005) discutem em seus trabalhos o choque entre o novo e o velho no ensino secundário.
} 
Em 1959, ocorreu a campanha em favor da escola pública, também conhecida como o segundo "Manifesto dos Pioneiros", elaborado por Fernando de Azevedo ${ }^{29}$. Esse documento defendia princípios como um ensino laico, gratuito, obrigatório e um Plano Nacional de Educação.

Tabela 1 - Matrículas no Ensino Secundário, no Município de São Paulo.

\begin{tabular}{|c|c|c|}
\hline Ano & Ensino Público & Ensino Particular \\
\hline $\mathbf{1 9 4 7}$ & 2.672 & 40.516 \\
\hline $\mathbf{1 9 6 0}$ & 36.758 & 53.130 \\
\hline $\mathbf{1 9 7 0}$ & 257.591 & 85.033 \\
\hline
\end{tabular}

Fonte: (SPÓSITO, 1992, p.46).

Tabela 2 - Número de Ginásios segundo o ano de criação, no Município de São Paulo.

\begin{tabular}{|c|c|}
\hline Ano & Número de Criações \\
\hline $\mathbf{1 8 9 2}$ & 1 \\
\hline $\mathbf{1 9 3 3}$ & $2^{30}$ \\
\hline $\mathbf{1 9 4 5}$ & 7 \\
\hline $\mathbf{1 9 4 8}$ & 1 \\
\hline $\mathbf{1 9 4 9}$ & - \\
\hline $\mathbf{1 9 5 0}$ & 1 \\
\hline $\mathbf{1 9 5 1}$ & 3 \\
\hline $\mathbf{1 9 5 2}$ & 8 \\
\hline $\mathbf{1 9 5 3}$ & 3 \\
\hline $\mathbf{1 9 5 4}$ & 2 \\
\hline $\mathbf{1 9 5 5}$ & 1 \\
\hline $\mathbf{1 9 5 6}$ & 1 \\
\hline $\mathbf{1 9 5 7}$ & 25 \\
\hline $\mathbf{1 9 5 8}$ & 36 \\
\hline Total & $\mathbf{9 1}$ \\
\hline
\end{tabular}

Fonte: (SPÓSITO, 1992, p.47).

Ainda no ano de 1958, no seio de intensa mobilização social, é que o Parecer no.77/58, referente ao Instituto de Classes Experimentais, é aprovado. Esse modelo,

\footnotetext{
${ }^{29}$ Fernando de Azevedo nasceu em São Gonçalo do Sapucaí (MG), em 2 de abril de 1894. Bacharelou-se em Direito, pela Faculdade do Largo de São Francisco (SP), em 1918. De 1923 a 1926, foi redator e crítico literário do Jornal "O Estado de São Paulo", onde presidiu os inquéritos sobre Arquitetura Colonial Brasileira e sobre Educação Pública. Iniciou em 17 de janeiro de 1927 a direção da Instrução Pública do Distrito Federal (RJ), nela permanecendo até outubro de 1930. Com a Revolução de outubro de 1930, Azevedo voltou a São Paulo, encerrando a sua gestão da educação na capital do Brasil. No Estado de São Paulo, Fernando de Azevedo ocupou a Secretaria da Educação e Saúde em 1947 e a Secretaria de Educação e Cultura no governo do prefeito Prestes Maia, em 1961. Maiores informações, ver (VIDAL, 2000).

${ }^{30}$ Anexos às escolas normais.
} 
depois incorporado e também adaptado pelos Vocacionais, parece ser mais um esforço no que se refere à renovação do Ensino Secundário paulista, por apresentar um modelo renovado ou moderno de educação voltado para a formação do homem integral.

O Ensino Vocacional apresentou uma proposta pedagógica cheia de intenções democratizadoras, que foi adaptada em função das diversas realidades em que foi implantada.

\subsection{Ginásios Estaduais Vocacionais do Estado de São Paulo}

O modelo dos ginásios vocacionais foi fruto de inspirações e experiências educacionais desenvolvidas dentro e fora do País. Uma das experiências que mais influenciaram na criação dessas escolas no Estado de São Paulo foi a das classes experimentais. Segundo Fontes (1999), a idéia deve ter sido gestada no encontro realizado no Consulado Francês em 1950, quando foi convidado um grupo de educadores, entre eles o prof. Luis Contier, na época diretor do Instituto de Educação Alberto Comte em Santo Amaro, no Estado de São Paulo. Este grupo fez um estágio em Sèvres, nas chamadas classes nouvelles ou classes experimentais. De acordo com Fontes (1999), após dois anos de estudo e estágio na França, o professor Contier iniciou na escola em que era diretor, um projeto semelhante ao das classes experimentais, passando então a adaptar algumas das metodologias dessa proposta, que procurava detectar aptidões nas séries iniciais e praticar a orientação Vocacional nos anos seguintes.

Esta experiência sensibilizou o diretor do Ensino Secundário do Ministério da Educação e Cultura (MEC), o prof. Gildásio Amado que teve contato com a proposta da experiência na $1^{\mathrm{a}}$. Jornada, mencionada anteriormente, quando '[...] Luis Contier expôs o trabalho que vinha realizando. A partir daí ele passou a articular a aprovação da portaria do MEC que permitiu que surgissem outras experiências no país” (CHIOZZINI, 2003, p. 48).

E conforme afirma Mascellani (1999):

Após homologação do pedido pelo então ministro Clóvis Salgado, em julho de 1958, era publicada a $1^{a}$ circular da Diretoria de Ensino Secundário, que tinha como conteúdo as "instruções sobre a natureza e a organização das classes experimentais [...]. Em janeiro de 1959 o MEC, por meio da portaria, 
autorizou o funcionamento das "classes experimentais", em nível nacional (p.76).

Uma das primeiras classes experimentais foi implantada na cidade de Socorro no interior do Estado de São Paulo e teve seu embasamento metodológico inspirado no modelo de Sèvres (França), nas propostas da Escola Nova que tinha como idéia central a pedagogia do educador John Dewey ${ }^{31}$. Além desse instituto denominado de Instituto de Educação Narciso Pieroni, foram ainda instalados o '[...] Instituto de Educação de Jundiaí, Instituto de Educação Culto à Ciência, de Campinas, e na capital, nos Institutos de Educação Alberto Comte e Macedo Soares” (MASCELLANI, 1999, p.76).

De acordo com Fontes (1999) as "classes experimentais" foram fundamentais para a criação do que seriam os Vocacionais, cuja iniciativa em São Paulo partiu do então Secretário da Educação do Estado de São Paulo, Luciano Vasconcellos de Carvalho, que trabalhou em favor da implantação de um novo modelo de escola que atendesse às reivindicações de uma sociedade em processo de democratização ${ }^{32}$. Para efetivar essa proposta, foi formada uma comissão de educadores e especialistas do Ensino Secundário e industrial, presidida pelo prof. Oswaldo Barros Santos ${ }^{33}$. Fazia parte dessa comissão a profa. Maria Nilde Mascellani, que desde 1959 trabalhava como professora nas classes experimentais na cidade de Socorro.

Pode-se inferir que as classes experimentais foram um modelo inspirador da iniciativa educacional dos Vocacionais no Estado de São Paulo, muito provavelmente pela participação de pessoas como Mascellani que posteriormente tornou-se orientadora pedagógica das classes experimentais, e Olga Bechara, professora que assumiu a orientação pedagógica no Instituto de Socorro.

O trabalho da comissão da qual Mascellani fazia parte deu origem à lei que criaria as três primeiras unidades dos Vocacionais e também ao SEV, instituído por meio do artigo 25 da Lei Estadual, nº 6052 de 3 de fevereiro de 1961, mais conhecida como Lei do Ensino Industrial. Dos 93 artigos dessa lei, regulamentada pelo Decreto Estadual no 38.643, art. 302, de 27 de Junho de 1961 somente quatro contemplam os cursos Vocacionais.

De acordo com o PPA,

\footnotetext{
31 A questão democrática é um dos principais aspectos da pedagogia desse educado que também inspirou algumas formulações do Ensino Vocacional. Para maiores detalhes ver: (CUNHA, 2001).

${ }^{32}$ Ver (AZANHA, 1993).

${ }^{33}$ Santos foi técnico de Educação do Departamento de Ensino Técnico Profissional.
} 
A referida Lei estabelece no seu artigo 25, parágrafo único, que seria instalado um órgão especializado da Secretaria da Educação para coordenar as unidades de Ensino Vocacional denominadas Ginásios Vocacionais. O decreto No. 38.643 estabelece no seu artigo 302 que o referido órgão é o SEV e lhe atribui a faixa de competência (SERVIÇO DO ENSINO VOCACIONAL, 1968a, p.12).

Quanto ao Ensino Vocacional '[...] tudo indica que o secretário [Luciano Carvalho] conseguiu criar condições para a implantação do Vocacional com o apoio de deputados que eram ferrenhos defensores do ensino tecnicista" (CHIOZZINI, 2003, p.27). Esse autor aborda ainda o parecer da Comissão de Educação e Cultura da Assembléia no qual foi inserido o artigo já mencionado, constando que essa iniciativa:

[...] ia ao encontro de uma proposta pedagógica mais ampla, em que o ensino secundário passaria a oferecer ao indivíduo um leque de possibilidades, sem a preocupação de encaminhá-lo diretamente ao mercado de trabalho, a Universidade ou qualquer outro curso (CHIOZZINI, 2003, p29).

É possível perceber que a elaboração do projeto dos Vocacionais teve a participação e a articulação de pessoas preocupadas em oferecer um ensino que preparasse o jovem para a vida, é o que se pode verificar pelo menos do ponto de vista da lei.

Porém, a viabilização desse projeto contou com o envolvimento significativo da equipe do SEV composta por:

[...] coordenadoria, equipe de assessor-administrativo e pedagógico, equipe de pesquisa, com socióloga, psico-pedagoga, setor de estágios (capacitação pedagógica), setor de despesa, setor de prédios e equipamentos, setor pessoal, setor de relações públicas, setor de audiovisual, documentação e biblioteca (MASCELLANI, 1999, p.89).

Coube a esse órgão especializado e diretamente subordinado ao gabinete do Secretário da Educação do Estado, fazer uma pesquisa na comunidade para obter dados que auxiliariam na composição do currículo dos Ginásios Vocacionais. Aliás, o nome Ginásios Vocacionais foi uma escolha de Luciano Vasconcellos de Carvalho que, segundo Chiozzini (2003), se inspirou “[...] no discurso humanista cristão de pensadores como Emmanuel Mournier" (p.57). O pensamento de Mournier ${ }^{34}$, filósofo humanista e também um dos maiores

\footnotetext{
${ }^{34}$ Segundo apresentado no trabalho Comunitarismo e Educação: Implicações e Limites de Tamberlini (2003, p.75), Mournier não só é um crítico do capitalismo, como se filia à concepção católica de vocação e se identifica com as correntes do socialismo cristão.
} 
representantes do personalismo cristão na França, estava presente em toda a pedagogia dos Vocacionais, cuja prioridade era oferecer:

[...] "orientação vocacional", ou seja, a atitude permanente de acompanhar o jovem, ajudá-lo nas dúvidas e oferecer suporte às suas opções. Assim, uma "Pedagogia Vocacional" ou um "Ensino Vocacional" é aquele que leva o educando a se descobrir, descobrindo o campo de atuação no qual pode identificar a possibilidade de um projeto para a construção de seu próprio futuro (MASCELLANI, 1999, p.103) ${ }^{35}$.

Esse ensino extrapolava os muros da escola por fornecer ao aluno uma formação integral que tocava o plano da cultura geral e da cultura técnica. Tal ensino, segundo Tamberlini (2003), tinha como finalidade prepara o jovem para a cidadania, compromissado com a comunidade em que estava inserido.

A autora também afirma que os Vocacionais foram escolas comunitárias que:

[...] procuravam transformar as comunidades onde agia e atuava, educando não só as crianças, mas também os pais e os membros da comunidade [...] nos finais de semana eram realizados os projetos de ação comunitária, além da abertura da escola aos moradores do bairro, aos quais eram apresentadas peças de teatro, obras de arte, exposição, feiras de livros e outras inúmeras atividades (TAMBERLINI, 2003, p.127).

Esse modelo de escola comunitária contou com a participação da comunidade local, reunindo pessoas e estimulando-as ao engajamento político. Os efeitos desse movimento gerado no interior da escola e vivenciado por professores, alunos, pais e comunidade aparecem muito nos depoimentos dos ex-alunos do GVCP.

É importante destacar que diferentemente das escolas da época, que tinham as orientações comuns a todos os estabelecimentos de ensino do Estado, os Vocacionais tiveram um Regimento Interno ${ }^{36}$ próprio, único e elaborado pela coordenadoria do SEV. Segundo esse documento, o ensino oferecido nos Vocacionais objetivava atender aos moldes de uma escola comunitária, buscando:

[...] preparar [os jovens] para estudos posteriores, também levar alunos, professôres, pais e demais membros da comunidade à compreensão de que a

\footnotetext{
${ }^{35}$ A autora ainda aponta que essa pedagogia “[...] tomava a realidade social como conteúdo, a crítica permanente como metodologia e a transformação social como objetivo" (MASCELLANI, 1999, p.104).

${ }^{36}$ Regimento Interno dos Ginásios Vocacionais. Título I. Dos Objetivos. Itens 03 e 33, do artigo 2º 1968: 1-2 (cópia datilografada do original).
} 
escola deverá ser o centro: a- onde se reunam todos os esforços das famílias que moram a seu redor e cujos filhos a freqüentam; b- onde se faça $o$ processo de integração de grupos através da ação dos educadores, pais e dos próprios alunos; c- para onde convirjam as realizações de outros grupos ou instituições/ e de onde partam os resultados dessa conversão (SERVIÇO DO ENSINO VOCACIONAL, 1968b, p.2).

Para contemplar esses objetivos, a equipe do SEV elaborou os Planos Pedagógicos e Administrativos dos Ginásios Vocacionais (PPA); nesse documento estavam sistematizadas as atividades que viriam ajudar na organização e no funcionamento do Ensino Vocacional no Estado de São Paulo.

\subsubsection{Implantação e Extinção das Experiências Vocacionais}

A instalação dos ginásios deveria seguir as seguintes exigências da Secretaria da Educação: “1) possuir um prédio escolar disponível e sujeito a reformas e ampliação; 2) Índice satisfatório de demanda escolar; 3) parceria com a Prefeitura no tocante ao prédio; 4) aceitação da nova proposta educacional" (MASCELLANI, 1999, p.85).

Quanto à primeira exigência, sabe-se que o processo de instalação e implementação começou a ser gerenciado em 1961 pelo Fundo Estadual de Construção Escolar (FECE) ${ }^{37}$, o qual estudou a disponibilidade de prédios em fase de construção que pudessem ser entregues ao Ensino Vocacional para a instalação das unidades.

Antes das instalações dos Vocacionais, cabia ao Serviço do Ensino Vocacional dar início às Pesquisas de Comunidade. Essas:

[...] incidem, particularmente, sobre a caracterização geral da cidade, as atividades econômicas nela predominantes, a composição de sua população. Ainda num plano mais limitado, [...] levanta-se o nível sócio-econômico desta clientela, suas aspirações e expectativas educacionais, profissionais e de status, além de uma visão do tipo de escola secundária que a comunidade propõe e [...] qual o índice de receptividade de um nôvo tipo de escola, diverso do proposto (SERVIÇO DO ENSINO VOCACIONAL, 1968a, p.32$3)$.

\footnotetext{
${ }^{37}$ A equipe do SEV teve o contato, no ano de 1961, com o FECE (Fundo Estadual de Construções Escolares) que foi responsável por oferecer os prédios onde funcionariam as seis unidades vocacionais no Estado. Mais detalhes ver (SERVIÇO DO ENSINO VOCACIONAL, 1968a, p.14).
} 
As unidades Vocacionais começam a ser instaladas no ano de 1962, com a criação inicialmente do Ginásio Vocacional Oswaldo Aranha, na cidade de São Paulo, Ginásio Vocacional "Cândido Portinari”, em Batatais, e do Ginásio Vocacional João XXIII em Americana.

No caso do Ginásio Vocacional Oswaldo Aranha, ele foi implantado na cidade de São Paulo '[...] num edifício situado na Rua Pensylvania com a Avenida Santo Amaro, no Brooklin Novo, que conservava muitas áreas livres e terrenos sem construção" (MASCELLANI, 1999, p.88).

Sobre a escolha destas cidades consta no PPA:

Foram escolhidos os três locais onde seriam instaladas as primeiras unidades escolares, recaindo a escolha sobre um bairro da cidade de São Paulo (área metropolitana), uma cidade industrial do interior e uma cidade de economia predominantemente agrícola. Assim, o FECE ofereceu um prédio no bairro do Brooklim e promoveu a adaptação e a primeira fase de implantação das antigas escolas artesanais de Americana e Bata tais (SERVIÇO DO ENSINO VOCACIONAL, 1968a, p.14).

No que se refere ao "índice satisfatório de demanda escolar" que era uma das exigências da Secretaria da Educação para que fosse implantado um Ginásio Vocacional em cidades do Estado de São Paulo, não é de se estranhar porque a demanda por vagas era suntuosa e por isso, os índices de atendimento ao Ensino Secundário no Brasil no início da década de 60, coloca de uma maneira geral a possibilidade de qualquer localidade ter uma instituição Vocacional.

As unidades implantadas tanto em Americana quanto em Batatais ${ }^{38}$ começaram a funcionar inicialmente em prédios adaptados: fato semelhante aconteceu nas unidades de Rio Claro, Barretos e São Caetano do Sul.

O fato dessas unidades Vocacionais não terem um prédio próprio já estava previsto no artigo 25, que de acordo com Chozzini (2003):

[...] estabelece que os cursos poderiam ou não funcionar nas Escolas Industriais ou Escolas de Economia Doméstica e de Artes Aplicadas, inovações que eram o principal objeto da legislação. Essa hipótese das unidades do Vocacional funcionar junto a estas escolas nunca se concretizou. Só foi possível criar uma estrutura que deu origem aos Ginásios Vocacionais porque o parágrafo único do mesmo artigo estabelece que, com a autorização

\footnotetext{
${ }^{38}$ Cabe esclarecer que o Ginásio Vocacional de Batatais será abordado no próximo capítulo com a investigação dos possíveis critérios de seleção das cidades, buscando compreender os motivos dos ginásios vocacionais só terem existido no Estado de São Paulo.
} 
do Poder Executivo, os mesmos poderiam funcionar como unidade distinta [...], diretamente subordinada e orientada por órgão especializado em educação secundária (p.16).

Em 1963, seriam instaladas as unidades de Rio Claro e Barretos, denominadas Ginásio Vocacional Chanceler Raul Fernandes e Ginásio Vocacional Embaixador Macedo Soares. Além dessas unidades, previa-se ainda para esse mesmo ano a instalação de novos ginásios no Estado. As cidades escolhidas eram "Jundiaí, São Sebastião, São Carlos, Sorocaba, Taubaté, Campinas, Bauru, São José do Rio Preto, Presidente Prudente, Marília, São Caetano do Sul e São Bernardo” (MASCELLANI, 1999, p.85).

Quanto à implantação da unidade de Americana, encontra-se um dado importante que possivelmente revela um processo adverso e diferente do acontecido em São Paulo. Vejamos este relato apresentado na obra de Jacobucci (2002):

Um dos grandes responsáveis pela vinda do Ginásio Vocacional para Americana foi o prefeito da época, o senhor Cid de Azevedo Marques, um entusiasta admirador do sistema vocacional, e que, graças ao seu empenho político, aliado ao fato de ser amigo particular do governador do Estado, o Prof. Carvalho Pinto, conseguiu contemplar Americana com essa escola (p.18).

O relato, além de apontar um possível cumprimento da terceira exigência da Secretaria da Educação, mostra indícios de que o processo de escolha e os critérios de seleção das cidades foram promovidos pela rede de relações entre professor, prefeito e governador. Essa informação dá margem para verificar como aconteceu de fato todo esse processo e os possíveis motivos da instalação somente em São Caetano do Sul e não nas demais cidades conforme havia sido previsto.

No caso das cidades de Barretos e Rio Claro, os Vocacionais funcionaram em prédios provisórios até o ano de 1966 e 1967 respectivamente. Isso pode indicar que essas cidades estavam de acordo com a quarta exigência da Secretaria da Educação, pois mesmo sem prédio próprio para o funcionamento, o que parece ter motivado, foi a proposta pedagógica dos Ginásios Vocacionais.

Segundo depoimento do Orientador Pedagógico ${ }^{39}$ do Vocacional de Rio Claro retirado do trabalho de Marques (1985):

\footnotetext{
${ }^{39}$ Celestino Alves da Silva Júnior foi também diretor desse Vocacional.
} 
O Ginásio Vocacional iniciou seu funcionamento em 11 de março de 1963 , nas dependências do Grupo Escolar da Vila Operária. Ali ele ocupou algumas repartições e dividiu com os alunos do primário o pátio, banheiros e refeitórios. Ao final de $1963 \mathrm{~m}$ a permanência no Grupo Escolar [...] era inviável dada a necessidade de expansão de matrículas para o Ginásio Vocacional. Mudou-se então, para o casarão da fazenda na entrada do Horto Florestal da Companhia de Estradas de Ferro (p.84).

Porém, uma das maneiras escolhidas pela equipe do SEV para resolver essa questão do prédio, foi a convocação dos pais de alunos e interessados para a Assembléia Geral de Criação e Instalação da Sociedade e Amigos do Ginásio Vocacional. Nela, os pais:

[...] eram solicitados a colaborar para garantir condições efetivas para um ensino renovado, tais como: material didático adequado, financiamento de estudos do meio, [como] nem todos os pais podiam pagar as contribuições fixadas, muitos contribuíram com serviços, tais como: jardinagem, limpeza do prédio, eletrônica, teatro amador, dentro da própria profissão (MARQUES, 1985, p.89).

Coube à Sociedade Amigos do Vocacional '[...] pressionar os políticos do Partido Social Progressista local para conseguir junto ao Governador Adhemar de Barros o início da construção do prédio novo" (MARQUES, 1985, p.94).

O resultado dessa interferência culminou na mudança para o prédio novo em 20 de maio de 1968 e o Vocacional passou a chamar-se Ginásio Estadual Vocacional Chanceler Raul Fernandes.

No entanto, a última unidade Vocacional a ser instalada foi o Ginásio Vocacional Vila Santa Maria em São Caetano do Sul. Esse foi o único prédio construído pela prefeitura da cidade "em acordo com os governos estadual e federal" 40 em 1968.

Segundo pode-se verificar somente em 1968 foi construído um prédio para acolher esta proposta. Demorou quantos anos para que isto ocorresse? Fica evidente que ter um prédio próprio como indica o regimento interno não foi uma novidade. O que aponta uma questão no que se refere às condições da implantação de uma proposta inovadora como esta. O que isto pode revelar? Acreditavam no sucesso da proposta? Queriam de fato investir neste modelo de ensino?

O Vocacional de São Caetano do Sul, segundo o PPA, estava previsto para funcionar em apenas "[...] meio período escolar, isto é, vinte cinco horas semanais" (SERVIÇO DO ENSINO VOCACIONAL, 1968a, p.13-4). Porém, a implantação tardia fez

\footnotetext{
${ }^{40}$ Ver (SERVIÇO DO ENSINO VOCACIONAL, 1968a, p.15).
} 
com que essa unidade não pudesse aproveitar muito do espaço conquistado, pois em 12 de dezembro de1969 os militares invadem todas as unidades e colocam fim às experiências Vocacionais.

Mas, o fim da experiência Vocacional teve início muito antes de 1969, como já foi discutido no trabalho de Chiozzini (2003), e se acirrou em 19 de junho de 1969, quando do afastamento da coordenadora Maria Nilde Mascellani e da professora Áurea Sigrist.

De acordo com Mascellani (1999), as principais razões que levaram ao fim do referido projeto são: Controvérsias, sabotagens, repressão, mudança nove vezes de Secretário da Educação, afastamento de professores, e também, pelo período de funcionamento dos Ginásios Vocacionais coincidir com o momento do regime militar que, entre outras coisas, culminou no AI- $5^{41}$.

Em 5 de junho de 1970 é publicado o Decreto Estadual no 52460 que extingue o ensino renovado em todas as escolas estaduais. A partir desse decreto, as escolas pedagogicamente passam a ficar subordinadas à Divisão de Assistência Pedagógica. A experiência estava de fato extinta ${ }^{42}$. O ano de 1971 marca de fato, o fim da experiência dos Ginásios Vocacionais do Estado de São Paulo.

\subsection{Implantação do GVCP de Batatais ${ }^{43}$}

O processo de criação das unidades Vocacionais iniciou-se em meados dos anos de 1950 e 1960, sendo inauguradas em 1962 pelo decreto no. 39.766, de 13 de fevereiro de $1962^{44}$. Sendo Batatais, São Paulo, Americana, Rio Claro, Barretos e São Caetano do Sul, as cidades escolhidas para implantar o projeto do Ensino Vocacional no Estado de São Paulo, cabe investigar nessa pesquisa, sobre quais os principais elementos que influenciaram na implantação do vocacional na cidade de Batatais, uma vez que poderiam ter sido instalados em diferentes capitais do Brasil.

\footnotetext{
${ }^{41}$ Para ver mais detalhes sobre o processo de extinção da experiência, ver (MASCELLANI, 1999, p.97-100).

${ }^{42}$ Ver (MASCELLANI, 1999) e (TAMBERLINI, 1999 e 2001).

43 Atualmente, Batatais é Estância Turística e também conhecida como a "cidade dos mais belos jardins", está situada na zona sul do Planalto Brasileiro entre os Rios Pardo e Sapucaí, tendo como limites do município as cidades de: Altinópolis, Brodowski, São José da Boa Vista, Patrocínio Paulista, Sales de Oliveira, Jardinópolis e Restinga.

${ }^{44}$ Retirado do Diário Oficial de 14 de fevereiro de 1965.
} 
Porque a escolha dessas cidades e não de outras? Sobre os critérios de escolha das cidades Rovai (2005) esclarece que:

[...] havia um interesse dos idealizadores do projeto em diversificar a experiência educacional em comunidades diferentes. Os três vocacionais implementados foram os de São Paulo, com características de um centro mais cosmopolita; o de Batatais, uma região agrícola, e Americana, industrial (p.36).

O trecho não oferece informações suficientes para entender esse processo, embora informe talvez, a principal característica que diferenciaria essa unidade das demais. No entanto, sabe-se também que Batatais no momento de implantação do GVCP dispunha de um espaço, no caso o prédio da Escola Industrial, capaz de fornecer condições básicas para seu funcionamento.

No ano anterior a inauguração, já fora publicado no jornal "Folha de Batatais" duas notas sobre o GVCP. A primeira comunicava a comunidade da vinda a Batatais da coordenadora do Projeto do Ensino Vocacional, a Profa. Maria Nilde Mascellani e a segunda, divulgava a abertura das matrículas para a $1^{\text {a }}$. Série do Ginásio Vocacional, além de informar que :

[...] Os cursos Vocacionais [...] tem o caráter de curso básico destinado a proporcionar cultura geral, explorar as aptidões dos educandos e desenvolver suas capacidades, dando-lhes iniciação técnica e orientando-os, em face das oportunidades de trabalho para estudos posteriores (FOLHA DE BATATAIS, 26 nov. 1961).

Todo esse conjunto apresentado no trecho denota que a formação pretendida pela instituição não era apenas uma questão técnica, na medida em buscava dar uma formação integral ao seu aluno, bem como revelar ao mesmo, suas tendências e orientá-lo para a vida.

Esse modelo de educação Vocacional trouxe para Batatais uma inovação na educação e junto dela, um movimento novo para a cidade. O GVCP teve de articular-se ao/no movimento da cidade, estabelecendo vínculos e construindo ao mesmo tempo uma singularidade própria. Essa relação da escola com a cidade é profundamente trabalhada por Faria Filho (2002). Segundo afirma esse autor: "Escola e cidade, ambas criadoras e criaturas [...] a escola, neste sentido, se cria ao criar a cidade; é uma cidade que os momentos da escola, produz a escola como um de seus momentos" (p.107). 
Estaria assim esse modelo de escola pública se impondo dessa forma no e ao cenário da cidade? Com o desenrolar dessa história talvez possamos ver o que de fato pode ter acontecido segundo o olhar dos alunos.

\subsubsection{Batatais: a cidade e a educação}

A cidade tem seu nome e sua origem associados a acontecimentos políticos, econômicos e sociais, dentre eles a doação de uma sesmaria 45 "pelo governador da Capitania de São Paulo, Antonio da Silva Caldeira Pimentel, a Pedro da Rocha Pimentel” (Revista, 2005, p.9). Essa sesmaria, doada em 5 de agosto de 1728, denominava-se Batatais.

Tal denominação possui, pelo menos, quatro versões históricas para seu significado. A primeira delas, e a mais aceita, é fundamentada em relatos da época que descreve a atividade agrícola dos habitantes naturais da região. Segundo Fernandes (2004, p.7), “[...] plantações de batatas-doce, naturais ou cultivadas pelos índios caiapós [...]” foram encontradas pelos primeiros bandeirantes que chegaram à região. Outra versão defende que a palavra Batatais deriva de mbaiata, termo tupi que significa "rio cantante", '[...] uma alusão ao choque das águas nas pedras" (FERNANDES, 2004, p.7). Uma terceira versão, também baseada na língua tupi, defende que o nome tem sua origem no termo mboitata, "cobra de fogo", que na crença dos indígenas era o gênio que protegia os campos contra os incêndios ${ }^{46}$. Uma última versão, mais recente que as anteriores, diz que Batatais ou Batatal era uma expressão usada pelos mineiros antigos e que significava "lugar de ouro". Assim, Batatais era considerado “[...] o lugar de onde se extraía ouro, sobretudo de aluvião, pois as lâminas desse metal lembravam folhas de plantas de batatas" (FERNANDES, 2004, p7).

É interessante salientar, no entanto, que nenhuma das versões anteriores está de acordo com a primeira informação trazida por Squeff (2003). Segundo esta referência, Batatais vem do tupi mba'e-tatá:

Aparentemente, o topônimo se referiria as muitas plantações de batatas. Não há, porém, unanimidade quanto a essa interpretação. [...] Em suma, a origem do topônimo deste município é ainda uma questão em aberto. E isso, não obstante alguns documentos do século XVIII praticamente ratificarem o

\footnotetext{
${ }^{45}$ A cidade teve a sua origem a partir das divisões de 15 sesmarias que formaram algumas fazendas no começo do século XIX dando origem assim a cidade de Batatais.

46 Informação presente na página http://www.batatais.sp.gov.br/historia.asp, visitado em 25/06/2007.
} 
nome "Boitataes", o que confirmaria a origem indígena do vocábulo (SQUEFF, 2003, p.62).

De qualquer modo, a versão que parece ser a escolhida como oficial, e que se encontra representada no brasão e bandeira da cidade, vem do tupi mbaiata. A partir desse significado, foram criados esses símbolos que representariam a cidade:

O campo de prata do escudo representa a riqueza do solo de Batatais, aliada à pureza, elevação moral e de alma de seus habitantes. A faixa ondeada representa o nome indígina tupiguarani Mbaiata que, segundo alguns, significa "rio encachoeirado", ou "rio cantante", e que seria atribuído a Batatais pelo choque da água nas pedras de suas cachoeiras. A cruz do Cristo que se vê no centro do escudo era usada nas caravelas do descobrimento, e figurava também no brasão da monarquia portuguesa. Representa a religiosidade do povo de Batatais. O pergaminho verde é o símbolo da cultura e da arte, e a coroa acima do brasão é o símbolo de autonomia política do município. Quanto à bandeira, as cores que cercam o brasão lembram o nome do lugar onde se instalou o município: "Campos lindos das araras", aves de penas coloridas, principalmente azuis e vermelhas (FERNANDES, 2004, p.75).

Dando continuidade a essa história, é necessário recuar no tempo. Por volta de 1815, quando a cidade ainda era conhecida como "Arraial de Batatais",

[...] o capitão geral da Capitania de São Paulo, atendendo os desejos dos moradores do Arraial de Batatais, levados ao Bispo de São Paulo, pediu ao Príncipe Regente, futuro Dom João VI, que o Arraial dos Batatais fosse elevado à categoria de Freguesia de Bom Jesus da Cana Verde (FERNANDES, 2004, p.11).

Passados vinte e quatro anos com o título de Freguesia concedido pelo príncipe regente, no ano de 1839, a cidade deixa de ser Freguesia e eleva-se à Vila. Esse fato ocorreu em função da promulgação da Lei no. 128, decretada pela Assembléia Provincial, na pessoa do Dr. Venâncio José Lisboa que na época era Presidente da Província de São Paulo. Esse acontecimento também marcou a história da cidade que passou a comemorar seu aniversário no dia 14 de março.

Diante desse processo de desenvolvimento de sesmaria à Vila, Batatais recebe o título de cidade e comarca somente em oito de abril de 1875, pela Lei no. 20. Nessa época a cidade contava com uma "população de aproximadamente seis mil habitantes [...] mais de 220 edificações, três praças [...] e 13 ruas" (FERNANDES, 2004, p.14). 
A cidade de Batatais toma novos contornos com a produção cafeeira. Nesse sentido, o café torna-se uma atividade agro-exportadora para a elite de fazendeiros ${ }^{47}$ da cidade, que usa da mão de obra escrava e, posteriormente, da mão de obra de imigrantes, conforme destacado nesse trecho:

A importância do café, inicialmente cultivado por escravos e depois por imigrantes, principalmente italianos, foi tão grande que, ao final do século XIX, havia na cidade 2506 afro-brasileiros escravizados - a maioria trabalhando nas plantações -, enquanto toda a população do município não passava de 8500 pessoas (FERNANDES, 2004, p.16).

Sendo assim, o processo de urbanização de Batatais, e também de muitas cidades no interior do Estado de São Paulo, decorreu da economia cafeeira. O café permitiu uma forte presença de migrantes mineiros e, principalmente, uma grande movimentação de imigrantes japoneses e, em especial, italianos ${ }^{48}$. Segundo Pisani (1937):

A colônia italiana de Batatais, era bastante numerosa, tendo em seu seio pessoas das mais diversas profissões: arquitetos, lavradores, pintores, desenhistas, pedreiros, engenheiros, ferreiros, agricultores, pecuaristas, panificadores, industriais, comerciantes dos mais diversos ramos na cidade, banqueiros, advogados, mecânicos, carpinteiros, economistas, jardineiros, professores, farmacêuticos, músicos, cantores, e tantas outras profissões.

É desta mão de obra imigrante que se compuseram os primeiros trabalhadores da fazenda Macaúbas, em Batatais. Esta fazenda foi de propriedade do Dr. Domingos Corrêa de Moraes:

[...] um engenheiro civil, consultor, eletricista, fazendeiro em Batatais, duas vezes deputado constituinte federal tendo assumido quatro vezes (por curto espaço de tempo) o governo do Estado de São Paulo [...] Ainda jovem, ia de fazenda em fazenda para combater os formigueiros que atrapalhavam a produção agrícola (FERNANDES, 2004, p.36).

Sua figura é muito lembrada pelos Batataenses em razão das contribuições que trouxe para a cidade. Dentre elas destaco o '[...] acordo com a Companhia Melhoramento

\footnotetext{
47 De acordo com a revista da cidade, o café é introduzido na região de Batatais por Antonio Garcia de Figueiredo, proprietário da Fazenda Fortaleza. Para mais detalhes ver (FERNANDES, 2004, p.16-19).

48 Chegaram a Batatais no período de 1887 a 1907, cerca de trinta e seis famílias. Para mais detalhes ver, (FERNANDES, 2004, p. 29-34). Desses italianos, é muito significativo o número de famílias que enriquecem com a produção do café na cidade.
} 
de Batatais para a construção de uma usina hidrelétrica, que passou a fornecer energia para a cidade". Pensando numa forma mais adequada para escoar sua produção de café até o porto de Santos, Moraes:

[...] procurou a diretoria da Companhia Mogiana e realizou um grande negócio: ofereceu um terreno para a Mogiana construir uma ferrovia melhor e permitiu o uso das águas do córrego Macaúbas ${ }^{49}$, que seriam elevadas até a futura estação. Pagou ainda a construção das dependências da estação de trem e de duas casas para os funcionários que controlavam as linhas de trem. Em troca, escolheu o local da estação, distante apenas $800 \mathrm{~m}$ da sede da sua fazenda (FERNANDES, 2004, p.39).

Pode-se dizer que, seguindo o rastro do café, vieram às ferrovias e também famílias inteiras de imigrantes. Além disso, ao fato dessas ferrovias seguirem os interesses dos fazendeiros de café, nota-se que muitas vezes a ferrovia corria atrás da fazenda ou do núcleo urbano, ou ainda, foi ela a grande responsável pelo surgimento de cidades.

Em seguida, serão apresentadas algumas fotos que mostram a construção da usina hidrelétrica e a estação de trem na fazenda Macaúbas.

Conforme as fotos apresentadas nas Figuras 1 a 4, a implantação da Cia. Estrada de Ferro Mogiana ${ }^{50}$, em 1873, foi vista pela população batataense como um evento. "Era o lugar onde se via o trem passar, assistia-se a jogos de futebol e tomava-se um cafezinho com uma fatia de bolo de fubá, feito e vendido pela esposa do chefe da Estação" (FERNANDES, 2004, p.39).

A chegada da Mogiana, além de representar o desenvolvimento da malha ferroviária, tão importante para a exportação do café, trouxe também para a população batataense um novo espaço para o entretenimento e lazer.

A cidade se expande, ganha movimento e se destaca na região pela '[...] riqueza nos campos agrícolas e pastoris" (BARBIERI, 1997, p.8). Ela também oferece uma pecuária leiteira e uma significativa produção de grãos como: soja, café, feijão, milho, arroz, dentre outros. Além disto, ela também conta com um comércio voltado para a produção de aço inoxidável, metalurgia, materiais para a construção civil, artesanato e um diversificado número de indústrias, tais como: Fábrica de Laticínios e Derivados Liurgs, de Cerveja e

\footnotetext{
49 Nome dado a Fazenda que foi comprada em 1894, antes chamada Bertioga e que devido ao córrego (macaúbas) passar junto a nova parada do trem, Domingos de Moraes, em forma de homenagem resolve mudar o nome da fazenda, para Fazenda Macaúbas.

${ }^{50}$ A Mogiana ia de Campinas a Uberaba, em Minas Gerais, passando por Mogi-Mirim, Casa Branca, São Simão, Ribeirão Preto, Batatais e Franca.
} 
Gasosa, de Manufatura de Couro, de Utensílios Domésticos em Ferro, de Lataria, de Calçados, de Gelo, de Chapéus, de Manufatura de Latta, e etc.

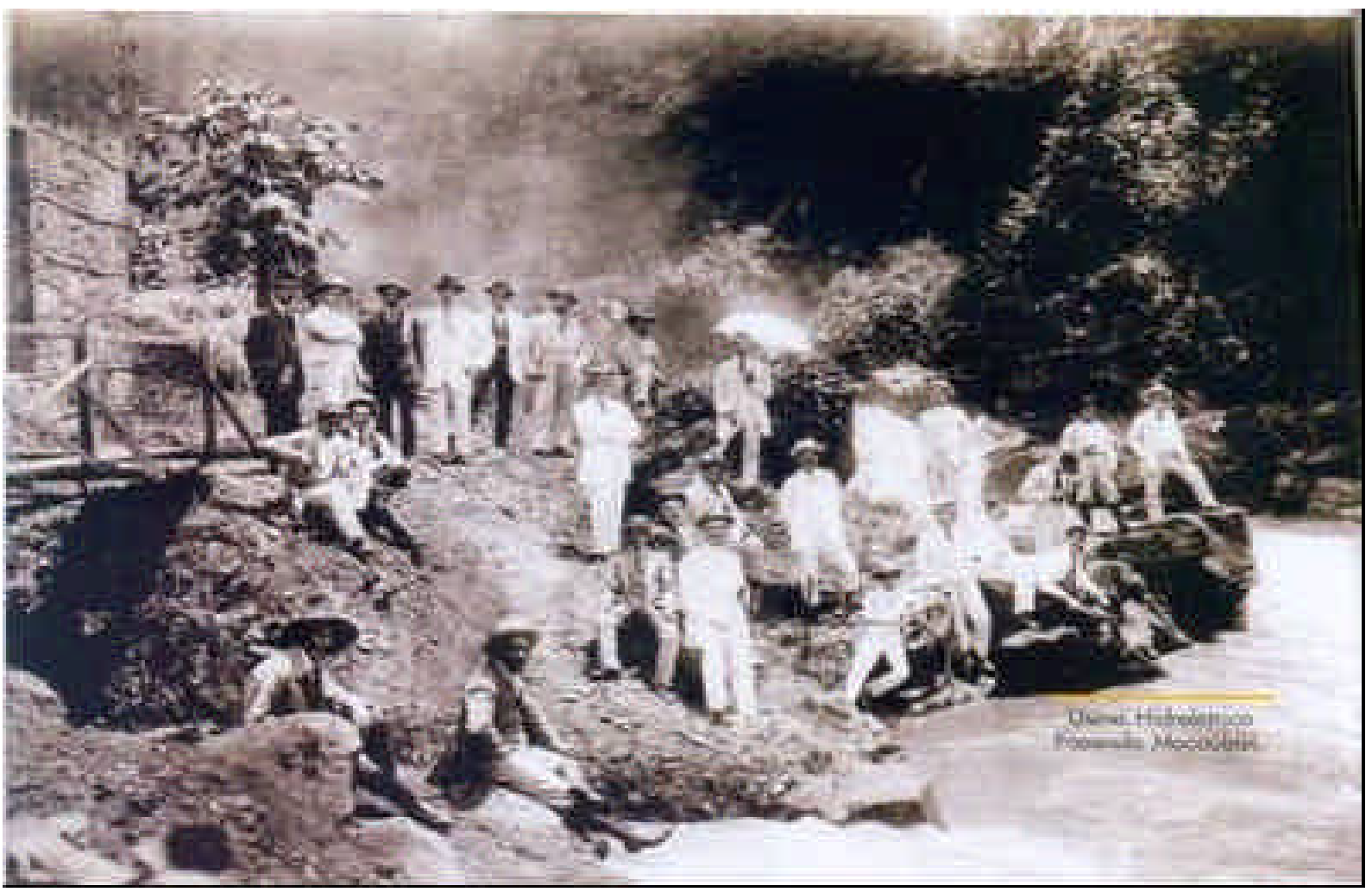

Figura 1. Construção da Usina Hidrelétrica na fazenda Macaúbas. Fonte: (FERNANDES, 2004, p.36)

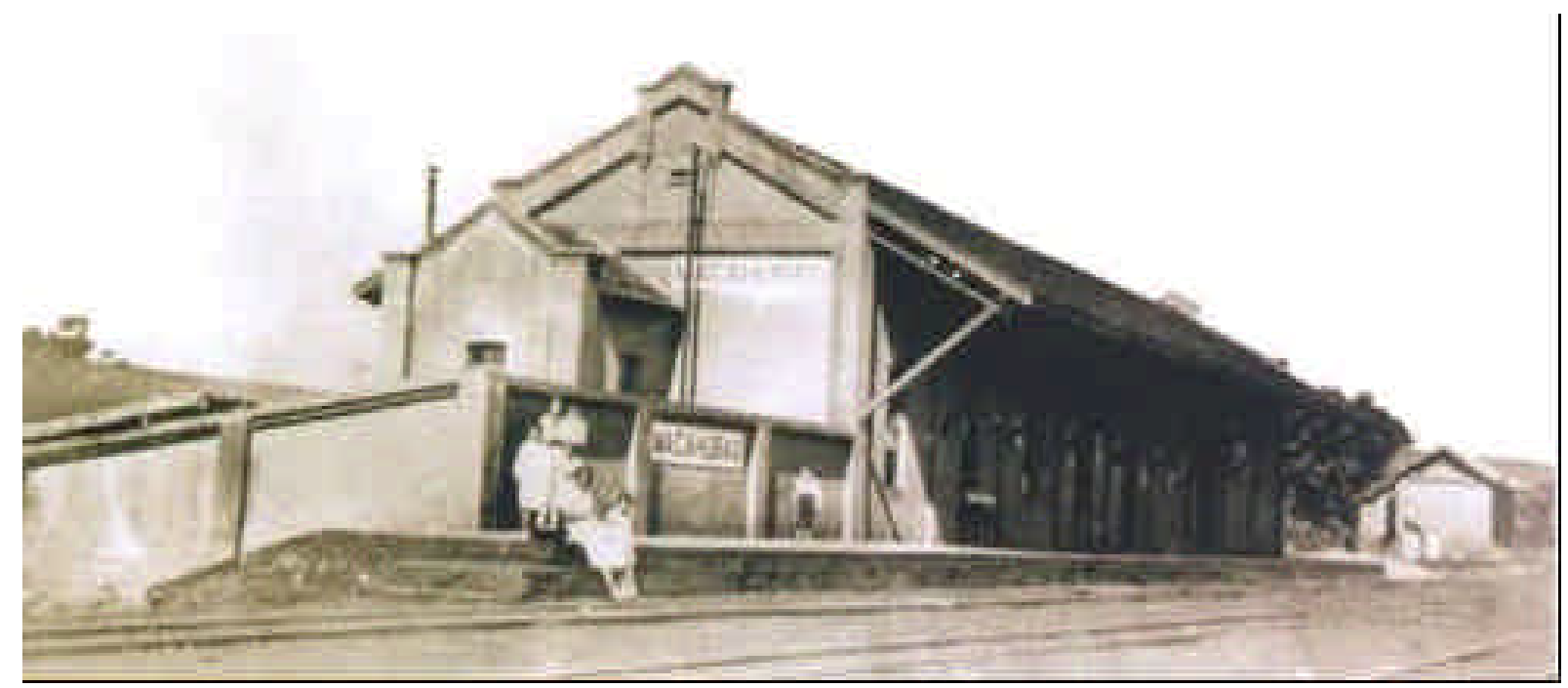

Figura 2. Estação Fazenda Mogiana. Fonte: (FERNANDES, 2004, p.39). 


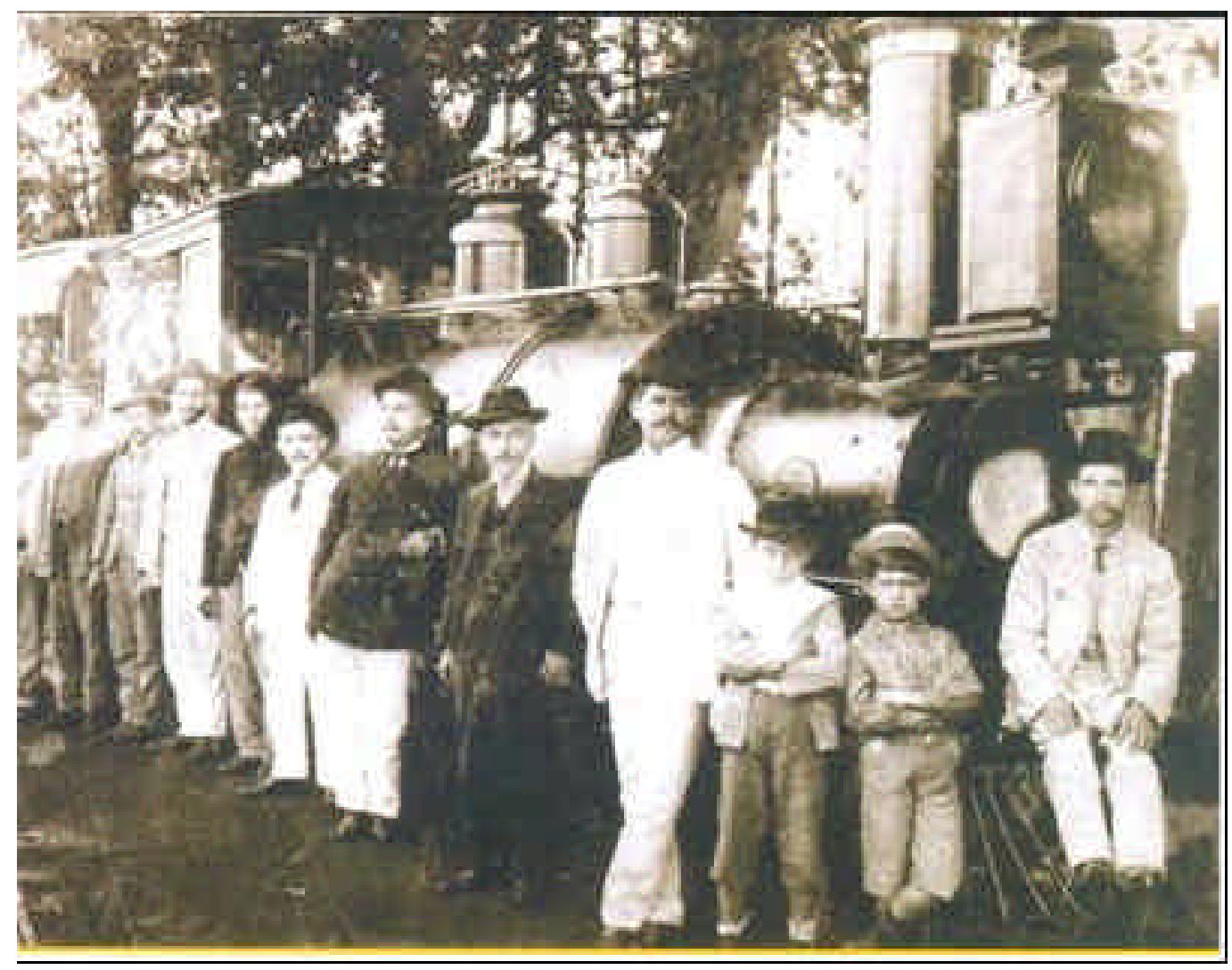

Figura 3. Locomotiva com usuários da Estação Mogiana. Fonte: (FERNANDES, 2004, p.19).

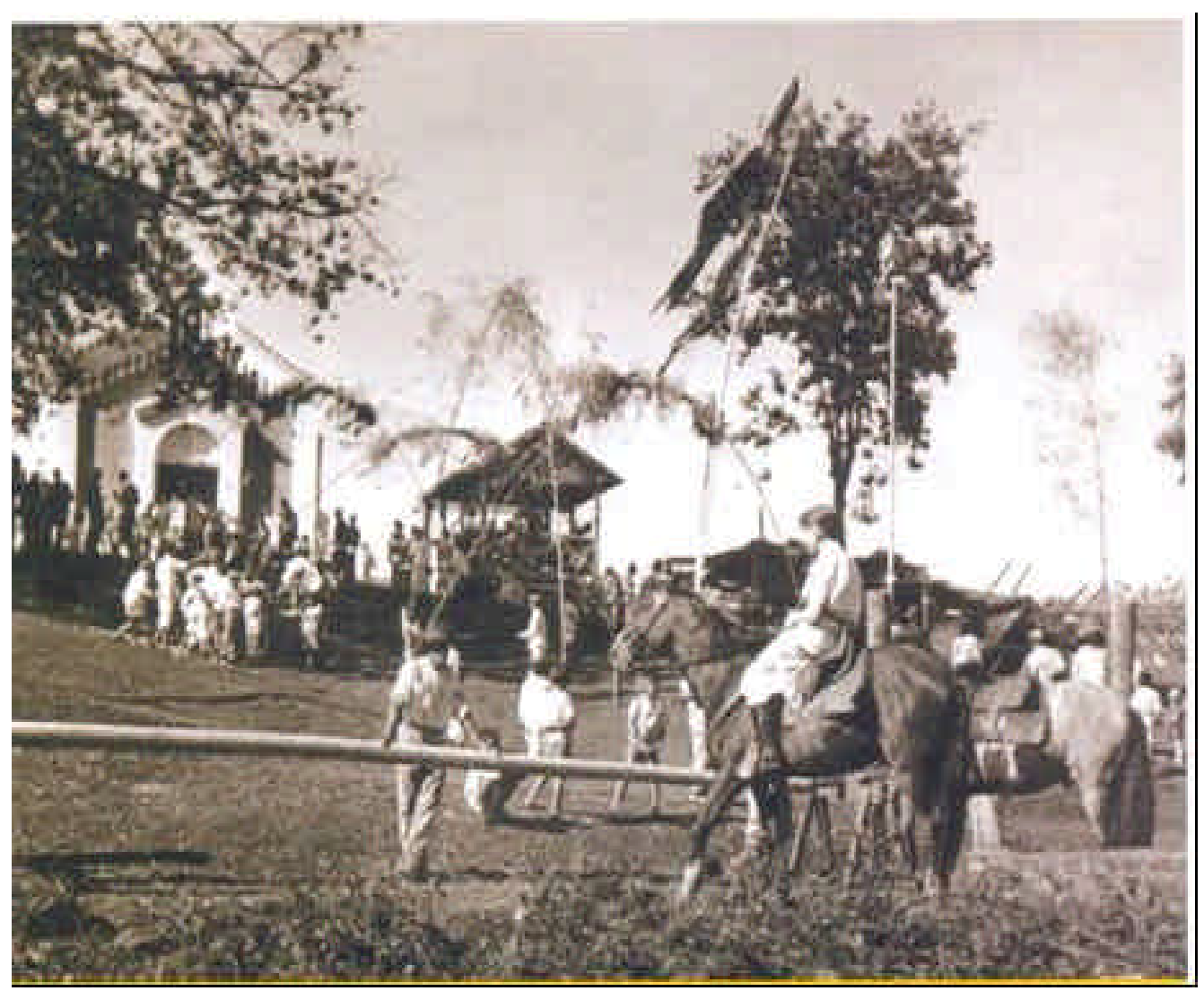

Figura 4. Festa junina na Fazenda Macaúbas. Fonte:(FERNANDES, 2004, p.37). 
Porém, esse desenvolvimento da cidade deve-se também à figura de Washington Luis, cidadão que marca um período da história de Batatais e do estado de São Paulo. Ele chega a Batatais na virada do século XIX para o XX, a convite de um amigo dos tempos da faculdade, que para atender aos muitos processos que envolviam os fazendeiros de café da cidade e região, resolve montar um escritório de advocacia. Esse seria o início de sua carreira profissional e também de seu engajamento na política.

Segundo Barbieri (1997), entre muitas funções, Washington Luis:

[...] exerceu atividade na Câmara Municipal de Batatais no período de 1895 a 1900. Em 1872 a Assembléia Provincial, promulgou o Código de Posturas do Município de Batatais. Em 1894, a Câmara recebe o projeto do código de Posturas do Município elaborado em 8 de julho de 1894 por Washington Luís (p.17).

Ainda sobre Washington Luis: "[...] tudo o que teve de estudar para isso foi fundamental para facilitar a sua compreensão das necessidades de melhoramentos do município" (FERNANDES, 2004, p.22), pois em 1896 foi eleito vereador na cidade, destacando-se como um defensor do município, dizendo ser de grande importância para a população os serviços do Poder Público. No entanto, no ano seguinte (1897), “[...] após ocupar a Presidência da Câmara, renuncia ao cargo devido a pressões políticas, mas logo é indicado para a Intendência Municipal, cargo semelhante ao do prefeito atualmente" (FERNANDES, 2004, p.22).

Segundo Fernandes (2004), enquanto Washington Luis esteve à frente do município, grandes foram suas contribuições: Colocou placas com os nomes das ruas e as casas ganharam números, também realizou algumas construções dentre elas, dos prédios de um mercado, da cadeia e de um matadouro. Reformou o teatro da cidade e comprou um prédio onde seria instalado o Paço Municipal, além de trocar e ampliar o sistema de iluminação. Participou: “[...] em 1899, com outros advogados de Batatais da criação da Assistência Judiciária para a proteção e defesa de presos pobres, sendo o primeiro presidente dessa entidade" (p.23).

No que se refere a história cultural de Batatais, duas figuras recebem destaque: "Cândido Portinari" e Conrado Sorgenicht Filho. O primeiro é filho de imigrantes italianos, cujos pais são: Batista Portinari e Domingas Portinari. Já Conrado fora neto de imigrantes alemães. 
Ambos marcam a história de Batatais pelo envolvimento com a arte. $\mathrm{O}$ pintor Cândido Portinari ${ }^{51}$, natural de Brodowski, foi batizado na antiga Igreja Matriz de Bom Jesus da Cana-Verde em Batatais. Das obras que existem na cidade é sabido que foi o resultado do convite de dois Batataenses ${ }^{52}$. Portinari pinta as 14 estações da Via Sacra e além dessas obras entregues no ano de 1954, também compõem a ornamentação da Igreja Matriz '[...] cinco cenas bíblicas e quatro imagens de Nossa Senhora Aparecida" (FERNANDES, 2004, p.44).

Enquanto Portinari cuida da ornamentação da Igreja de Batatais e é reconhecido em diversos países, Conrado é convidado a realizar seu trabalho nos vitrais “[...] do palacete do Monsenhor Joaquim Alves Ferreira, realizado entre 1949 e 1950, além dos vitrais da Igreja Matriz" (FERNANDES, 2004, p.48).

Outros trabalhos desse artista podem ser vistos na faculdade de Direito do Largo São Francisco, no Mercado Municipal e no Teatro Municipal na cidade de São Paulo. Em Fortaleza, '[...] na catedral local e em mais de 200 capelas de igrejas por todo o país" (FERNANDES, 2004, p.48).

Mais um fator que revela a importância da arte na cidade, é a criação da “Associação Beneficente Recreativa Operária" e da "Sociedade Pró-Arte”. A primeira é fundada em 20 de janeiro de 1920, a '[...] A.B.R. Operária funcionava inicialmente na Rua Cel. Joaquim Alves, no. 6. Em 1936, foi transferida para o Cine-Teatro São Carlos" (BARBIERI, 1997, p.74).

Quanto a Sociedade Pró-Arte, sua fundação está ligada à arte musical, conforme podemos notar nesse trecho do artigo de Cardoso ${ }^{53}$. Segundo a autora, essa sociedade fora:

[...] fundada por um grupo de amantes da música que organizaram uma orquestra e um coral para se apresentarem em Batatais e outras cidades como Brodowski, Bebedouro, Araraquara, Barretos e Pirassununga. As bases do movimento em prol das artes surgiram no Ginásio Vocacional Candido Portinari, tendo na área de Educação Musical o professor Osmar Rubens Jeyac, que, juntamente com o vice-diretor da escola, professor Marcelino José do Carmo, criou [essa] instituição com o propósito de incentivar o

\footnotetext{
${ }^{51}$ Sua obra é marcada por uma forte presença social, fruto de seu engajamento político, como membro do Partido Comunista Brasileiro. É uma expressão de temas e traços brasileiros. Portinari morre em 06 de fevereiro de 1962, intoxicado pelas tintas que usava. Mais detalhes sobre a vida e obra do pintor, encontra-se na página do Projeto Portinari: www.portinari.org.br.

52 Carlos Zambini, engenheiro-arquiteto da Igreja Matriz de Batatais e o fazendeiro José Martins de Barros, que pagou sete quadros da via Sacra, sendo os outros sete, doados pelo pintor. Ver (FERNANDES, 2004, p.44-7).

${ }^{53}$ Esse artigo "Sociedade Pró-Arte de Batatais" foi publicado na revista Amicus de Batatais, v.8 no ano de 2003 e também em (FERNANDES, 2004, p.56).
} 
exercício constante da música e outras ates, em 28 de março de 1966 (FERNANDES, 2004, p.56).

Porém, na "Folha de Batatais" encontra-se que:

[...] a inauguração da sede da Sociedade Pró-Arte 54 de Batatais, à Rua Dr. Leonardo Cavalcanti" ocorre somente no dia 02 de julho de 1967, ou seja, a socie dade só consegue sede própria um ano e seis meses após sua fundação. (FOLHA DE BATATAIS, 02 jul. 1967).

Mas, anterior à criação da Sociedade Pró-Arte, é fundada em 9 de julho de 1952 a "Sociedade Recreativa Flor da Mocidade". Segundo Fernandes (2004), esta associação “[...] se insere nas reivindicações da comunidade afro-brasileira do País e, especificamente de Batatais" (p.57). Posteriormente, seu nome é alterado para "Associação Recreativa Princesa Isabel", conforme se vê no excerto abaixo:

Em 17 de Janeiro de 1953 é lançada a pedra Fundamental da sede própria, nesta ocasião muda-se o nome da Sociedade para Sociedade Beneficente Recreativa Princesa Isabel. Em 1956 é formada uma comissão encarregada de orientar a construção da sede própria [...] Em dezembro de 1958, funda-se a Biblioteca José do Patrocínio da Sociedade [...] (BARBIERI, 1997, p.76).

Com o intuito de colocar esse projeto em ação, a sociedade Princesa Isabel realizou inúmeros eventos como bailes, quermesse e carnavais. Conforme aponta Barbieri (1997), “[...] de 1967 à 1977 a Sociedade abrilhantou também nosso Carnaval de Rua com seu Bloco e posteriormente a famosa Escola de Samba Princesa Isabel” (p.76).

No que se refere às "Artes Cênicas", em Batatais é inaugurado no ano de 1850 a casa de espetáculo São João que após a Proclamação da República, passa por algumas reformas, sendo reconhecida como Teatro Municipal São João.

Mais um teatro era construído na cidade em 1911, esse denominado "Santa Cecília" que estava localizado nos fundos da residência do cônego Joaquim Alves, tio do Monsenhor Joaquim Alves Ferreira. Sua figura é destacada na história de Batatais, por ter dedicado sua vida às atividades na Igreja Matriz desde 1907 e também pelo trabalho que realizou enquanto provedor da Santa Casa de Misericórdia. Além disso, nos anos de 1917 e 1918 foi responsável pela direção do Colégio São José, como veremos no item seguinte.

\footnotetext{
${ }^{54}$ Conforme poderemos ver, essa sociedade desde sua fundação teve um envolvimento grande com o GVCP, e esse envolvimento também registrado nos jornais de Batatais será detalhado no próximo capítulo.
} 
Em 1928, após dezessete anos de funcionamento o "Santa Cecília" teve de ser adaptado para a realização do culto católico, enquanto a igreja Matriz passava por reformas. Nesse mesmo ano, inaugura-se o Cine-Teatro Santa Helena, de propriedade da “Empresa Teatral Santa Helena Ltda”. Um ano após sua inauguração, essa empresa compra o teatro São Carlos e "mantém nele, diariamente, a mesma programação do Santa Helena, porém, com o ingresso mais caro" (FERNANDES, 2004, p.59). No entanto, a empresa Santa Helena torna-se "Empresa Teatral Para-Todos" nome esse que será dado ao cine teatro. Com o objetivo de homenagear o Monsenhor Joaquim Alves, essa empresa troca o nome do teatro "Para-Todos" para teatro "São Joaquim".

Quanto ao funcionamento desse teatro, Fernandes (2004) aponta: "Havia duas apresentações de filmes diariamente: a sessão das 19 horas, com preços reduzidos, era para o público feminino, enquanto o das 21 horas era para todo o público e sem descontos" (p.59).

Esse trecho faz pensar nessas questões: O que essa distinção de valor e público nas duas sessões estaria indicando na época? Seria este fato comum em outros teatros do país? Era esse procedimento uma das regras de funcionamento dos teatros?

Até esse momento Batatais ainda não possuía um teatro municipal com estrutura capaz de receber o público. Assim, inicia-se a construção do teatro municipal quando o "[...] governo do Estado de São Paulo concedeu à prefeitura verba para a construção do teatro" (FERNANDES, 2004, p.60). Essa obra foi finalizada 14 anos depois, em 1979 e o teatro ficou conhecido como Teatro Municipal "Fausto Bellini Degani", em homenagem a esse artista batataense.

Batatais, muito embora seja uma cidade de pequeno porte, possui uma grande efervescência cultura, ou seja, uma motivação cultura em várias áreas ao longo do século XX.

Após apresentar um pouco do cenário da cidade no que se refere as artes, busca-se em seguida trazer algumas informações sobre o ensino primário e secundário da cidade.

De acordo com os estudos de Cardoso (1999), “[...] os primeiros acontecimentos educacionais em Batatais ocorrem no Império”. A escola de primeiras letras fora criada “[...] pelo Conselho Provincial, em janeiro de 1828 [...]” (p.28).

Essa autora também aponta para o funcionamento de uma escola somente para o sexo masculino que funcionou na Fazenda Macaúbas, “[...] em prédio adaptado para as 
aulas e para a família do professor, em dependências cedidas pelo proprietário, sem qualquer remuneração" (CARDOSO, 1999, p.29).

Além desta, mais uma escola para meninos inaugurava-se em Batatais, era o “Grupo Escolar Rural Antônio Augusto Lopes de Oliveira Junior”. A nova escola,

[...] além de curso primário, pautado pelos grupos escolares, incumbia-se de ministrar sólidos e ótimos conhecimentos práticos e teóricos sobre a preparação de terras, plantio, trato e colheita de cereais, frutas, hortaliça, plantas têxteis e outros [...] (FOLHA DE BATATAIS, 1936 apud CARDOSO, 1999, p.52-3).

Cabe esclarecer que a criação dos Grupos Escolares surge "[...] no interior do projeto político republicano de reforma e de difusão da educação popular - uma entre as várias medidas da instrução pública mo estado de São Paulo implementado a partir de 1890" (SOUZA, 1997, p.20).

Ainda de acordo com Souza (1997),

[...] os grupos escolares constituíram em escolas modulares onde, era ministrado o ensino primário completo com um programa de ensino enriquecido e enciclopédico utilizando os mais modernos métodos e processos pedagógicos existentes na época [...] essa modalidade de escola primária implicou uma nova concepção arquitetônica. Pela primeira vez, surge a escola como lugar, a exigência do edifício escola como um aspecto imprescindível para o seu funcionamento, dotado de uma identidade (p.06).

Em razão dessa arquitetura, desse edifício escola é possível compreender o lugar escolhido para a implantação do Grupo Escolar Dr. Washington Luis em 1911. Após esse mais dois foram instalados no município: o Grupo Escolar Rural e o Grupo Escolar do Castelo, fundados em 1935 e 1947 respectivamente.

O primeiro, além de ser uma homenagem a Washington Luís ' $[$...] por seus serviços prestados a esta cidade [...]" (BARBIERI, 1997, p.40) foi "[...] um grande divisor de águas para a Educação pública de Batatais. Localizado ao centro da cidade, contava com alunos das famílias economicamente mais privilegiadas" (FERNANDES, 2004, p.61).

Quanto ao Grupo Escolar Rural de Batatais, este foi criado por decreto em 10 de novembro de 1935, mas foi instalo somente três meses depois, em fevereiro de 1936. De acordo com Barbieri (1997), esse grupo possuía cinco classes e um amplo espaço, onde funcionavam: 
[...] salas de aula, diretoria, portaria, museu-biblioteca, sala de trabalhos manuais femininos, gabinete, médico-higiênicos e dentários, salão de cabeleireiro para trabalhos manuais masculinos, Depósito de Material Agrícola e casa do servente-zelador (p.38).

Esse grupo chegou a funcionar em três períodos, ficando professores com seis horas de atividade diária. Isso pode significar que não havia vagas para atender a expansão de demanda do Ensino Primário nesta cidade.

Criado em 01 de janeiro de 1935, o Grupo Escolar do Castelo:

[...] possuía oito classes, em períodos desdobrados, com uma frequiência de 368 alunos [...] em 28 de janeiro de 1947, a escola altera a sua denominação para Grupo Escolar Monsenhor Joaquim Alves Ferreira. Entre 1957 e 1961, a estrutura física do grupo Escolar é modif icada, com o acréscimo de 6 salas de aula (BARBIERI, 1997, p.43).

No entanto, esses três grupos funcionam até a década de 70 e, para atender as modificações da Secretaria da Educação, em 1976, e dar continuidade ao ensino de $1^{\mathrm{a}}$. À $8^{\mathrm{a}}$. Séries, o Grupo trans forma-se em Escola Estadual de Primeiro Grau "Monsenhor Joaquim Alves Ferreira".

No que tange ao Ensino Secundário em Batatais, este fora marcado pela presença de grupos religiosos que dirigem e mantêm as escolas. Anteriores ao Ginásio Vocacional, existiam cinco escolas de Ensino Secundário na cidade: Colégio São José, Escola Normal Nossa Senhora Auxiliadora, Instituto de Educação Silvio de Almeida (IESA), Escola do Comércio e Colégio Soares.

O Colégio São José foi fundado por padres da congregação Salesiana em 1905, voltado para o público masculino e funcionava em sistema de internato. Esse colégio passou por algumas denominações, sendo a primeira: "Escola Agrícola São José" e que em 1905, era a única escola de práticas agrícolas na região, cujo objetivo era “[...] construir um Liceu de Artes e Ofícios com um Centro de formação de jovens, baseados nos Oratórios Salesianos" (BARBIERI, 1997, p.47).

Nessa época, a escola ficou sob a coordenação e direção do padre Atílio Cosci, da Congregação Salesiana, e em razão dos padres Claretianos comprarem da Diocese a propriedade do Colégio, muda-se o nome da escola para "Ginásio São José" 55.

No "O Jornal" (11 dez. 1960) de Batatais, encontra-se um anúncio do Colégio São José, que para além da exposição dos objetivos da escola, convoca os alunos aos

\footnotetext{
${ }^{55}$ Sobre a compra e direção da escola, ver (BARBIERI, 1997).
} 
exames de admissão e de segunda época. Dentre seus objetivos, pode-se destacar: “[...] integração da comunidade e aprimoramento espiritual [...]", esses poder-se-ia dizer que estariam ligados mais diretamente com a filosofia dos seus dirigentes.

Porém, anterior a esse colégio, existia o Nossa Senhora Auxiliadora fundado no ano de 1902. Este colégio era propriedade da "Congregação Filhas de Maria Auxiliadora" que também o dirigiam. Segundo Cardoso (1999), “o curso da Escola Normal Livre do Colégio Nossa Senhora Auxiliadora, contava igualmente na sua clientela com alunas de toda a região e inclusive de Minas Gerais" (p.56). Segundo "O Jornal”, as Irmãs Salesianas promoviam encontros entre pais e mestres com o intuito de gerar:

[...] um novo e confortante estímulo as alunas, pois através de uma identificação dos processos educacionais adotados pelos professores, e um sistema de atividade paterna bem orientada, é que se poderá, sem dúvida, alcançar mais facilmente os objetivos sadios e religiosos do próprio ensino (23 nov. 1969).

Conforme afirma Barbieri (1997), as Irmãs ficam na direção da escola até a década de 70, quando o colégio é fechado.

Outra instituição que marcaria o Secundário na cidade é inaugurada em1947, o Instituto de Educação Sílvio de Almeida, mais conhecida como IESA. Esta escola passou por vários endereços e denominações. Seu primeiro nome foi "Ginásio Estadual de Batatais" e, segundo Cardoso (1999), “[...] o novo Ginásio inicialmente funcionou no Grupo Escolar do Instituto Agrícola de Menores [...] fundado em 1946" (p.59). Ainda segundo a autora, foram atendidas no ano de 1948 nesta escola, da primeira a quarta séries, 90 alunos assim distribuídos: $1^{\text {a }}$. série feminina, 37 alunos; $1^{\text {a }}$. série masculina, 37 alunos; $2^{\text {a }}$. série mista, 44 alunos; $3^{\text {a }}$. série mista, 16 alunos; e $4^{\text {a }}$. série mista, 6 alunos. Em 1951, o IESA é transferido para a Praça Rio Branco, onde permaneceu por vinte e três anos. No ano de 1973, essa escola faz sua última mudança de prédio: “[...] trata-se de uma unidade integrada de $1^{\circ}$. e $2^{\circ}$. Graus e foi planejado para abrigar dois mil alunos" (CARDOSO, 1999, p.194).

O IESA foi a primeira escola pública de ensino médio na região. "O ensino, considerado de boa qualidade, levou à implantação, em março de 1954, do Curso Normal (para a formação de professores) no Sílvio de Almeida” (FERNANDES, 2004, p.62). Esse curso foi inaugurado em março de 1954 e a escola alterou seu nome para "Colégio Estadual e Escola Normal Sílvio de Almeida”. 
Quanto ao ensino profissionalizante, Batatais contou com a Escola Industrial e com a Associação Batataense de Ensino. A Escola Industrial “[...] foi criada pela Lei no. 77, de 23/2/1948 com a denominação de Curso Prático de Ensino Profissionalizante. Foi instalada em 14/12/1949 e passou a funcionar em $1^{\underline{0}}$ de março de 1950” (FERNANDES, 2004, p.64). Inicialmente, a escola funcionava nos períodos matutino e vespertino. Em 1951, foi criado o curso noturno. Desde então, esta escola teve várias denominações: Escola Industrial de Batatais, Ginásio Industrial Estadual de Batatais, Ginásio Industrial Estadual Antônio de Pádua Cardoso (1971), Centro Interescolar e EtecSG.

A Associação Batataense de Ensino foi criada em 1937 e ficou conhecida por Escola do Comércio. Ela ofereceu o $2^{\underline{0}}$ ciclo com habilitação profissional plena em Contabilidade. Segundo Barbieri (1997), essa escola possuía três séries: admissão, propedêutico e perito contador. As aulas eram também ministradas no período noturno.

De acordo com Cardoso (1999):

[...] a criação desta escola representou um grande benefício para a cidade, pois preencheu uma lacuna nos cursos de $2^{\circ}$. ciclo, à medida que preparava sua clientela para o desempenho de atividades mercantis, sendo, portanto um curso profissionalizante (p.55).

No âmbito particular, a primeira escola de Ensino Secundário que surge na cidade data de 1910. Essa escola era de propriedade do professor e jornalista José Joaquim da Costa Soares Júnior e, no ano de 1918, converteutse no Colégio Soares (A.C.M.B., 10/09/1918, p.189v, apud CARDOSO, 1999, p.38). Devido ao não cumprimento dos rigores das leis educacionais então em vigor, essa escola foi fechada.

Essa apresentação do mapa das unidades educacionais existentes na cidade de Batatais foi importante para compreender-se o contexto educacional que se desenvolvia no momento anterior à implantação do Ginásio Vocacional. Antes de tratar especificamente do GVCP, foi necessário fazer esse percurso pela história da cidade com o intuito de visualizar os diferentes aspectos que a caracterizaram e que, possivelmente, vieram a contribuir na escolha dessa cidade para a instalação de uma unidade Vocacional.

É importante considerar que a história da cidade de Batatais relatada anteriormente mostra sua configuração social, econômica e cultural. Todos esses aspectos reunidos deram condições para a implementação do GVCP. Além disso, cabe fazer um destaque quanto aos critérios já apontados no item 2.2.1 e 2.3. A cidade de Batatais contemplou com certeza pelo menos uma das exigências: ela tinha um prédio pronto (onde 
funcionaria a Escola Industrial), um espaço possível de fazer adaptações e que pareceu fundamental para a instalação do Ginásio Vocacional. Ademais, o Ensino Secundário oferecido na cidade era em sua maioria privado, ou seja, para poucos. Deste modo, pode-se entender que o Vocacional foi mais uma opção de instituição pública voltada para o Ensino Secundário que possivelmente atenderia uma parcela dos jovens da cidade e da região. Muito além disto, foi um projeto experimental que apresentou uma proposta diferenciada de educação.

É possível inferir também que a instalação do Vocacional na cidade deveutse ao fato desta apresentar uma preponderância no desenvolvimento de trabalhos em torno da agricultura e das artes, áreas estas centrais do currículo do GVCP. 



\section{Capítulo}

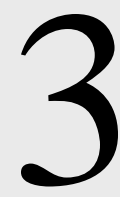

\section{Ginásio Vocacional “Candido Portinari”}

U ma vez apresentado o cenário educacional de Batatais, este capítulo adentra o modelo educacional do Ginásio Vocacional "Cândido Portinari”56. Pretende-se, assim, fazer uma caracterização da escola: criação, localização, funcionamento, objetivos, público e as práticas desenvolvidas e relatadas por ex-alunos que vivenciaram a experiência do GVCP. Esse processo será realizado mediante o conteúdo apresentado nas seguintes fontes: Planos Pedagógicos e Administrativos dos Ginásios Vocacionais do Estado de São Paulo (PPA); notas de jornais da cidade de Batatais; entrevistas transcritas dos ex-alunos do GVCP; e fotografias desta experiência.

\subsection{Planos Pedagógicos e Administrativos dos Ginásios Vocacionais do Estado de São Paulo}

Este documento foi produzido pela equipe pedagógica do Ensino Vocacional, composta pela coordenadora do SEV Maria Nilde Mascellani e as educadoras Maria da Glória Pimentel, Tiana Guimarães e Yara Boulos. Segundo Mascellani (1999), o documento “[...] não traz os nomes dos autores por motivo de segurança, em meio ao clima de repressão política do período" (p.62). Seu objetivo é explicitar e nortear os princípios e diretrizes gerais de funcionamento dos Ginásios Vocacionais. Além de oferecer parâmetros para todas as unidades Vocacionais, indicava a necessidade de se construir e demarcar a especificidade de cada uma das unidades. Sua elaboração em 1968, seis anos após a implantação da experiência,

\footnotetext{
${ }^{56}$ O Ginásio Vocacional recebeu esse nome em homenagem ao grande artista que buscou retratar os traços brasileiros em suas pinturas. Cândido Portinari ficou conhecido internacionalmente e teve o fim de sua vida marcado por uma intoxicação pelas tintas que usava, vindo a falecer no dia 06 de fevereiro de 1962, poucas semanas antes da inauguração do ginásio. Além dis so, a que se questionar por que o Vocacional recebeu esse nome. Seria porque Batatais, além de possuir uma quantidade significativa de telas do pintor, também se localiza próxima a Brodoswi, cidade natal Portinari? Seria para homenagear o pintor, que havia falecido uma ou duas semanas após a inauguração do GVCP? Ou a equipe Vocacional escolheu homenagear o pintor por tua atuação política, por seu engajamento no Partido Comunista Brasileiro?
} 
pode ser explicada pelo fato dos Ginásios Vocacionais constituírem um projeto experimental, não sendo assim possível a elaboração do documento sem antes colocar em prática tal proposta.

O documento está estruturado em nove partes, assim organizado:

1. Metodologia da Apresentação [do PPA];

2. Significado da Experiência;

3. Breve Histórico da Experiência;

4. Prática Pedagógica - Suas Constantes;

5. Pesquisa de Pontos Críticos da Prática Pedagógica;

6. Prática Pedagógica e Administrativa;

7. Planos Administrativos Comuns às Unidades de Ensino Vocacional;

8. Planos Administrativos Específicos de Cada Unidade de Ensino Vocacional;

9. Planos: $2^{\circ}$. Ciclo Vocacional, Ginásio Vocacional Noturno e Ginásio Estadual Vocacional de São Caetano do Sul.

Inicialmente, é importante salientar que não foi dado ênfase a todos os tópicos listados anteriormente, uma vez que este não é o foco deste trabalho. Optou-se por tratar somente aqueles que serviram como referencias para construir o objeto desta pesquisa ou que foram pontuados nas entrevistas com os ex-alunos do GVCP de Batatais, ficando os demais tópicos à espera de investigação em outras pesquisas. Deste modo, serão apresentados a seguir os principais tópicos que embasarão a análise deste trabalho.

O primeiro tópico a ser destacado refere-se a $3^{\mathrm{a}}$. parte, "Breve Histórico da Experiência". Deste, serão abordados os temas: "Instalação das Unidades", "Pesquisas de Comunidades" e "Integração Escola e Pais".

O PPA informa que a instalação das unidades partia do "[...] interesse de diversificar a experiência educacional de diferentes comunidades [...]” (SERVIÇO DO ENSINO VOCACIONAL, 1968a, p.14). Isto é um indicativo para o esclarecimento dos motivos que levaram à implantação da experiência nas cidades de Batatais, São Paulo, Barretos, Americana, Rio Claro e São Caetano do Sul, conforme descrito no item 2.3 desta dissertação.

Com relação às "Pesquisas de Comunidades", o PPA elucida: 
Determinado os locais onde se instalariam os Ginásios, iniciou-se os estudos das comunidades. Essas pesquisas foram feitas inicialmente com a colaboração de voluntários do Instituto de Relações Sociais na Indústria, com professores que freqüentavam o primeiro curso de treinamento promovido pelo SEV, por alunos de Ciências Sociais das Faculdades de Filosofia da USP e Sedes Sapientiae. [...] Procedeu-se em todas as comunidades a uma sondagem de características culturais e sócioeconômicas. Pelo processo de amostragem, foram escolhidas, para darem as informações desejadas, as famílias de crianças que freqüentavam os quartos e quintos anos escolares bem como elas mesmas em relação a alguns aspectos da sondagem (SERVIÇO DO ENSINO VOCACIONAL, 1968a, p.15-6).

Segundo o documento, “[...] os dados da pesquisa são debatidos com professores e orientadores de cada Ginásio Vocacional e com alguns grupos de pais para efeito de programações comuns [...]" SERVIÇO DO ENSINO VOCACIONAL, 1968a, p.17).

A "Integração Escola e Pais" é também um aspecto importante na proposta Vocacional, porque:

[...] os elementos de ligação com que a escola conta para penetração na comunidade são os próprios alunos e seus familiares. Por este motivo, insiste-se muito no trabalho com os pais, além da valorização de sua participação no processo educativo de seus filhos (SERVIÇO DO ENSINO VOCACIONAL, 1968a, p.23).

Assim, o propósito do trabalho com os pais estava em fazer com que eles pudessem se organizar dentro da escola em diversas atividades e, depois de algum tempo, suas vivências ofereceriam condições para se organizarem em sociedade.

O trabalho de Marques (1985) abordou a participação dos pais e suas colaborações no Vocacional de Rio Claro. Segundo a autora, '[...] os pais que não podiam pagar as contribuições afixadas [no Vocacional] acabavam contribuindo com serviços [de] jardinagem, limpeza do prédio, eletrônica [...]” (p.89).

Com o funcionamento cotidiano de cada Vocacional e o aparecimento de problemas de diversas ordens, foi necessária uma maior participação dos pais. Este fato culmina, segundo o PPA, na criação das "Sociedades de Pais e Amigos do Ensino Vocacional" 57 , no ano de 1962. Essas sociedades tinham como objetivo "[...] levá-los [os

\footnotetext{
57 Ver (SERVIÇO DO ENSINO VOCACIONAL, 1968a, p.194), item 7.7: "Do Trabalho com a Sociedade de Pais e Amigos do Ginásio Vocacional”.
} 
pais] a uma participação consciente no processo educativo dos filhos e na elevação do nível educacional da comunidade" (SERVIÇO DO ENSINO VOCACIONAL, 1968a, p.23).

Além de acompanhar a aprendizagem dos filhos, os pais também participavam de atividades na escola. De acordo com Paulo Ricardo $\operatorname{Simon}^{58}$ a presença e a:

[...] participação [dos pais] eram constantes, o que tornava a escola uma real extensão de nossas casas. Eles cantavam no coral PROPAF - Professores, Pais e Funcionários [...], participavam dos cursos de Matemática Moderna (ministrados pela professora Renate Watanabe, mãe de aluno) e da Associação de Pais, na organização de eventos e na discussão de temas relevantes à nossa educação, compareciam às nossas exposições de trabalhos semestrais de síntese, e contribuíam, com seus talentos e possibilidades, para o constante aprimoramento da Escola (ROVAI, 2005, p.170).

Outro trecho que confirma a presença dos pais na escola aparece no trabalho de Tamberlini (1999):

[...] a relação com a família e comunidade se realizava com vistas à transformação social, à melhoria do nível da comunidade [...] havia um esforço para que todos contribuíssem para o bom funcionamento da escola, cada qual dentro de suas possibilidades: uns ajudavam com dinheiro, outros cooperavam com trabalhos prestados, outros ministravam palestras e assim por diante (p.119).

Tanto a participação dos pais e da comunidade no Vocacional, quanto o próprio funcionamento desta escola dão indícios de que a experiência foi uma tentativa de democratização do Ensino Secundário no Estado de São Paulo.

A quarta parte do PPA é a mais extensa, porque aborda a "Prática Pedagógica - Suas Constantes”. Dentro deste item, vários temas mereceram destaque nesta pesquisa e serão apresentados a seguir.

A "Pesquisa de comunidade para fins de planejamento e avaliação de currículo" foi justificada com a seguinte menção:

[...] uma experiência pedagógica deve nortear-se por dados de realidade que implicam num conhecimento do quadro social no qual vai desencadear-se a experiência [...]. Porém, essa apreensão da realidade não se coloca num nível meramente descritivo, por ela deve ser compreendida na sua dinâmica, implicando os seres humanos que movimentam nesta realidade e as relações de mantêm entre si e com todo o quadro social (p.31).

\footnotetext{
58 Ex-aluno do vocacional de São Paulo, que teve seu texto publicado no livro organizado por Rovai em 2005.
} 
É dentro deste tema que se encontra a descrição do processo de caracterização da provável clientela do Ginásio Vocacional. Segundo o PPA, esta caracterização limitourse a uma sondagem da:

[...] população de pais de alunos de $4^{\mathrm{a}}$. ano primário, de todos os estabelecimentos de ensino da cidade, já que êsses alunos serão a provável clientela de um curso $1^{\circ}$. ciclo de Ginásio Vocacional a ser instalado. A análise do nível sócio-econômico desta população foi feita através da aplicação da escala de prestígio das profissões, elaborada pelo professor Hutchinson, escala esta produto de uma série de estudos feitos em diferentes regiões do Brasil. Essa escala separa os tipos de ocupação segundo seu prestígio, em sete diferentes níveis sócio-econômicos, que se reduzem a duas grandes categorias, a saber: a. ocupações não manuais, que gozam de maior prestígio em nossa sociedade. b. ocupações manuais que, em têrmos de prestígio, encontram-se em uma posição inferior (SERVIÇO DO ENSINO VOCACIONAL, 1968a, p.35).

O "Estudo da Clientela Escolar através de Entrevistas" do PPA refere-se “[...] a formulações e procedimentos [...] desenvolvido nos Ginásios Vocacionais, no Estado de São Paulo, pelo Serviço do Ensino Vocacional" (p.50). Dentre estes procedimentos, os instrumentos que permitem fazer um estudo da clientela são:

[...] as provas de escolaridade, os testes psicológicos e as entrevistas. A função de seletividade, visando aprovação ou reprovação de candidatos tradicionalmente ligada a este ou aquele destes instrumentos nos chamados exames de admissão - é transfiguradas, primeiramente, pela interpretação destes instrumentos; em segundo lugar, pela sua caracterização como ponto de partida para a compreensão global do aluno por parte da equipe educacional; e, finalmente, como ponto de partida para a compreensão global da nova situação por parte do aluno [...] (p.51-2).

Na descrição das "Técnicas Pedagógicas" é que se encontra a proposta do "Estudo do Meio" e do "Trabalho em Grupo". Acreditava-se que estas técnicas ajudariam os alunos na construção de um pensamento operatório, uma vez que todas envolviam situações de estudo e investigação.

O "Estudo do Meio" constituía-se em:

[...] uma das técnicas pedagógicas de mais largo emprego nos Ginásios Vocacionais. Da $1^{\mathrm{a}}$. à $4^{\mathrm{a}}$. Série, estudando o próprio Ginásio, a comunidade, o Estado, o Brasil e o Mundo, encontra o aluno um grande número de oportunidades de sair da própria sala de atividades entrando em contato direto com a realidade através de uma experiência vivida e não livresca (SERVIÇO DO ENSINO VOCACIONAL, 1968a, p.96-7). 
Esta técnica necessitaria ser planejada por toda a equipe de professores do Vocacional, uma vez que a atividade deveria contemplar as diferentes áreas do currículo. Além disso, uma série de conceitos poderia ser trabalhada durante esta atividade: “[...] educação, escola, cultura, democracia, governo, lei, hierarquia, etc" (SERVIÇO DO ENSINO VOCACIONAL, 1968a, p.98).

Sobre o "Trabalho em Grupo", consta no PPA que essa atividade aparece caracterizando todas as situações da vida escolar.

Seja no contato com os professores e com os pais, a técnica fundamental usada pela escola é sempre o trabalho em grupo. Deste modo, consegue-se planejar condições para que os três segmentos da estrutura escolar - o grupo de alunos, de professores e de pais - se percebam como participantes do mesmo processo - a situação crítica e transformadora. Na faixa de trabalho com os alunos, o trabalho em grupo aparece caracterizando as situações de aprendizagem. Aparece, deste modo, integrado a todas as técnicas de trabalho, sendo utilizado por todas as áreas (SERVIÇO DO ENSINO VOCACIONAL, 1968a, p.115).

Rovai (1996), por tratar do processo de ensino-aprendizagem, traz a lume também a questão do trabalho em grupo, afirmando que essa atividade deveria também auxiliar os alunos no processo de avaliação e deveriam constituir-se em:

[...] instrumento de autoconhecimento a fim de que o ser humano aprenda a se ver como um ser em processo dentro de uma dada situação e que sua interação com esta situação vá aprendendo a se conhecer e a se reconhecer em seus interesses, afinidades e gostos, em seus valores, crenças e atitudes, e também em suas possibilidades e limitações, aprendendo a lidar com estas questões de maneira construtiva, no sentido dialético que conjugue superação e aceitação individual e grupal (p.610-1).

De acordo com essas formas de estudo e avaliação desenvolvidas nos Vocacionais, pode-se supor que professor e aluno necessariamente se envolveriam numa nova dinâmica dentro da escola que, conseqüentemente, acabaria por refletir ou se incorporar em suas práticas cotidianas fora da escola.

Ainda na quarta parte do PPA, encontram-se descritas as "Instituições Didático-Pedagógicas" oferecidas de $1^{\mathrm{a}}$. a $4^{\mathrm{a}}$. séries do Ensino Vocacional. Dentre elas destacam-se: Cantina Escolar, Cooperativa, Banco Escolar, Escritório Contábil e Acampamento. Essas instituições visavam "[...] propiciar vivências dos conceitos elaborados nas diferentes áreas, assim como dar oportunidade de participação e ação grupal" (SERVIÇO 
DO ENSINO VOCACIONAL, 1968a, p.150). Em cada série o aluno tinha a oportunidade de vivenciar uma dessas atividades. A Cantina, por exemplo, era organizada e dirigida por alunos da $1^{\text {a }}$. série. E para que ela pudesse funcionar foi:

[...] eleita uma diretoria, geralmente composta de Presidência, Secretário e Tesoureiro entre todas as $1^{a}$ séries, através de votação. Todos os dados que resultam das atividades dessas vivências na cantina e os problemas que surgem no decorrer dos trabalhos práticos são levados para serem sistematizados e discutidos em classe (SERVIÇO DO ENSINO VOCACIONAL, 1968a, p.152).

Essa atividade também era planejada para que os alunos pudessem desenvolver na prática a:

[...] a) análise contínua dos desequilíbrios econômicos, resultantes das tendências econômicas; b) percepção dos meios econômicos e sociais, para análise contínua dos princípios de cooperação econômica (SERVIÇO DO ENSINO VOCACIONAL, 1968a, p.153).

Todo o trabalho da Cantina era organizado por equipes, sendo cada uma composta de cinco alunos divididos nas seguintes funções: caixa (um aluno); balconistas (dois alunos); empacotador (um aluno); e gerente comercial (um aluno).

$\mathrm{Na} 2^{\mathrm{a}}$. série, a Cooperativa era a instituição onde os alunos tinham liberdade para experimentar e procurar soluções dos eventuais problemas dessa instituição. Para isso fazia-se uma eleição.

A delegação de poderes à diretoria da cooperativa se faz através de eleições [...] Primeiramente, forma-se uma Secretaria Eleitoral, com regulamento feito pelos próprios alunos, que passa a receber as inscrições das chapas das quais se exige um Plano de Ação que deve ser executado durante a gestão. Os alunos votam em cédula única, colocando-a em urnas, às vezes improvisadas em caixas de sapatos, dispostas por seções e instaladas nas salas de aulas. Após a votação, cada seção apresenta uma ata das ocorrências e apuram-se os resultados que, após computados, proclama os eleitos [...] os eleitos, são empossados em uma Assembléia Geral, no qual tomam parte todos os alunos-cooperados da escola e na qual a diretoria anterior apresenta o relatório, contendo as realizações e a prestação de contas (SERVIÇO DO ENSINO VOCACIONAL, 1968a, p.156).

Nota-se que nessa atividade, assim como em outras, a eleição para a divisão de tarefas era prática recorrente e isso também seria uma forma de preparar o jovem para a 
vida em comunidade, a fim de que ele compreendesse o funcionamento e a organização da sociedade da época.

No trabalho de Rovai (1996), entre muitos relatos, encontramos o de um exprofessor de Práticas Comerciais ${ }^{59}$ que fala da finalidade da cooperativa. Segundo ele:

O objetivo principal era desenvolver o cooperativismo dentro de seus 10 conceitos básicos [...], era uma forma de incentivar o trabalho em grupo. Reforçava aquele conceito de trabalho em grupo, onde cada um deveria dar sua participação [...] era também uma forma de perceber que, em sociedade, poderiam fazer muita coisa de útil, já dando um posicionamento para uma possível escolha do que poderiam fazer, depois que saíssem do Vocacional (p.224-6).

Na perspectiva de aprofundar os conceitos trabalhados anteriormente é que, na $3^{\mathrm{a}}$. e $4^{\mathrm{a}}$. séries, os alunos viriam a desenvolver trabalhos no Banco Escolar e no Escritório Contábil, respectivamente.

O Banco, segundo encontra-se definido no PPA, deveria ser:

[...] organizado em seções, cada uma com suas finalidades, mas coordenadas entre si. Nele existiam os seguintes cargos: 2 caixas, 1 correntista, 2 municiadores e 1 relações públicas. E] além de organizarem fichários e terem o domínio e mecanismos das operações financeiras, os alunos também faziam estágio e estudo do meio em bancos da comunidade onde, [...] através da observação das entrevistas e das pesquisas, estudam outras seções e departamentos de um banco (SERVIÇO DO ENSINO VOCACIONAL, 1968a, p.158).

No caso do Ginásio Vocacional da capital, um professor revela alguns aspectos dessas atividades:

[...] nós conseguimos através de um banco particular a edição e emissão de talão com 20 cheques, e só era válido dentro da escola: $\mathrm{O}$ aluno comprava na Cantina, na Cooperativa, tudo com cheques. A associação de Pais construiu uma sala e conseguimos organizar o Banco [...] para poder trabalhar com os cheques, os alunos faziam o depósito da mesada que os pais davam, e com isto já iam fazendo essa prática de como se preenche um cheque [...] E também os nossos alunos de primeira [e segunda] séries, que trabalhavam na Cantina e Cooperativa, depositavam o dinheiro no Banco, a grande coqueluche, sem dúvida nenhuma, foi o Banco (ROVAI, 1996, p.225).

\footnotetext{
${ }^{59}$ Gilberto A. Casolli era o nome do professor que trabalhou no Ginásio Vocacional "Oswaldo Aranha", na cidade de São Paulo. Ver (ROVAI, 1996).
} 
No Vocacional de Americana, segundo Balzan (2005), o Banco “[...] funcionava impreterivelmente das 12 horas às $13 \mathrm{~h} 30$, sob a supervisão do professor de Práticas Comerciais" (p.136) ${ }^{60}$. Cabia aos alunos da $4^{\mathrm{a}}$. série cuidar do funcionamento do Escritório e, conforme o PPA descreve, os alunos:

[...] escrituram fichas de contabilidade, elaboram prestação de contas, contabilizam e arquivam a documentação enviada pela cantina, cooperativa e banco; registram alunos-funcionários, aprendem a escriturar fôlhas de pagamento, carteira profissional, horários de trabalho, cartas comerciais, ofícios e etc (SERVIÇO DO ENSINO VOCACIONAL, 1968a, p.159).

Essas atividades eram desenvolvidas dentro do Escritório nas seguintes seções: da estatística, do pessoal, de arquivo, de expediente, de contabilidade, de mimeografia e de correspondência. Segundo afirma o professor Gilberto,

[...] nós fazíamos isso em sala de aula com documentos reais: a nota fiscal da Cantina, que comprava os chocolates, da Cooperativa que tinha que pagar [...] e a contabilidade bancária, que era diferente na sua estruturação (ROVAI, 1996, p.228) ${ }^{61}$.

Quanto ao Acampamento, havia um preparo com os alunos para a realização desta atividade, que tinha por finalidade:

[...] 1) preparação de atitudes comportamentais durante o acampamento. Respeito pela pessoa humana. Sentido de cooperação e delicadeza. Esclarecimento sôbre serviços que são próprios aos sexos 2) trabalho com as alunas na preparação de possíveis problemas, tais como menstruação, cólicas, enurese noturna e sonambulismo [...] 3) trabalho com a equipefortalecer o sentido de cooperação e responsabilidade da equipe para o bom andamento ou funcionamento de todo o acampamento. Fortalecer o sentido de pertencer à equipe (SERVIÇO DO ENSINO VOCACIONAL, 1968a, p.162-3).

Era previsto também um trabalho de esclarecimento, por meio de palestras, sobre os objetivos do Acampamento com os pais. Estes eram alertados que possíveis problemas ocorridos no Acampamento seriam resolvidos em reuniões individuais, se necessárias.

\footnotetext{
${ }^{60}$ Esse trecho do texto de Balzan encontra-se no livro Ensino Vocacional. Uma Pedagogia Atual, publicado pela Editora Cortês em 2005 e organizado por Rovai.

${ }^{61}$ Esse trecho é parte do depoimento do ex-professor Gilberto A.Casolli, já mencionado anteriormente.
} 
Há um depoimento de ex-professora ${ }^{62}$ do Vocacional de São Paulo que chama a atenção para essa atividade. Ela se refere ao Acampamento, dizendo assim:

Não era bem acampamento, chamávamos de "acantonamento", porque [os alunos] não ficavam em barraca, ficavam em casa, em chalés. Mas eles iam para a cozinha, preparavam as refeições, serviam o almoço, o café, o jantar. Havia a equipe disso, a equipe daquilo (ROVAI, 1996, p.229).

No entanto, para que essa e outras atividades fossem realizadas, era necessária a intensa participação e integração de pais, comunidade e escola, o que era algo comum nas diferentes unidades Vocacionais.

A finalidade de todo este conjunto de Instituições desenvolvidas pela Equipe do Ensino Vocacional era proporcionar práticas que fizessem sentido no dia-a-dia dos alunos e familiares, com as quais pudessem vivenciar atividades comuns à vida social.

Após abordar as Instituições mencionadas anteriormente, o PPA trata de duas práticas pedagógicas de extrema importância na proposta do Ensino Vocacional: o Governo Estudantil e a Ação Comunitária.

Pelo fato do Ensino Vocacional ser uma proposta de escola renovada, há a necessidade absoluta de participação e atuação social. Neste contexto, surge como instrumento e técnica de educação o Governo Estudantil. Este,

[...] pela sua natureza institucional, vincula-se intrinsicamente [sic] à área de Estudos Sociais; como fonte de vivencias e experiências de atuação e participação, o Governo Estudantil se desenvolver também através das atividades de tôdas as áreas (SERVIÇO DO ENSINO VOCACIONAL, 1968a, p.188).

Apesar do volume considerável de informações presentes no PPA, não foi reservado espaço considerável para a apresentação minuciosa desta prática, muito embora ela seja freqüentemente mencionada no discurso dos ex-alunos do GVCP entrevistados nesta pesquisa, conforme será constatado ao final deste capítulo.

Quanto a Ação Comunitária, apresentava como principal objetivo o estímulo à participação consciente dos alunos na comunidade, segundo o nível de sua maturidade, buscando a melhoria das condições sociais. Na visão da Equipe Vocacional:

\footnotetext{
${ }^{62}$ Esse depoimento da professora Mariazinha encontra-se em (ROVAI, 1996).
} 
A responsabilidade da escola na comunidade é muito grande, pois ela deve ser o centro estimulador das mudanças que promovam a pessoal humana e, conseqüentemente, elevem o seu nível de vida. Para isto, precisa estar realmente inserida na comunidade, em constante comunicação com as pessoas e com as outras instituições. Precisa formar jovens capazes de desenvolver esta linha de ação - a de promover o bem comum, não agindo pelos outros, mas dando-lhes condições de se elevarem pela própria ação (SERVIÇO DO ENSINO VOCACIONAL, 1968a, p.190).

A Ação Comunitária, assim como o Acampamento e o Estudo do Meio, eram vivências fora da escola, sendo uma de suas finalidades reafirmar os conceitos e atitudes trabalhados pelos professores com os alunos em sala, bem como de os professores terem a oportunidade de observar o comportamento dos alunos em atividades fora da escola.

Segundo está definida no PPA, a Ação Comunitária:

[...] é um teste de grau de conscientização e responsabilidade, que os jovens alcançariam durante sua via escolar. De outro lado, ela testa, também, as aptidões e interesses de adolescentes, fornecendo dessa maneira, dados importantes para a Orientação Vocacional (SERVIÇO DO ENSINO VOCACIONAL, 1968a, p.193).

Os dois últimos temas da quarta parte do PPA a serem tratados aqui são: “Acompanhamento Pós-Escolar" e "Processo de Orientação Educacional e Vocacional".

Por Acompanhamento Pós-Escolar (A.P.E.) denominou-se o trabalho realizado com os alunos egressos dos Ginásios Vocacionais durante três anos consecutivos. Este acompanhamento:

[...] se caracteriza como faixa de aprofundamento da Orientação Vocacional, pois o desenvolvimento dos interêsses despertados no início da puberdade e adolescência continuam. [...] E como instrumento de avaliação, tendo em vista a obtenção de dados diversos, o A.P.E. se utiliza de instrumentos (SERVIÇO DO ENSINO VOCACIONAL, 1968a, p.270-1).

Tais instrumentos são assim listados:

1. questionário para ex-alunos (adaptação e evolução)

2. questionários para professôres

3. questionários para empregadores

4. formulários para alunos retidos e desistente. (SERVIÇO DO ENSINO

VOCACIONAL, 1968a, p.271) 
Dois aspectos são verificados durante o Acompanhamento Pós- Escolar:

1. aspecto de conteúdo - a adequação do conteúdo aprendido no ginásio vocacional, sua transferência para situações diferenciadas, o aprofundamento verificado.

2. aspecto das atitudes - compatíveis com os objetivos do ginásio vocacional: atitudes de trabalho (pesquisa, observação, análise) e atitudes sociais (responsabilidade, participação, cooperação, relacionamento com professor e colegas, etc) (SERVIÇO DO ENSINO VOCACIONAL, 1968a, p.271-2, grifos do autor).

Quanto ao processo de Orientação Educacional, o PPA esclarece que esta procura conhecer cada aluno, com sua personalidade única e em desenvolvimento, dotado de determinado potencial, que se expressa de determinada forma, e que desempenha no grupo social certos papeis, fruto das relações estabelecidas. Neste contexto, a função do orientador educacional é entrar em contato com os pais de alunos:

[...] levando-os a compreensão da adolescência em geral, dos seus filhos em particular, do sistema de ensino vocacional, sua filosofia, seus objetivos, métodos e técnicas, programando ação conjunta lar-escola. Sua ação se estende ainda fora da escola, quando planeja junto a outras instituições da comunidade ação paralela e ampliadora daquela desenvolvida no próprio ginásio. (SERVIÇO DO ENSINO VOCACIONAL, 1968a, p.274)

Em relação à Orientação Vocacional, o PPA a considera como a síntese de todo o processo de orientação desenvolvido nas quatro séries do Ginásio. Ele resulta de todo um processo educativo, cujos objetivos mantêm identidade de fins com os da educação, embora não se confundam com eles. Trata-se assim,

[...] de tôda uma ação conjunta de alunos, pais, professôres e orientadores. A percepção e a adesão dos objetivos educacionais propostos, o desenvolvimento dos conteúdos das diferentes áreas, a vivência das técnicas e a participação nas instituições didático-pedagógicas dão aos alunos possibilidades de conhecimento da realidade social, levam-nos à realização da "aprendizagem do eu", no dizer de Carl Rogers, e proporciona-lhes o treino de opções livres, sem o que impossível se faz a orientação vocacional como a conceituamos (SERVIÇO DO ENSINO VOCACIONAL, 1968a, p.285).

Finalizando esta breve apresentação de alguns tópicos que compõem o PPA, algumas considerações se fazem necessárias. A experiência dos Ginásios Vocacionais eve seu início de funcionamento no ano de 1962. Porém, somente em 1968 são elaborados seus 
Planos Pedagógicos e Administrativos (PPA). Esta demora na produção do documento nos remete a seguinte questão: seria o PPA um instrumento de avaliação da proposta de Ensino Vocacional? Tal demora seria justificada pelo fato da experiência Vocacional ser uma proposta de educação experimental, necessitando assim de aplicar as proposta e, somente em seguida, elaborar um documento que pudesse trazer os parâmetros de funcionamento e organização da experiência. Em função de sua extensão e riqueza de detalhes que apresenta, o PPA merece maiores investigações.

A seguir, dando continuidade a este capítulo, será tratado o GVCP nos seguintes aspectos: localização, organização e funcionamento, público alvo e práticas.

\subsection{Localização}

O GVCP de Batatais, no momento em que foi criado, não funcionou em um prédio próprio, especificamente construído para sua utilização. Umas das aprovações realizadas em 1961 pela “[...] Edilidade Batataense foi a autorização para contratar com o Fundo Estadual de Construção da Secretaria da Educação, a adaptação e construção do Ginásio Vocacional [...]” (FOLHA DE BATATAIS, 24 fev. 1961). E, como anteriormente mencionado, este foi inaugurado em março de 1962, no edifício onde funcionaria a Escola Industrial de Batatais ${ }^{63}$, localizado na Praça Coronel Nogueira, no bairro Castelo. Segundo publicação no Jornal "Folha de Batatais", sua "[...] localização reclama uma área mínima de 15 mil metros quadrados, o que dá bem idéia de sua importância” (19 fev. 1966).

A foto da Figura 5 ilustra bem a área da escola já construída. Verifica-se que realmente o espaço era amplo e contava com uma parte considerável para o desenvolvimento de atividades fora da sala de aula. Já em 1966, realizara-se um estudo para o início das obras de ampliação e conclusão do prédio, inclusive o levantamento de suas condições atuais e o de que necessitava para atender aos nétodos do Ensino Vocacional. De acordo com o jornal "Folha de Batatais" (24 jul. 1966), as seguintes obras deveriam ser feitas no Vocacional: “[...] construção de novas salas de aula, novo refeitório, salas de estudo, um moderno conjunto para o setor administrativo da escola, e possivelmente o muro que circundará toda a Praça Coronel Nogueira, além de outros melhoramentos". Neste mesmo ano, a equipe deste Vocacional foi

\footnotetext{
${ }^{63}$ Essa escola foi criada pela Lei no. 2438, em 22 de dezembro de 1953.
} 
recebida na residência do Dr. José Olimpio Freiria, então Prefeito Municipal de Batatais, para uma reunião na qual foram tratados assuntos relacionados:

[...] com uma gleba de terra para ser doada ao Ginásio Vocacional: este terreno destina-se às aulas de Práticas Agrícolas e nele deverá ser construído um barracão para abrigar as máquinas e ferramentas agrícolas da escola (FOLHA DE BATATAIS, 24 jul. 1966).

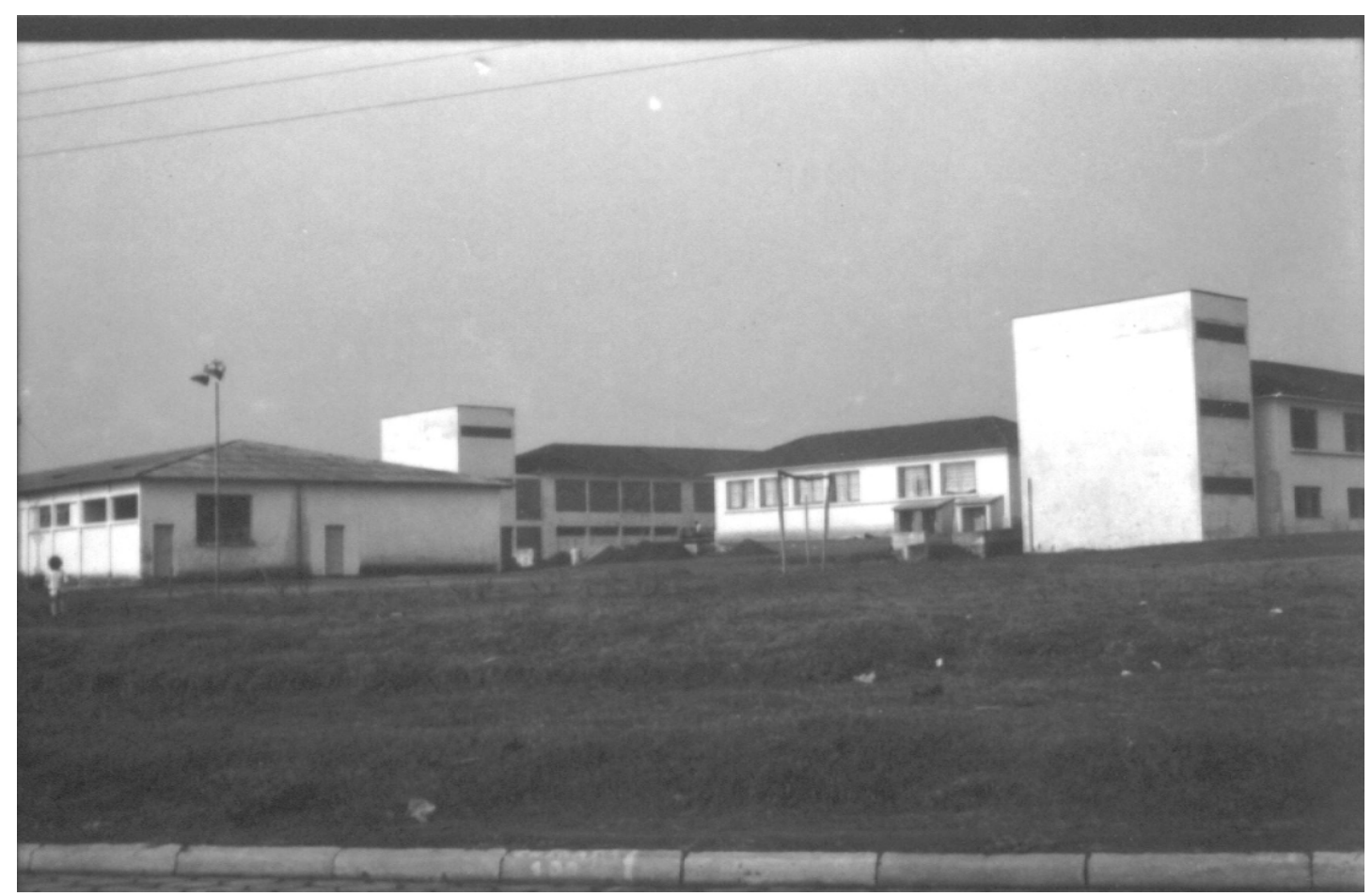

Figura 5. Prédio do Ginásio Vocacional “Cândido Portinari” (1962). Fonte: Arquivo do GVCP.

Cabe ressaltar que quase todos os Ginásios Vocacionais tiveram suas localizações em áreas centrais ou próximas de centros importantes da cidade. Por exemplo, a unidade da capital localizada no bairro do Brooklin e a própria unidade de Batatais. Estamos chamando atenção para esse aspecto porque não se pode desconsiderar o lugar ocupado pela escola no espaço urbano, ou seja, “[...] não apenas o espaço-escola, mas também sua localização, a disposição dele na trama urbana dos povoados e cidades, tem de ser examinado como um elemento curricular" (ESCOLANO, 1998).

Uma outra questão relevante, e que merece investigação, diz respeito à própria localização e distância das cidades do interior do estado em relação à capital. Das cinco unidades instaladas tem-se: Barretos, como a cidade mais distante da capital $(475 \mathrm{Km}$ de São Paulo); Batatais a 355 Km; Rio Claro a 173 Km; Americana a 138 Km; e, por última, 
São Caetano do Sul, a somente $12 \mathrm{Km}$ da capital. Seria interessante pensar qual foi a lógica (se foi intencional ou não) desse mapa das unidades.

\subsection{Organização e Funcionamento}

No que concerne à organização e funcionamento do GVCP, seu Regimento Interno apresenta 33 objetivos que fundamentam as finalidades da instituição. Destes, destacam-se três que se categorizavam como objetivos de conhecimento e comportamento, tendo em vista o desenvolvimento da personalidade do adolescente e das aptidões a partir da orientação vocacional e profissional:

[...] preparar o adolescente para bons ajustamentos pessoais e sociais diante das necessidades imediatas do trabalho; [...] conduzir à elaboração dos conteúdos de conhecimento e formação de atitudes mentais e sociais atravéz [sic] de técnicas que proporcionem real incorporação dos mesmos ao patrimônio da personalidade do adolescente; [...] levar alunos, professôres [sic], pais e demais membros da comunidade à compreensão de que a escola deverá ser o centro: onde se reúnam todos os esforços das famílias que moram a seu redor e cujos filhos a freqüentam; onde se faça o processo de integração de grupos atravéz [sic] da ação dos educadores, pais e dos próprios alunos; para onde convirjam as realizações de outros grupos ou instituições e onde partam os resultados dessa conversão (SERVIÇO DO ENSINO VOCACIONAL, 1968b, p.2).

A escola funcionava em período integral, dispunha de um refeitório e uma cozinha adaptada, além uma sala de aula que simulava um ambiente doméstico, onde se desenvolviam as atividades de orientação em Educação Doméstica ${ }^{64}$. Esse aspecto contribuía para que a vivência dos alunos junto de seus colegas e professores extrapolasse os muros da escola e fizessem dela a extensão de seus lares.

Com já mencionado anteriormente, um dos pontos importantes da pedagogia do Ensino Vocacional era o envolvimento dos pais, alunos, professores e da própria comunidade na escola, o que resultou na organização da Sociedade de Pais e Amigos do Vocacional e na elaboração de programas tais como:

\footnotetext{
${ }^{64}$ Essa atividade será relatada com mais detalhes no item "Práticas do GVCP".
} 
[...] a) palestras para alunos; b) palestras para professôres [sic]; c) colaboração no estudo do meio; e d) colaboração no levantamento de mercado de trabalho para os jovens. [...] [Ainda era parte do programa oferecer] assistência às promoções sociais e culturais das Sociedades; [e fazer uma] programação conjunta para previsão de recursos matérias (reformas, conservação e equipamento, material didático, pagamento de funcionários burocráticos e braçais) e respectivos- planos de aplicação (SERVIÇO DO ENSINO VOCACIONAL, 1968c, p.194).

Tal envolvimento com a comunidade também tinha sua recíproca, uma vez que o Vocacional acabava por prestar:

Assistência aos grupos de teatro e da sociedade Pró-Artes de Batatais nos seus programas e realizações das quais participam jovens das várias escolas secundárias, profissôres [sic], pais de alunos e músicos da comunidade (SERVIÇO DO ENSINO VOCACIONAL, 1968c, p.206).

No caso de Batatais, esta ação comunitária levou os alunos do GVCP a desenvolver um trabalho tanto na zona rural quanto na urbana. Os alunos organizaram questionários a serem aplicados nessas comunidades como forma de levantarem problemas e linhas de atuação.

As questões formuladas focalizavam: "1. o trabalhador rural; 2. o proprietário da fazenda; 3. as instituições da comunidade; e 4. o trabalhador rural volante (Vila Maria e Vila Cruzeiro)" (SERVIÇO DO ENSINO VOCACIONAL, 1968c, p.194). Nesse caso, mais especificamente sobre o trabalhador rural, procurou-se saber sobre as necessidades de sobrevivência, as condições de trabalho, salário e sua utilização, bem como problemas relacionados com a educação dos filhos e sanitários. Assim, terminadas as visitas e a aplicação dos questionários, os alunos buscaram analisar os resultados com a intenção de programar melhor suas atuações. Os alunos:

[...] optaram por trabalhar junto à Unidade Rural Pilôto [sic], ao Clube Agrícola e por dar colaboração à ação comunitária do pároco das Vilas Maria e Cruzeiro, [mas realizaram essa atividade] [...] ao lado da assistente social e da visitadora sanitária (SERVIÇO DO ENSINO VOCACIONAL, 1968c, p.196).

Outra atividade que contava muito com a colaboração da comunidade Vocacional (pais, professores, diretores e orientadores) era o acampamento, realizado em todo o processo de escolarização. Essa atividade visava: 
[...] reafirmação de conceitos e atitudes através da prática, oportunidade de observar os alunos em atividades mais livres, para colhêr [sic] informações e poder atuar em orientação de grupo ou entrevista individual durante o período posterior (SERVIÇO DO ENSINO VOCACIONAL, 1968c, p.90).

O desenvolvimento dessa atividade pode ser visto nas fotos que serão apresentadas no final deste capítulo, no item 3.5.

\subsection{Público Alvo}

Para tratar do público alvo do GVCP - seus alunos - é importante refletir sobre quem eram esses jovens, suas orige ns familiares, etnias, religiões e composições etárias. Mais do que isso, é pensar que juventude está se abordando e, ainda, qual o papel da família na escolarização desses jovens? Quem teria acesso a essa instituição? Quais seriam os critérios de seleção das matrículas do GVCP? Essas são questões difíceis de precisar, mas procurou-se neste trabalho elaborar a caracterização dos alunos dessa escola com o intuito de revelar dados sobre o possível favorecimento, ou não, de determinados grupos sociais durante seu funcionamento.

De acordo com o PPA, um dos critérios para o ingresso dos alunos nos Ginásios Vocacionais era o exame de admissão:

Êle se faz necessário em virtude de ter o Ginásio Vocacional uma estrutura diferente dos demais ginásios e introduzir quase que anualmente, algumas modificações no sistema de seleção de candidatos. A fim de não onerar os professôres e desejando também que alunos e pais participem do processo, organiza-se com êles o serviço de informações no qual deve se destacar duas faixas de atuação:

- a primeira - dos alunos de primeira e segunda séries, que vão aos grupos escolares ao encontro dos alunos de quarto e quinto anos primários, para lhes explicar, numa forma de linguagem mais próxima, o que é o Ginásio Vocacional e quais as condições para nêle se inscrever.

- a segunda - dos pais de alunos que, nos seus ambientes de trabalho, procuram esclarecer seus colegas e amigos a respeito dos exames de admissão (SERVIÇO DO ENSINO VOCACIONAL, 1968a, p.323-4).

No caso do GVCP, a divulgação de seu início de funcionamento, segundo Pinho (1983), deu-se por meio de grande utilização “[...] dos meios de comunicação de massa, como rádio e jornais" (p.102). Com o decorrer dos anos, o número excessivo de inscritos levou a Equipe do Vocacional a utilizar, além do exame de admissão, entrevistas como mais 
um recurso para selecionar os candidatos. Sobre isto, o Vocacional publica uma nota no jornal "Folha de Batatais" informando:

Acham-se abertas de 25 de outubro a 10 de novembro, das 8 às 11 e das 13 às 16 horas, as inscrições de candidatos às provas de seleção para a $1^{\mathrm{a}}$. série ginasial, no Ginásio Estadual Vocacional 'Cândido Portinari' de Batatais, sito à rua D. Bosco. As provas escritas terão lugar nos dias 6, 7, 9 e 10 de dezembro, no período da tarde e as entrevistas serão realizadas em novembro (31 out. 1965).

É importante salientar também que o SEV já havia determinado que o “[...] candidato deve[ria] ter nascido no período compreendido entre $1^{\circ}$. de janeiro de 1949 até 31 de dezembro de 1950 [...]" (FOLHA DE BATATAIS, 25 nov. 1962). Isto significa que os candidatos deveriam ter entre 11 e 13 anos de idade no momento da inscrição. Este fato certamente muito contribuiu para a seletividade de todo o processo, considerando que nesta época a número de jovens fora da série correspondente a sua idade deveria ser considerável.

Segundo Rovai (2005), esses jovens, em sua maioria, eram:

[...] jovens "privilegiados", não no sentido socioeconômico, pois os alunos, principalmente aqueles das primeiras turmas, atraídos pelo nome "vocacional" e identificado-o com uma "escola profissional", eram oriundos de camadas socioeconômicas média, média/baixa ou baixa (ROVAI, 2005, p.16).

É possível inferir que os jovens atendidos nos Vocacionais eram privilegiados pelo fato de, ainda nesse período, esta modalidade de ensino não ser colocada como direito pelo Ensino Secundário, e nem a escola de tempo integral estar contempladas na lei.

Uma nova nota no jornal "Folha de Batatais" informa a criação de mais um elemento para o processo de ingresso no GVCP:

A Sociedade de Amigos do Ginásio Estadual Vocacional 'Cândido Portinari' patrocinará, neste semestre, a partir de $1^{\circ}$. de setembro, um curso intensivo de admissão ao Ginásio, que deverá funcionar no prédio do Ginásio Vocacional, de $2^{\mathrm{a}}$. a $6^{\mathrm{a}}$.-feira, das 18.30 horas às 20.30 horas. As aulas serão ministradas por professoras primárias, alunas do curso de Aperfeiçoamento, interessadas em renovação do ensino. Os alunos candidatos à $1^{\mathrm{a}}$. série, já serão introduzidos em algumas das modernas técnicas de ensino adotadas no Ginásio Vocacional, como também serão iniciadas numa nova abordagem das áreas de ensino, como por exemplo: a matemática moderna. As 
inscrições estarão abertas, no Ginásio Vocacional, neste mês, de $2^{\mathrm{a}}$. a $6^{\mathrm{a}}$.feira, das 8 às 11.30 horas, para o preenchimento de 65 vagas (26 ago. 1966).

Dois pontos importantes a serem refletidos a partir desta nota: em primeiro lugar, a mobilização da comunidade (dos pais) com o intuito de oferecer aos filhos uma ajuda no processo de ingresso; em segundo, este curso de admissão pode ser compreendido como um outro instrumento de seleção dos candidatos ao Vocacional.

Uma vez explicitado o processo de ingresso, será caracterizado o público algo desta instituição, tendo como base as informações contidas no Livro de Matrícula ${ }^{65}$, tais como: idade, série, filiação, profissão e nacionalidade dos pais. Não há um campo específico contendo a informação sobre o sexo do aluno, o que obrigou a diferenciação (mesmo que inexata) apenas pelo nome. A Tabela 3 reúne a soma realizada, apresentando o número de alunos do GVCP por sexo e por ano.

Tabela 3 - Número de alunos por ano no GVCP.

\begin{tabular}{|c|c|c|c|c|c|}
\hline \multirow{2}{*}{ Ano } & Número & \multicolumn{4}{|c|}{ Alunos } \\
\cline { 3 - 6 } & de Alunos & Meninos & \% & Meninas & \% \\
\hline $\mathbf{1 9 6 7}$ & 255 & 191 & 75 & 64 & 25 \\
\hline $\mathbf{1 9 6 8}$ & 273 & 209 & 77 & 64 & 23 \\
\hline $\mathbf{1 9 6 9}$ & 276 & 199 & 72 & 77 & 28 \\
\hline
\end{tabular}

Fonte: Livro de Matrícula de 1967-1969 do Ginásio Estadual Vocacional "Cândido Portinari”.

Do total de alunos matriculados no GVCP, nos anos abordados na Tabela 3, observa-se um número muito superior de meninos em relação ao número de meninas. Apesar de se constatar uma variação percentual no decorrer dos anos (chegando em 5\% entre os anos de 1968 e 1969), a predominância do sexo masculino permanece muito significativa. Provavelmente a identificação do Ensino Vocacional como uma "escola profissional", já citada anteriormente a partir do texto de Rovai (2005), tenha favorecido a maior presença do público masculino.

A Tabela 4 apresenta a somatória de meninos e meninas em diferentes faixas etárias, entre os anos de 1967 a 1969. Pela disposição dos dados nesta tabela percebe-se uma diminuição da idade de entrada dos alunos com o passar dos anos e que a limitação de idade

\footnotetext{
${ }^{65}$ Foram utilizadas apenas as informações contidas no Livro de Matricula referente aos anos de 1967 a 1969. Isto porque o Livro de Matrícula de 1962 a 1965 não foi encontrado e as informações relativas ao ano de 1966 estavam incomp letas.
} 
para ingresso (entre 11 e 13 anos) inicialmente imposta pelo SEV não foi mais adotada no GVCP.

Diferentemente do que se observa na Tabela 3, que se refere à totalidade dos alunos do GVCP, na Tabela 4 observa-se um aumento significativo do número de meninas e uma diminuição também significativa do número de meninos com o passar dos anos. Este fato pode ser entendido como uma descaracterização da proposta do Ginásio Vocacional enquanto “escola profissional” perante a comunidade. Ou então que a Equipe Vocacional tenha feito um esforço em promover a equidade dos sexos dos matriculados no GVCP, o que não invalida a primeira hipótese mencionada.

Tabela 4 - Idades de meninos e meninas da 1ª́rie do GVCP (1967 a 1969).

\begin{tabular}{|c|c|c|c|c|c|c|c|c|c|c|c|c|}
\hline \multirow{3}{*}{ Idade } & \multicolumn{12}{|c|}{ Anos } \\
\hline & \multicolumn{4}{|c|}{1967} & \multicolumn{4}{|c|}{1968} & \multicolumn{4}{|c|}{1969} \\
\hline & meninas & $\%$ & meninos & $\%$ & Meninas & $\%$ & meninos & $\%$ & meninas & $\%$ & meninos & $\%$ \\
\hline 9 anos & & & & & & & & & 11 & 33 & 14 & 23 \\
\hline 10 anos & & & & & 12 & 43 & 16 & 25 & 15 & 45 & 24 & 39 \\
\hline 11 anos & 4 & 27 & 18 & 24 & 8 & 29 & 18 & 28 & 7 & 21 & 18 & 29 \\
\hline 12 anos & 6 & 40 & 31 & 41 & 7 & 25 & 24 & 37 & & & 6 & 10 \\
\hline 13 anos & 4 & 27 & 20 & 26 & & & 3 & 5 & & & & \\
\hline 14 anos & & & 6 & 8 & & & & & & & & \\
\hline $\begin{array}{l}\text { Não } \\
\text { Identificado }\end{array}$ & 1 & 7 & 1 & 1 & 1 & 4 & 4 & 6 & & & & \\
\hline $\begin{array}{l}\text { Total de } \\
\text { alunos }\end{array}$ & 15 & 100 & 76 & 100 & 28 & 100 & 65 & 100 & 33 & 100 & 62 & 100 \\
\hline
\end{tabular}

Fonte: Livro de Matrícula de 1967-1969 do Ginásio Estadual Vocacional “Cândido Portinari”.

Os dados da Tabela 4 permitem supor também a dificuldade de homogeneização das classes que nos remete a alguns questionamentos: os professores deveriam enfrentar problemas de adequação das lições com classes compostas por alunos de idades consideravelmente variadas? Essa questão, apesar de muito provavelmente ter sido relevante no processo de ensino-aprendizagem, não foi citada, muito menos apontado como problema nos trabalhos produzidos sobre o tema "Ginásios Vocacionais".

Após apresentar a caracterização dos alunos do GVCP, segue-se com uma breve identificação dos pais de alunos deste Vocacional, por considerar tal informação importante para esta pesquisa.

Um primeiro aspecto analisado a respeito dos pais de alunos do GVCP é a nacionalidade. A imensa maioria dos pais, como já era de se supor, é composta de brasileiros. Porém, outras nacionalidades aparecem de forma diminuta no Livro de Matricula, tais como: espanhola, japonesa, americana, argentina e inglesa. 
O aspecto mais significativo para a caracterização dos pais é a profissão, o que levou a elaboração da Tabela 5, que lista as principais profissões mencionadas, com as respectivas porcentagens com que as mesmas aparecem no decorrer dos anos de 1967 a 1969.

De modo geral, observa-se uma grande variedade de profissões nas mais diversas áreas, o que indica a representação de todo o espectro social da época. Porém, isso não significa, em termos percentuais, uma distribuição igualitária das matrículas por entre as classes sociais, muito menos se for considerada uma distribuição proporcional.

As duas profissões que mais foram citadas no Livro de Matricula foram "Comerciante" e "Agricultor", que para a análise aqui realizada são justamente as que trazem maior ambigüidade. Se por um lado "Comerciante" é entendido como o proprietário de estabelecimento(s) comercial(is), este termo pode ter sido utilizado para designar "Comerciário", ou seja, aquele que trabalha como empregado no comercio. Já o termo "Agricultor", a primeira vista designa um pequeno proprietário de terras. Porém, pode também ter sido utilizado para designar "Trabalhador Rural”, uma vez que este não foi citado em nenhum momento no Livro de Matricula. A escolha entre os significados depende da interpretação dada pelo funcionário da secretaria da escola no momento do preenchimento dos dados.

Se forem consideradas apenas as primeiras definições dos dois termos anteriores, tem-se, no ano de $1968^{66}$, aproximadamente $70 \%$ dos pais com profissões identificadas com as classes média e média-alta. Caso contrário, se forem levadas em consideração as observações mencionadas a respeito da interpretação dos termos, neste mesmo ano, ainda sim se tem uma porcentagem significativa desta parcela da sociedade.

Estas informações apontam para a seguinte hipótese: apesar dos Ginásios Vocacionais serem um modelo de escola pública, dita "comunitária" e pensada para atender toda a sociedade, o GVCP atendeu em grande parte a parcela de maior poder aquisitivo da sociedade. Ou seja, os dados da Tabela 5 indicam que, apesar do GVCP não ter sido pensado para a elite, acabou se tornando uma escola da elite. Isto leva a outra hipótese: o fato dos Ginásios Vocacionais apresentarem uma proposta renovadora de ensino para a época foi um atrativo para a elite da sociedade. A confirmação destas hipóteses depende de dados referentes aos demais anos da experiência em Batatais, o que não se encontra disponível até o momento da elaboração desta pesquisa.

\footnotetext{
${ }^{66}$ A escolha em analisar particularmente os dados de 1968 se justifica pelo fato do número de "Não Consta" neste ano ser o menor dentre os anos apresentados.
} 
Tabela 5 - Profissões dos pais dos alunos do GVCP (1967 a 1969).

\begin{tabular}{|c|c|c|c|c|c|c|c|c|c|c|c|c|}
\hline \multirow{2}{*}{ Profissões ${ }^{67}$} & \multicolumn{4}{|c|}{1967} & \multicolumn{4}{|c|}{1968} & \multicolumn{4}{|c|}{$1969^{68}$} \\
\hline & Pai & $\%$ & Mãe & $\%$ & Pai & $\%$ & Mãe & $\%$ & Pai & $\%$ & Mãe & $\%$ \\
\hline Comerciante & 45 & 17,6 & & & 45 & 16,4 & 2 & 0,7 & 20 & 7,2 & & \\
\hline Agricultor & 37 & 14,5 & & & 43 & 15,6 & & & 30 & 10,9 & & \\
\hline Funcionário Público & 16 & 6,3 & 9 & 3,5 & 18 & 6,5 & 7 & 2,5 & 15 & 5,4 & & \\
\hline Médico & 13 & 5,1 & & & 23 & 8,4 & 2 & 0,7 & 8 & 2,9 & & \\
\hline Bancário & 12 & 4,7 & & & 10 & 3,6 & & & 4 & 1,4 & & \\
\hline Fazendeiro & 7 & 2,7 & & & 9 & 3,3 & & & 1 & 0,4 & & \\
\hline Industrial & 7 & 2,7 & & & 6 & 2,2 & & & 3 & 1,1 & & \\
\hline Professor & 6 & 2,4 & 41 & 16,1 & 13 & 4,7 & 51 & 18,5 & 2 & 0,7 & & \\
\hline Advogado & 6 & 2,4 & & & 9 & 3,3 & & & 3 & 1,1 & & \\
\hline Engenheiro & 5 & 2,0 & & & 9 & 3,3 & & & 1 & 0,4 & & \\
\hline Motorista & 5 & 2,0 & & & 5 & 1,8 & & & 3 & 1,1 & & \\
\hline Pedreiro & 5 & 2,0 & & & 7 & 2,5 & & & 4 & 1,4 & & \\
\hline Dentista & 4 & 1,6 & 1 & 0,4 & 9 & 3,3 & 1 & 0,4 & 2 & 0,7 & & \\
\hline Mecânico & 4 & 1,6 & & & 4 & 1,5 & & & 4 & 1,4 & & \\
\hline Eletricista & 3 & 1,2 & & & 4 & 1,5 & & & 1 & 0,4 & & \\
\hline Marceneiro & 3 & 1,2 & & & 3 & 1,1 & & & & & & \\
\hline Viajante & 3 & 1,2 & & & 7 & 2,5 & & & 2 & 0,7 & & \\
\hline Contador & 2 & 0,8 & 1 & 0,4 & 1 & 0,4 & 1 & 0,4 & 1 & 0,4 & & \\
\hline Balconista & 2 & 0,8 & & & 1 & 0,4 & & & & & & \\
\hline Jornalista & 2 & 0,8 & & & & & & & & & & \\
\hline Farmacêutico & 1 & 0,4 & 1 & 0,4 & 2 & 0,7 & 1 & 0,4 & 1 & 0,4 & & \\
\hline Operário & 1 & 0,4 & & & 1 & 0,4 & & & 5 & 1,8 & & \\
\hline Comerciário & 1 & 0,4 & & & 2 & 0,7 & & & 3 & 1,1 & & \\
\hline Doméstica & & & 150 & 58,8 & & & 187 & 68,0 & & & & \\
\hline Costureira & & & 3 & 1,2 & & & 1 & 0,4 & & & & \\
\hline Cabeleireira & & & 2 & 0,8 & & & 2 & 0,7 & & & & \\
\hline Padeiro & & & & & 2 & 0,7 & & & 2 & 0,7 & & \\
\hline Outras $^{69}$ & 14 & 5,5 & 4 & 1,6 & 26 & 9,5 & 3 & 1,1 & 9 & 3,3 & 0 & \\
\hline Falecido & 3 & 1,2 & 1 & 0,4 & 3 & 1,1 & & & 5 & 1,8 & 1 & 0,4 \\
\hline Não Consta & 48 & 18,8 & 42 & 16,5 & 13 & 4,7 & 17 & 6,2 & 147 & 53,3 & 275 & 99,6 \\
\hline Total & 255 & 100 & 255 & 100 & 275 & 100 & 275 & 100 & 276 & 100 & 276 & 100 \\
\hline
\end{tabular}

Fonte: Livro de Matrícula de 1967-1969 do Ginásio Estadual Vocacional “Cândido Portinari”.

\footnotetext{
${ }^{67}$ Esta tabela foi organizada com base na classificação das profissões constantes no Livro de Matrícula de 1967 a 1969.

${ }^{68}$ Os dados sobre a profissão, referentes ao ano de 1969, não foram devidamente preenchidos no Livro de Matrícula, o que explica o grande número de "Não Consta".

${ }^{69}$ No termo "Outras" encontram-se agrupadas as profissões que apareceram em menor número, quando comparadas às demais. Foram mencionadas profissões tais como: alfaiate, almoxarife, bibliotecário, carpinteiro, celeiro, cinematógrafo, diretor de finanças, economista, encanador, enfermeiro, escrivão, feitor, mestre cervejeiro, militar, pianista, pintor, protético, relojoeiro, sapateiro, chofer de praça, tecelão, técnico industrial, telefonista, topógrafo, dentre outras.
} 
Uma última observação a respeito dos dados da Tabela 5 é quanto ao termo "Doméstica". Este termo consta no Livro de Matrícula, provavelmente, designando tanto a profissão de empregada doméstica (esta certamente em muito menor número) quanto a mulher do lar ou a mulher que não possuía profissão. Este fato pode ser inferido observandose a profissão do cônjuge.

\subsection{As Práticas no GVCP}

Neste item serão tratadas as práticas desenvolvidas no Vocacional de Batatais relatadas nas entrevistas com seus ex-alunos. Tais práticas serão analisadas sob a ótica do PPA - documento apresentado no inicio deste capítulo - e das fotografias registradas sobre a experiência. A ordem de descrição das práticas será semelhante à utilizada no roteiro de entrevistas. Este roteiro foi composto de quinze questões, sendo: três relativas ao processo de ingresso dos alunos no GVCP; duas referentes aos pais, suas profissões e participação na Associação de Pais do Vocacional; cinco focalizando as práticas no GVCP; e cinco sobre o significado da experiência para os ex-alunos. Apesar de nem todas as questões abordarem diretamente as práticas, a maioria dos entrevistados acabam por mencioná-las em suas respostas.

As atividades citadas pelos ex-alunos foram: Trabalho em Equipe, Estudo do Meio, Banco, Escritório Contábil, Cantina, Cooperativa, Acampamento, Governo Estudantil, Economia Doméstica e Práticas Agrícolas. Além disso, as entrevistas apontaram para: a relação entre alunos, professor e aluno e a Orientação Vocacional.

Uma menção sempre presente nos discursos dos ex-alunos entrevistados foi a utilização do Trabalho em Equipe em todas as atividades vivenciadas no GVCP. Oito dos nove alunos entrevistados fizeram questão de abordar esta prática. Segundo o ex-aluno J.O. ${ }^{70}$ (02 nov. 2005), “[...] tudo no Vocacional era realizado em equipe”. Tais equipes “[...] eram formadas de quatro a cinco elementos, dependendo da quantidade de alunos por classe" (R.O, 17 nov. 2006). Cada equipe “[...] tinha o líder e essa liderança era revezada para explorar, trabalhar a liderança e a individualidade de cada um" (P.I., 17 nov. 2006). Estas informações

\footnotetext{
${ }^{70}$ Optou-se por utilizar apenas as letras iniciais dos nomes dos ex-alunos entrevistados, seguido da data em que a entrevista foi realizada.
} 
vêm ao encontro tanto do que se buscou registrar nas fotos das Figuras 6 e 7, quanto ao que se apontou no PPA.

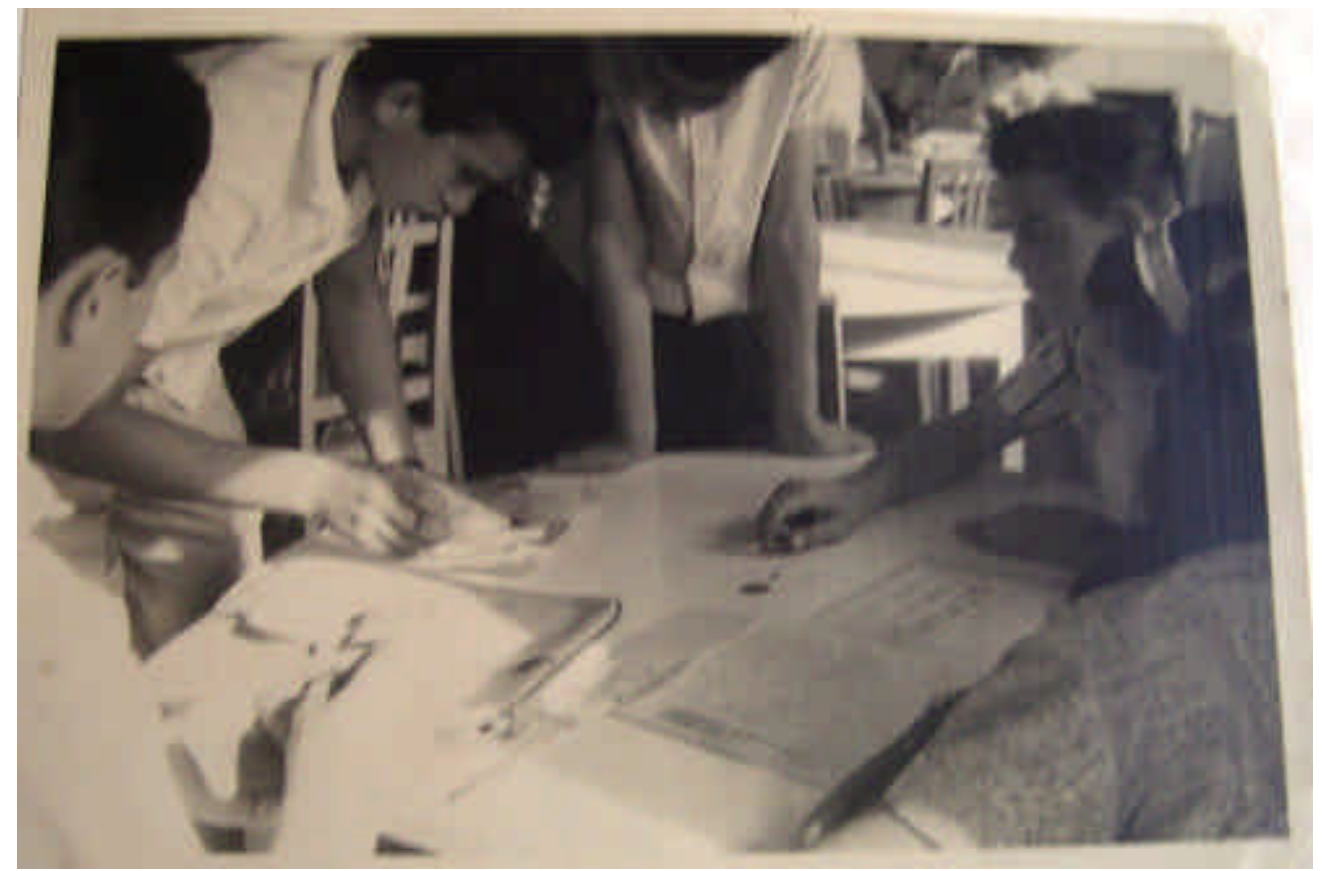

Figura 6. Trabalho em Equipe no GVCP: prática constante.

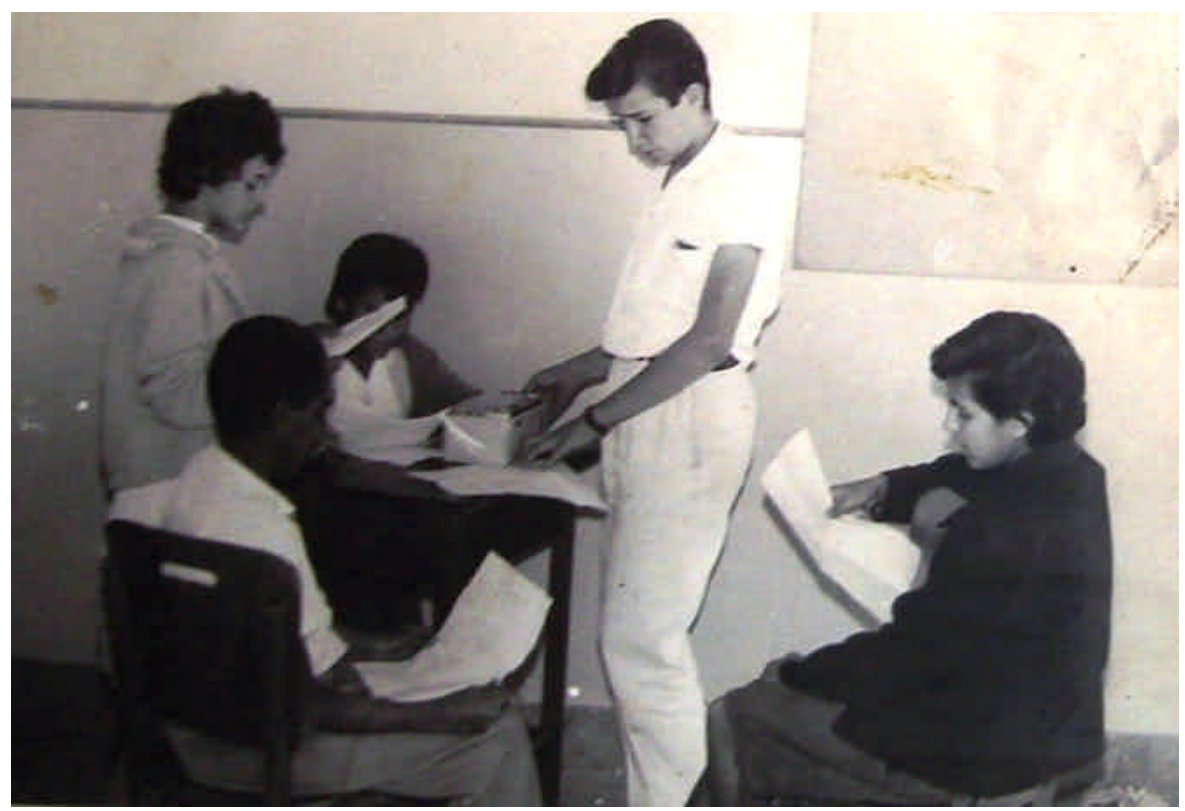

Figura 7. Trabalho em Equipe no GVCP: grupos de trabalhos mistos.

A prática mais mencionada pelos ex-alunos entrevistados foi o Estudo do Meio. O ex-aluno R.E. afirma que em todas as aulas do GVCP se fazia o Estudo do Meio: "[...] a gente ia in loco, fazia o trabalho a partir da situação que provocava a teoria" (31 out. 2005). Assim, “[...] quando se falava de uma fazenda de café, a gente tinha aquela visão de 
uma fazenda de café e depois a gente ia fazer uma visita numa fazenda de café." (R.O., 17 nov. 2006). A Figura 8 parece ilustrar esta situação.

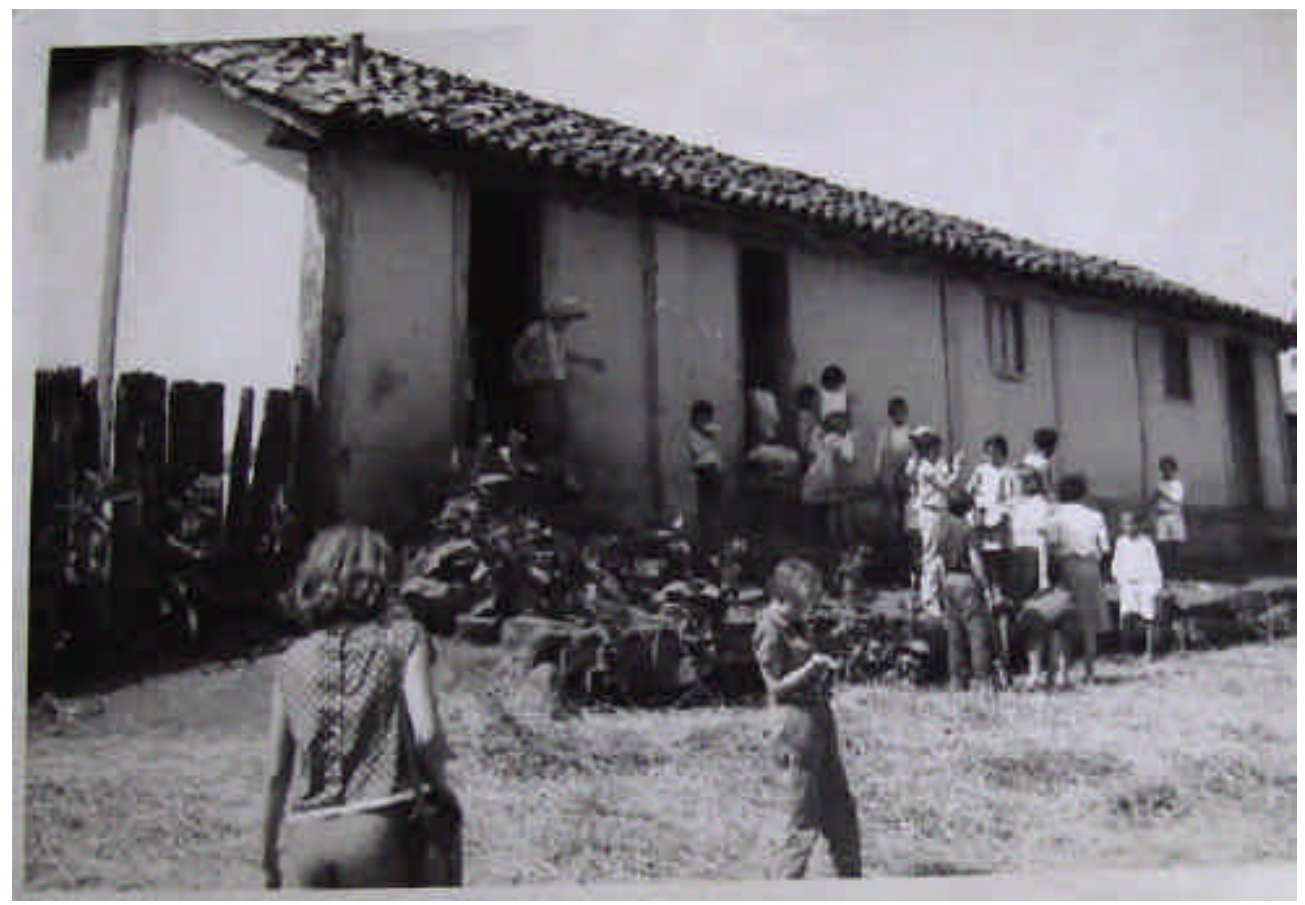

Figura 8. Estudo do Meio no GVCP: visita à fazenda de café.

Além disso, '[...] quando você saía pra uma viagem, já tinha estudado tudo praticamente na parte teórica, depois você ia a campo" (R.E., 17 nov. 2006).

De acordo com o PPA e também com os ex-alunos entrevistados, essa atividade era organizada por série:

[...] no primeiro ano, quando [se] estudava o município, fazíamos viagens por aqui, ia à fazenda, ia visitar a indústria [...] No segundo ano, nós estávamos estudando o estado, então nós fomos à Franca, visitar a indústria de calçados, fomos para São Paulo (J.M., 17 nov. 2006).

No percurso dessa viagem a cidade de Franca:

[...] a gente tava interligando todo o conhecimento, toda a matéria. Então você via a natureza. Na natureza você via Práticas Agrícolas. Dentro de Práticas Agrícolas tudo que você via, desde o relevo, das plantações, tipo de animais. Você via até a parte matemática, tinha que fazer cálculo pra ver qual era a dimensão daquela área plantada e até a gente era obrigada a desenhar o animal que você via no caminho (J.O., 02 nov. 2005). 
Tal viagem ficou registrada na foto apresentada na Figura 9.

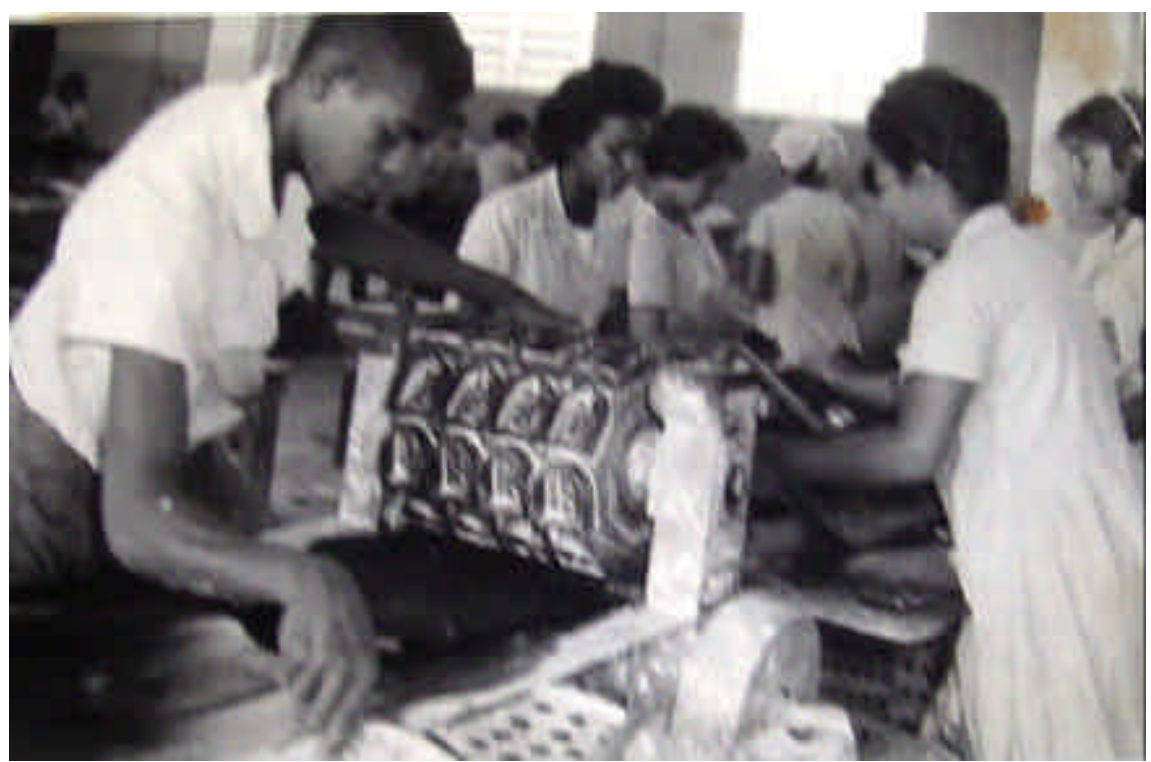

Figura 9. Estudo do Meio no GVCP: visita à fábrica de calçados, na cidade de Franca.

As atividades da Cantina, Cooperativa, Banco, Escritório Contábil e Acampamento fazem parte de um conjunto de práticas que foram denominadas como “Instituições Didático-Pedagógicas” pelo PPA. Tais instituições foram mencionadas por cinco dos nove alunos entrevistados. Um ex-aluno afirmou, por exemplo: ' [...] a gente aprendeu a trabalhar com banco, com cooperativa, datilografia - porque na época não existia computador - [...] a gente aprendeu a fazer cheque" (A.A., 01 nov. 2005).

Duas passagens dos discursos dos ex-alunos ilustram como estas instituições marcaram profundamente suas vivências no GVCP. Um primeiro afirmou: “[...] me lembro muito bem das cantinas, do banco, da gente preencher cheque. Isso é uma coisa... assim... que eu me lembro quando hoje a gente preenche...” (R.E., 31 out. 2005). Já um segundo ex-aluno completa:

[...] aprender a escrever à máquina pra nós era uma maravilha porque [eu] era muito jovem ainda, eu tava com onze anos e já aprender a bater à máquina, naquela época, era muito. [...] Uma outra coisa que não esqueço de jeito nenhum que quando chegava na época do Natal ou alguma outra época tinha sempre o amigo invisível. Ele [o professor] fazia você bater à máquina, escrever para um amigo, [...] essas coisas a gente não esquece de jeito nenhum [...] (R.A., 17 nov. 2006).

Quanto a Cooperativa, um ex-aluno comenta: 
[...] nós tínhamos a Cooperativa, onde comprávamos lápis, caderno, [...] nós comprávamos na Cooperativa e tínhamos aula de Práticas Comerciais, aprendíamos matemática, a fazer a contabilidade. Então é muito interessante isso... O Vocacional [nos] formou bem... (J.M., 17 nov. 2006)

As fotos das Figuras 10 e 11 registram, respectivamente, uma aula de datilografia no GVCP e o trabalho na Cooperativa deste Vocacional.

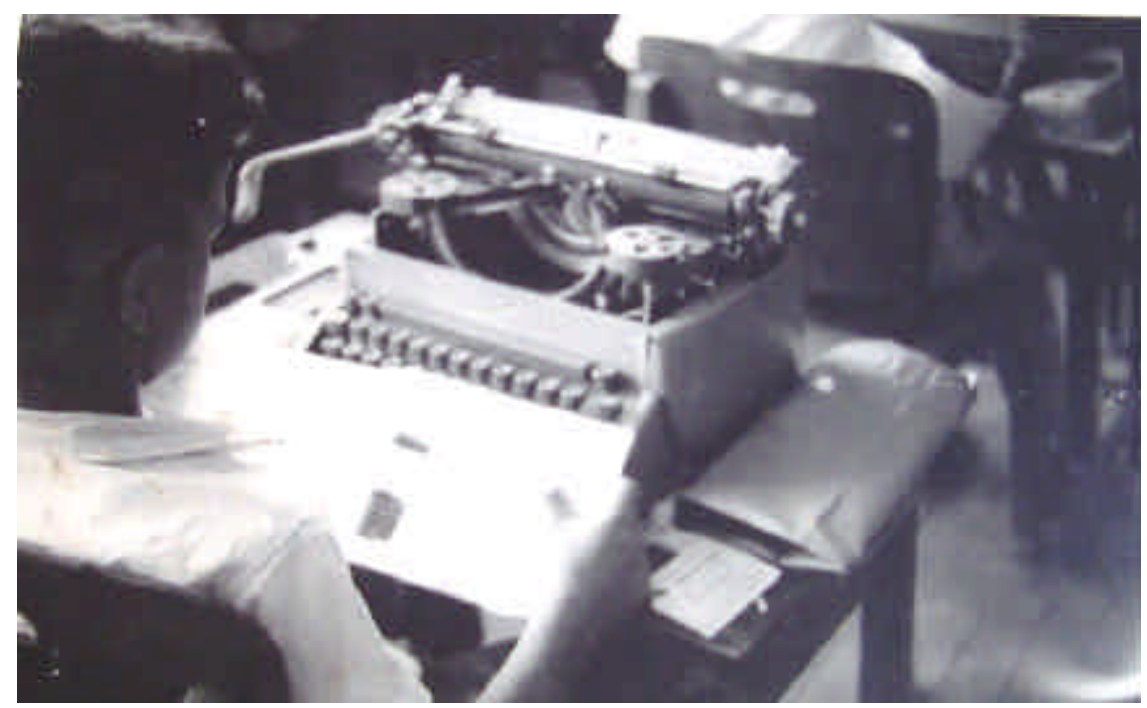

Figura 10. Aula de Datilografia no GVCP.

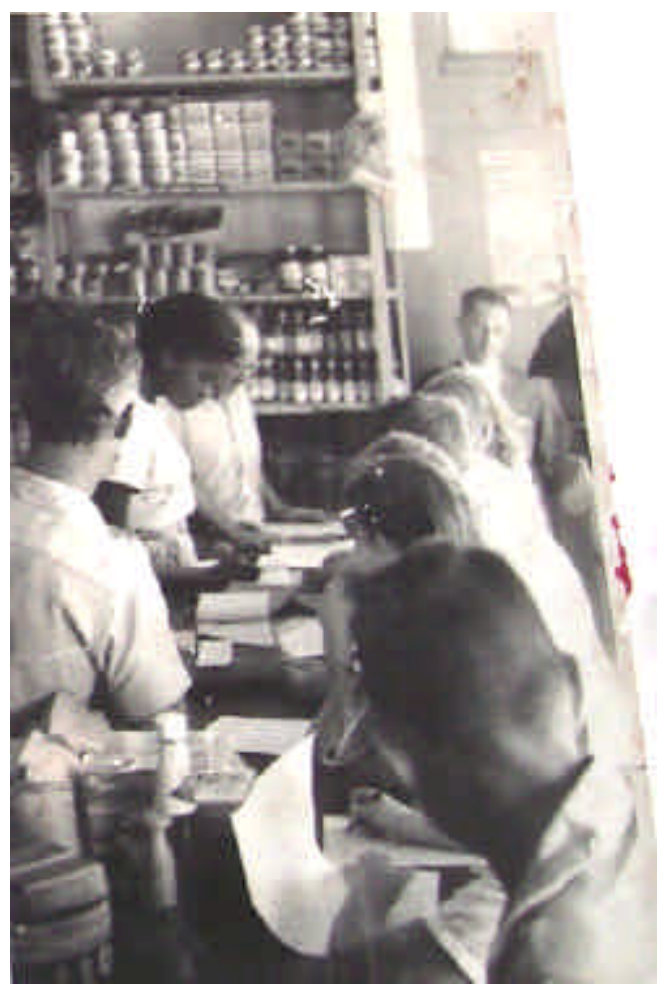

Figura 11. Cooperativa no GVCP. 
Os relatos anteriores, juntamente com as fotos ilustrando as práticas, parecem confirmar que no Vocacional procurava-se oferecer aos jovens estudantes vivências que pudessem prepará- los para a vida, como já foi destacado no item 2.2 deste trabalho.

Embora os ex-alunos tenham apontado praticamente todas as Instituições Didático-Pedagógicas presentes no PPA, eles pouco se aprofundaram na descrição da maioria delas. Uma das exceções foi o Acampamento, atividade que também possibilitava aos alunos uma vivência fora da escola. Conforme relata um ex-aluno, o local de realização destes acampamentos:

[...] geralmente eram fazendas de pai de aluno. Nós visitamos muitas fazendas. Tinha a fazenda "Boa Esperança", que [...] tinha produção de lã, então nós íamos na época da tosquia [...]. O acampamento era uma atividade de recreação, tinha todo aquele trabalho de olhar as estrelas e conhecer. Os meninos é que cuidava da segurança do acampamento. Então, tinha o plantão (J.M., 17 nov. 2006).

Enquanto isso, as meninas "[...] montavam as tendas. Ficamos no mato mesmo, montamos tendas e lá a gente dormia no chão, naquelas caminhas. E fazíamos a refeição ali mesmo. Ficamos dois ou três dias nessa fazenda” (M.E, 17 nov. 2006).

Esses dois últimos relatos reforçam mais uma vez que o trabalho em equipe era prática constante nas atividades dos Ginásios Vocacionais. As fotos das Figuras 12 e 13 registraram dois momentos de preparação do Acampamento.

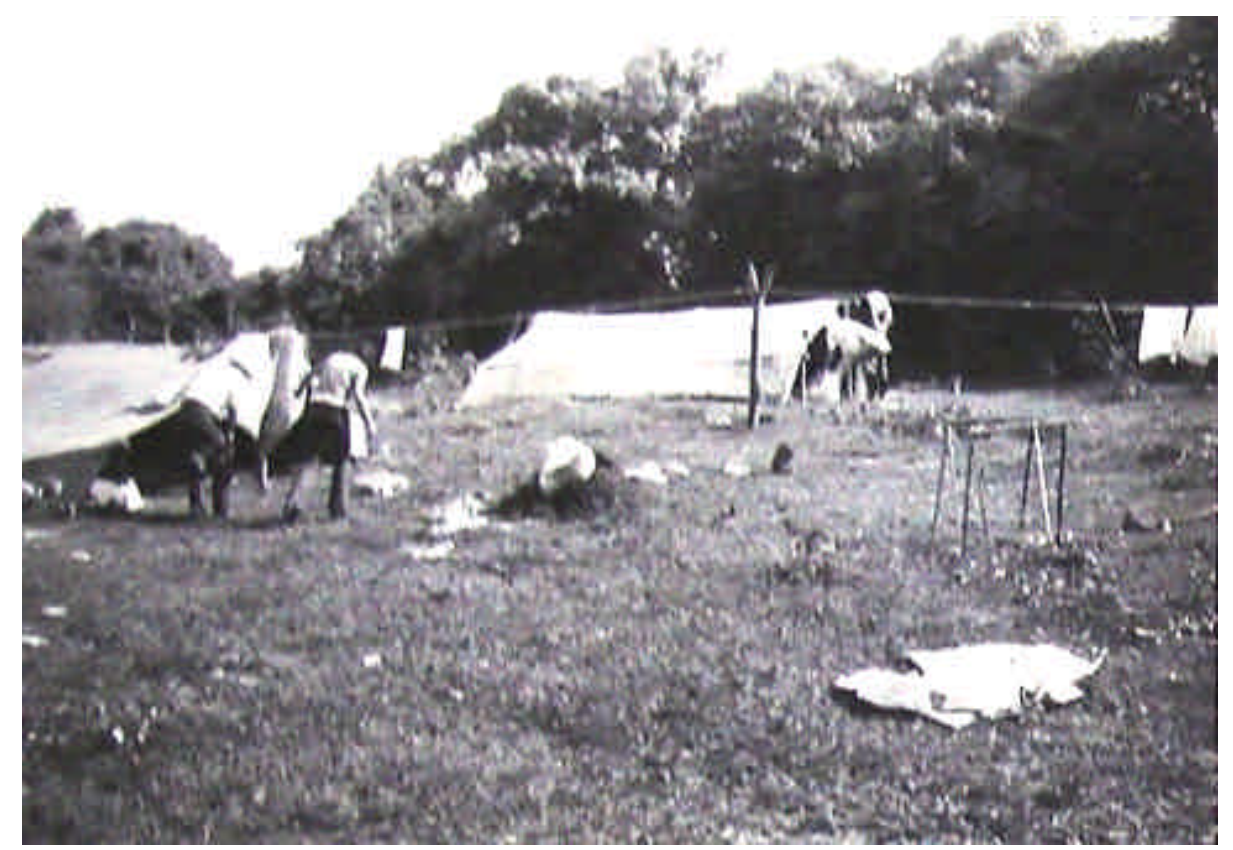

Figura 12. Acampamento do GVCP: montagens das tendas. 


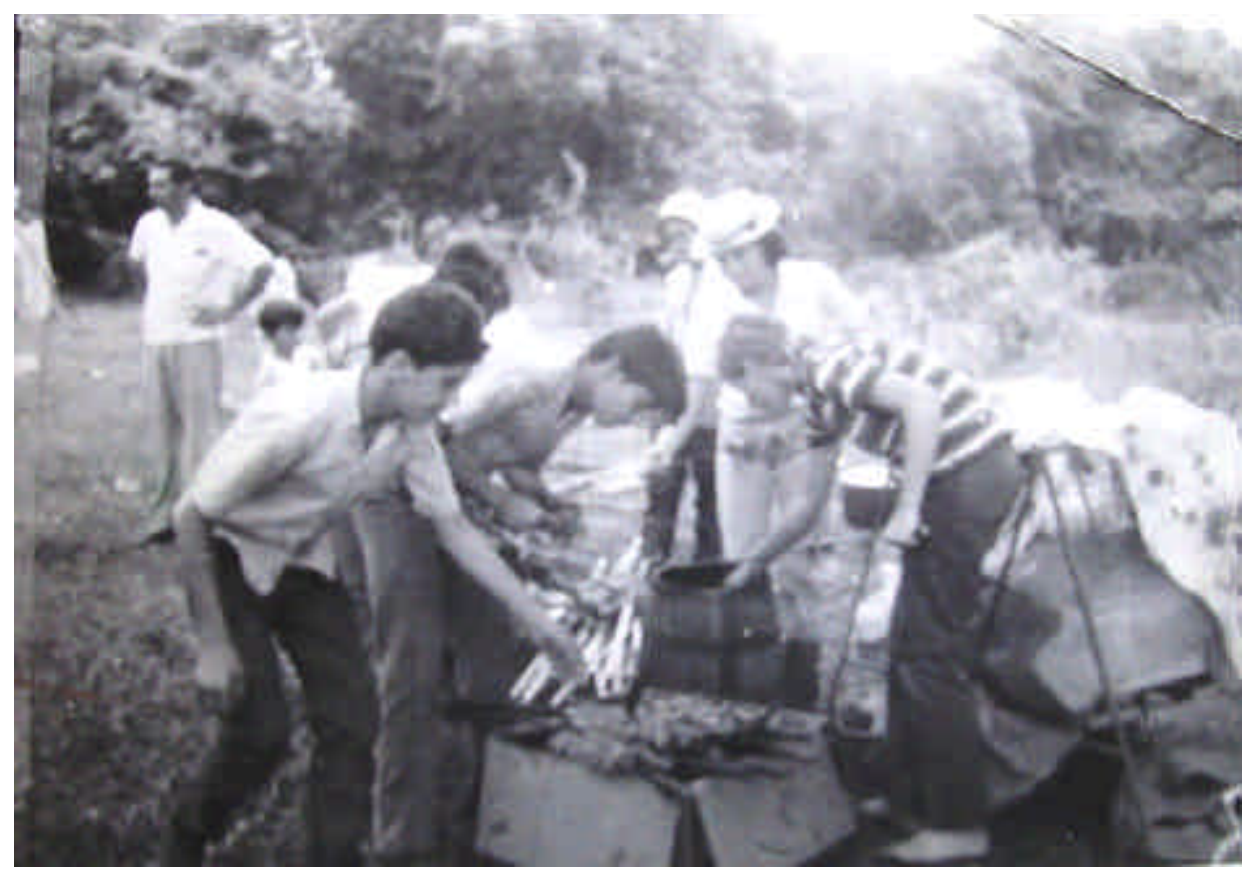

Figura 13. Acampamento do GVCP: chegada ao local.

Os temas Governo Estudantil e Economia Doméstica foram tratados por sete dos ex-alunos nas entrevistas.

No que se refere ao Governo Estudantil, os relatos dos ex-alunos e as fotografias desta atividade revelam muito mais de seu funcionamento, que o espaço dedicado pelo PPA a esta prática. Ela foi relatada como "[...] mais uma tentativa da Equipe Vocacional para trazer a educação da política, começar a formar o aluno” (J.M., 17 nov. 2006). Sobre suas eleições, um ex-aluno comenta:

[...] o Governo [Estudantil] ensinou a gente a votar. [...] Prefeito, deputado. Nós fizemos com urna, separamos as salas, colocamos urna lacrada, [...] voto secreto. Foi a maior briga! A gente fazia propaganda, boca de urna, tudo igualzinho, igualzinho... (A.A., 01 nov. 2005).

Um ex-aluno explica com maiores detalhes sobre sua experiência nesta atividade do GVCP:

Eu fui candidato a deputado e fui eleito. A eleição era anual e eu fui eleito por dois anos. [...] Quando deputado, nós trabalhamos a Constituição. Por dois anos nós fizemos a adaptação da Constituição à realidade da escola. Então, nós tivemos que estudar a Constituição e moldá-la para a escola. Tinha as reuniões da Assembléia, porque era a nível de estado e, por outro lado, também tinha as aspirações: a cantina, a melhoria da cooperativa, a melhoria do banco, tudo essas coisas que os eleitores pleiteavam dos deputados para que eles levassem a efeito (J.M., 17 nov. 2006) 
Nas fotos das Figuras 14 a 16, é possível verificar três momentos distintos do processo de eleição do Governo Estudantil no GVCP.

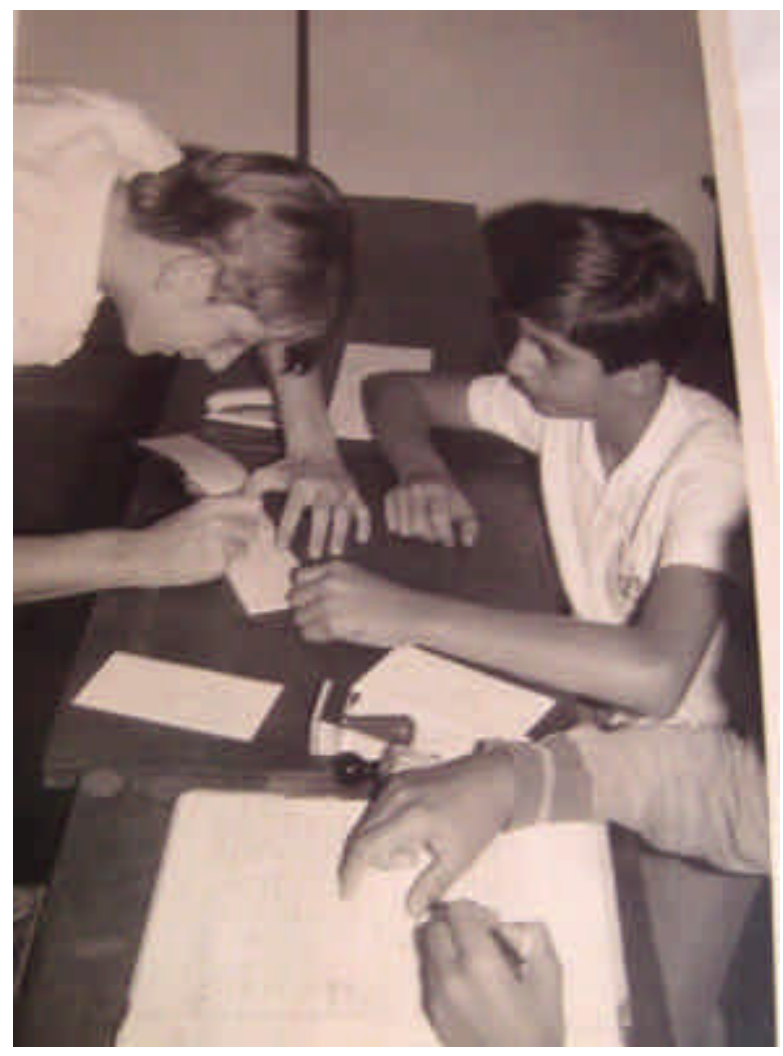

Figura 14. Governo Estudantil: momento de eleição.

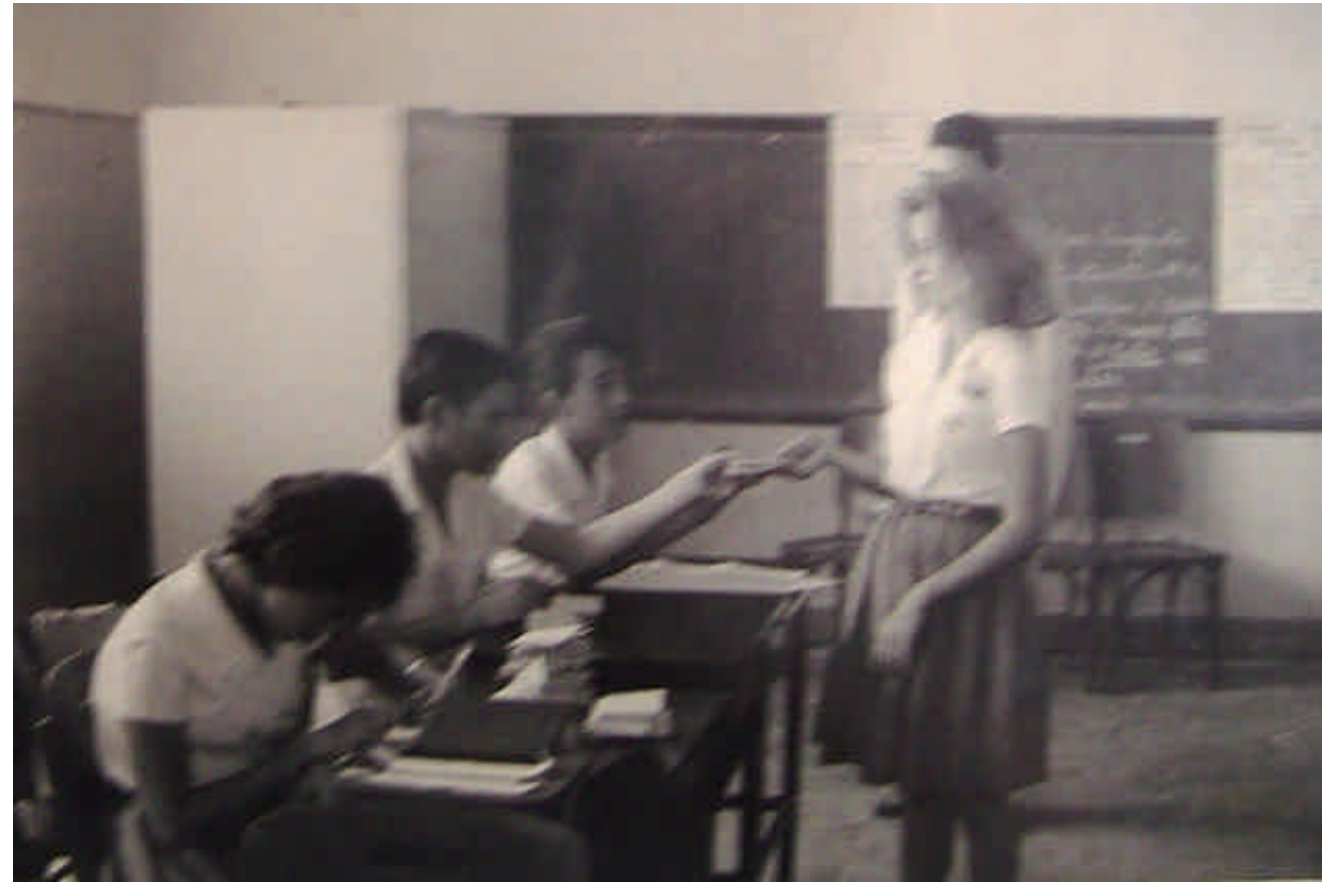

Figura 15. Governo Estudantil: entrega de título de eleitor. 


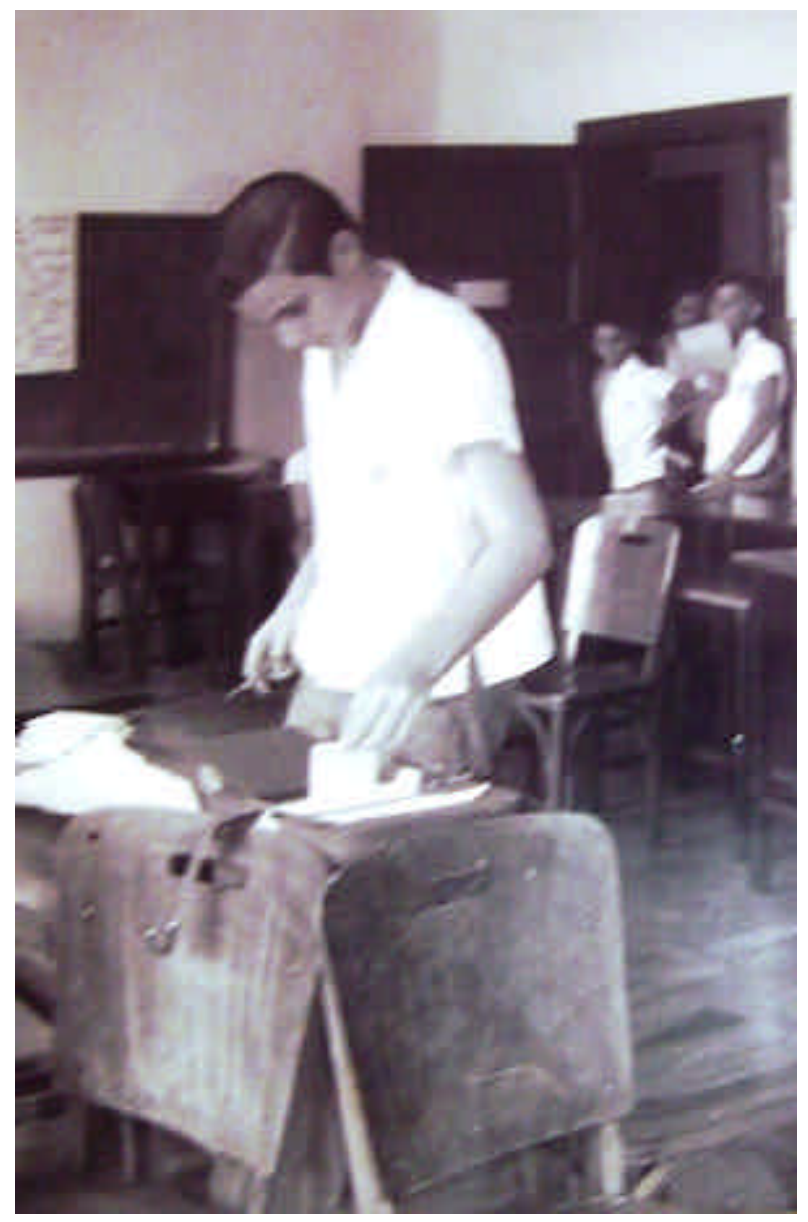

Figura 16. Governo Estudantil: votação.

Quanto às atividades desenvolvidas em Economia Doméstica, os alunos destacaram que esta era "[...] mista, ia pra cozinha homem e mulher, fazia comida e convidava as mães para experimentar. Aprender a arrumar a mesa, como se coloca um garfo, uma faca, como se portar na mesa” (J.M., 17 nov. 2006). Um outro aluno confirma: “[...] h́ você aprendia a cozinhar, como organizar uma casa - porque lá tinha a prática de culinária. Era uma casa, você dificilmente via sujo o chão no vocacional” (P.I., 17 nov. 2006).

Lembrando a informação apresentada pelo PPA e relatada no item 3.3, a Economia Doméstica possuía uma sala adaptada especificamente para seu funcionamento. Isto permitia além do desenvolvimento desta prática, o envolvimento dos alunos com a comunidade. Conforme relata um ex-aluno:

[...] a gente sempre convidava as pessoas ou as crianças [para a atividade de Economia Doméstica]. A gente levava, cuidava, dava banho, ensinava a higiene. Isso tudo a gente aprendia lá, a gente fazia com o pessoal da comunidade [...] (A.A., 01 nov. 2005). 
As fotos apresentadas nas Figuras 17 a 19, ilustram algumas atividades na prática de Economia Doméstica no GVCP.

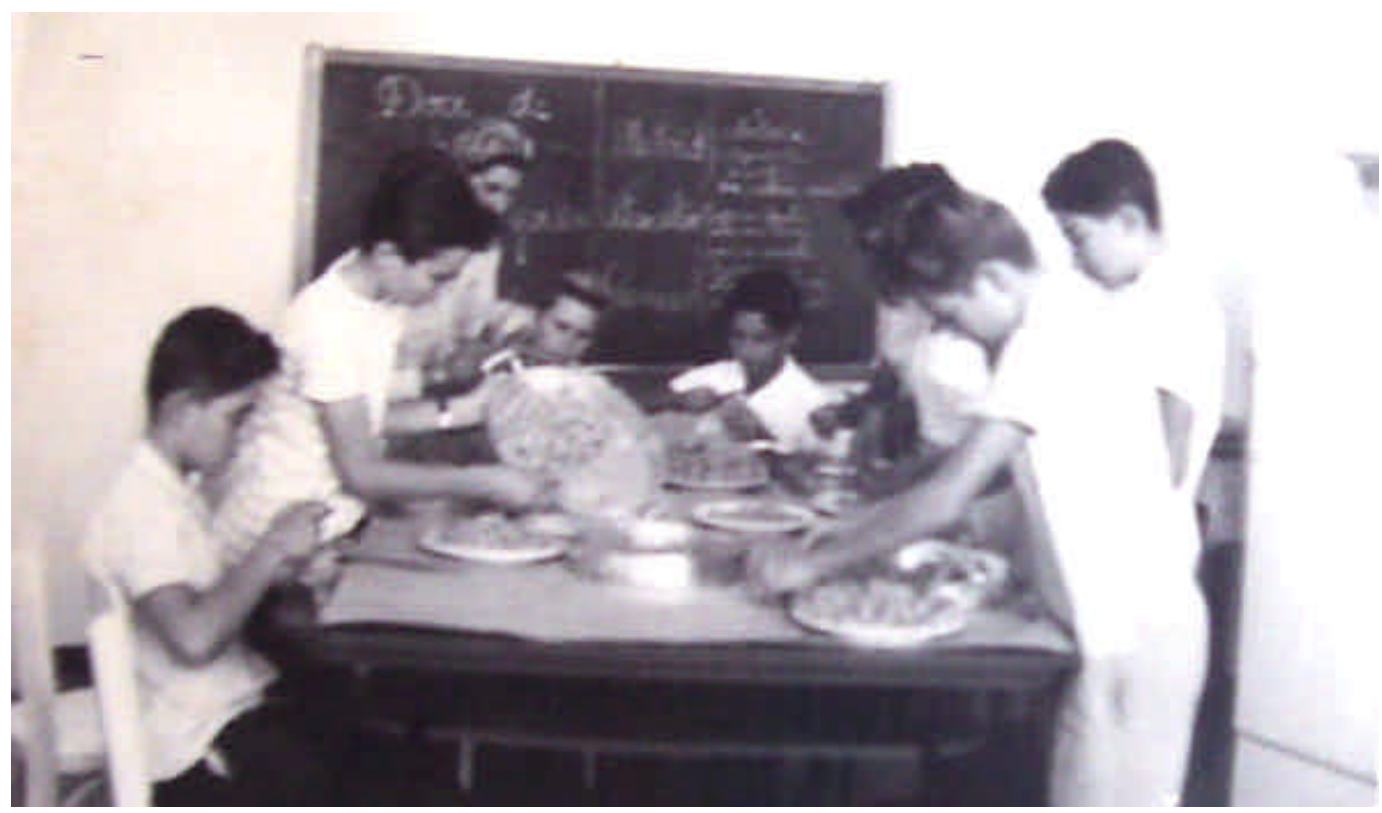

Figura 17. Economia Doméstica no GVCP: aulas de culinária.

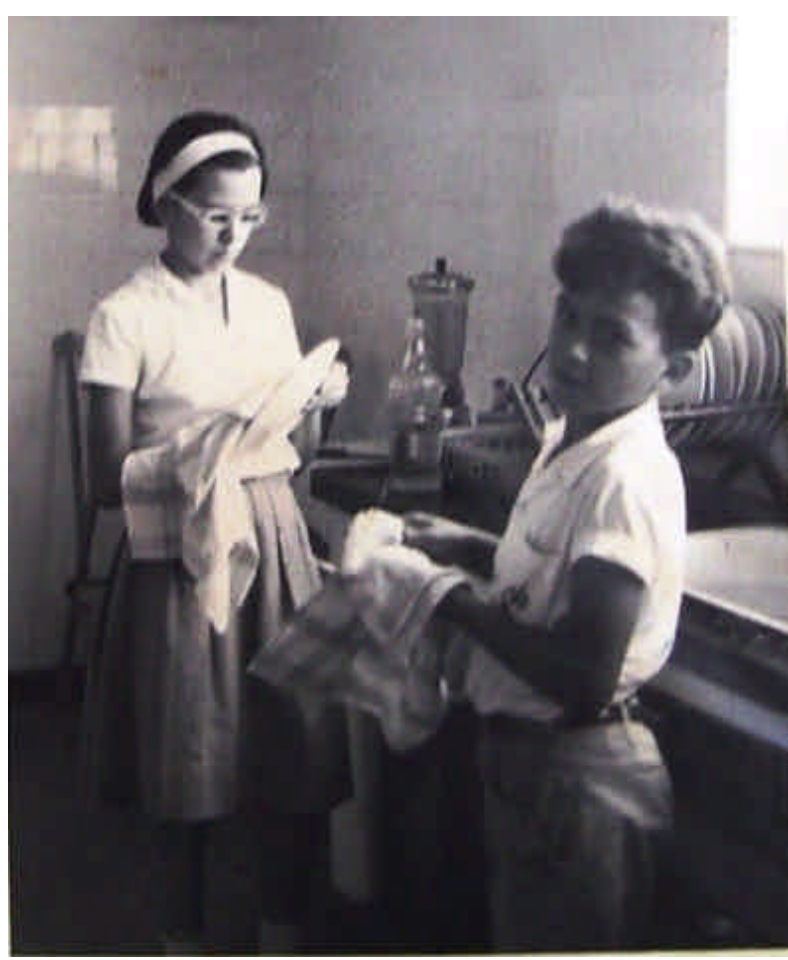

Figura 18. Economia Doméstica no GVCP: lavando louça. 


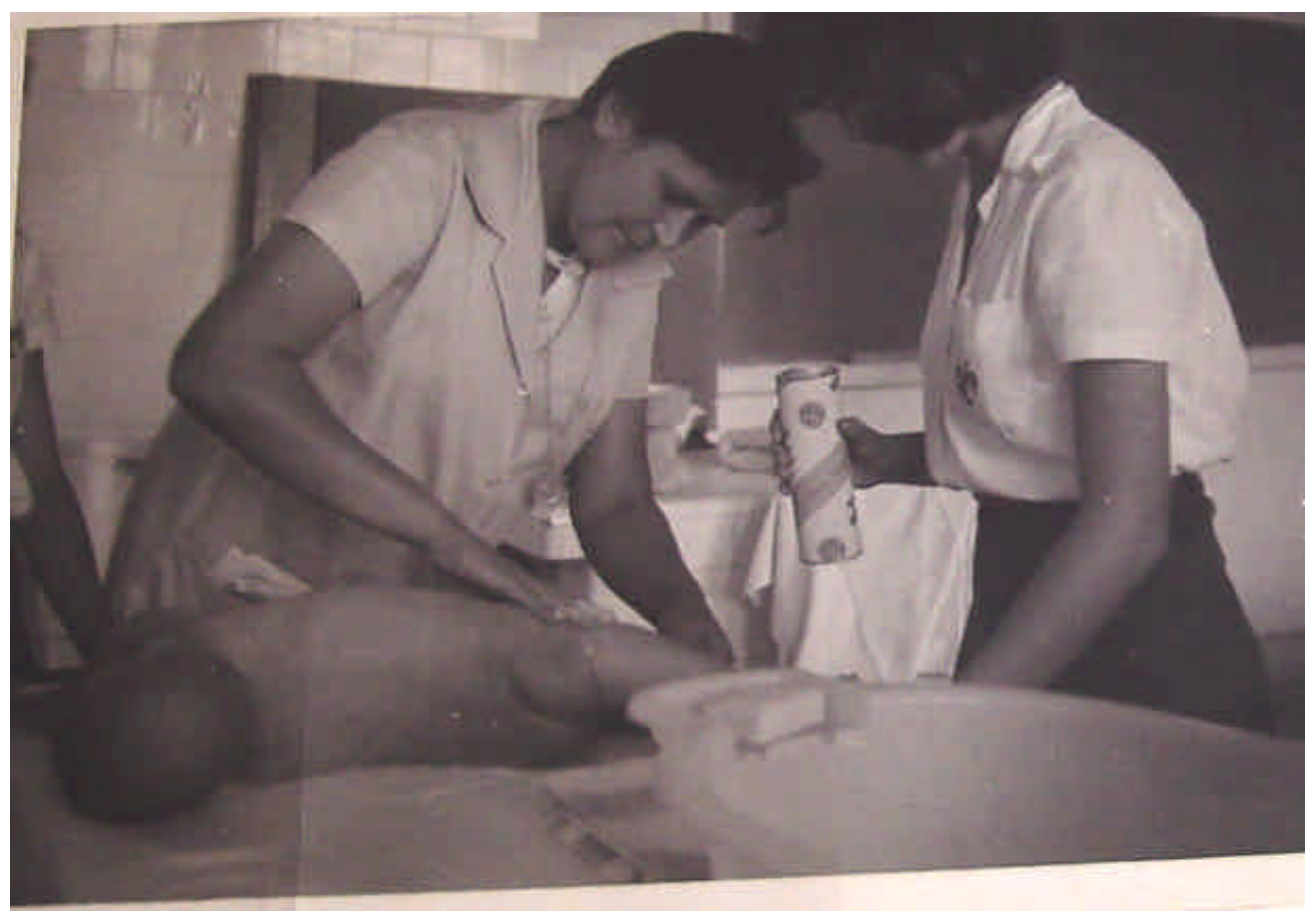

Figura 19. Economia Doméstica no GVCP: cuidar de crianças.

As Práticas Agrícolas foram mencionadas por quatro ex-alunos. Um deles assim as descreve: “[...] nós tínhamos a prática de cuidar da horta da escola, de produzir verdura e frutas, [...] tinha visitas a campo, [para] visitar as propriedades agrícolas" (J. M., 17 nov. 2006). Outro ex-aluno completa: “[...] em Práticas Agrícolas eu aprendi! Eu não esqueço de jeito nenhum como fazer a transposição da muda de alface de um lugar. Depois tinha que colocar num canteiro direitinho" (R.B., 17 nov. 2006). Estas Práticas foram abordadas apenas por meio dos relatos dos ex-alunos e das informações contidas no item 3.2 deste capítulo, uma vez que não foram encontradas fotografias que registraram as mesmas.

Um tema muito enfatizado nos depoimentos dos ex-alunos do GVCP foi a relação estabelecida entre professores e alunos e entre os próprios alunos. Essa relação parece ter sido o que mais marcou a vida escolar destes alunos, porque:

[...] no vocacional existia uma amizade entre professor, alunos, pais de alunos da Associação de Pais e Mestres do Vocacional Uma interação que faria inveja hoje às sociedades mais organizadas. Então, essa interação, essa forma amigável, o sistema de ensino, tudo marcou por demais o Sistema Vocacional (R.O., 17 nov. 2006).

Em outro relato, um ex-aluno afirma: 
[...] o que mais deixou marcas [na Experiência do GVCP] foi o relacionamento entre os ex-colegas que perdura até hoje e que faz com que a gente se identifique uns com os outros. E nos faz perceber que essa distância, nesse período que ficamos sem contato pós-vocacional, foi mitigada, como se não houvesse. Como se fosse ontem (R.E., 01 nov. 2006).

Quanto à relação entre os alunos e professores, verificou-se que todos os exalunos entrevistados fizeram questão de registrar que:

[...] os professores eram amigos da gente. Eles não eram professores, eles eram amigos. $\mathrm{O}$ que você precisava, eles tavam ali, porque eles ficavam na escola o dia todo. Então, eles se dedicavam ao aluno dia todinho. Não como o professor que fica hoje, de uma escola pra outra. Não dá nem tempo de conversar (A.A., 01 nov. 2005).

E para finalizar essa questão, a seguinte alusão de um ex-aluno sintetiza esta relação: “[...] o Vocacional era uma família! Quando se tinha reunião, fechava aquilo tudo!" (R.O., 01 nov. 2005).

O último tema a ser tratado neste item refe re-se à Orientação Vocacional. Por ser uma escola voltada para a formação integral do cidadão, o GVCP prepara va seus alunos não só para o trabalho, mas também para a vida em sociedade. Entretanto, o direcionamento vocacional era um fator muito significativo na proposta. Este fato é observado pelo discurso dos ex-alunos:

[...] ele [o Vocacional] definiu minha vida. Ele que me indicou Educação Física e Serviço Social. Eu queria ajudar alguém e depois que eu descobri que era Serviço Social [minha vocação] [...]. O Vocacional serviu para minha vida inteirinha. Ele me deu uma abertura. O jeito que eu entrei lá, se não tivesse o Vocacional, eu não tinha continuado os estudos. Quem me preparou para conseguir uma bolsa de estudos na faculdade? O Vocacional! (P.I., 17 nov. 2006)

Essa orientação somente era possível:

[...] pelo fato da gente permanecer na escola durante o período integral, os professores observavam muita a tendência de cada aluno, a aptidão de cada aluno por matérias. Quando chegou ao nível que seria da oitava série - que no nosso tempo era a quarta série ginasial - a gente foi orientado e os pais foram chamados e cada um direcionado (R.O., 17 nov. 2006).

Um ex-aluno faz o seguinte relato a respeita da Orientação Vocacional: 
[...] eu lembro direitinho que um dia minha mãe foi chamada no fim da quarta-série e foi dado o relatório pra ela dizendo: "olha, nós fizemos avaliação de todos esses anos, então ela pode seguir a profissão de enfermagem". [...] É uma coisa que ficou, que eu realmente gostaria disso. Eu nunca pensei de jeito nenhum em fazer medicina. Tem gente que fala assim: "mas você fez enfermagem, mais um pouquinho você fazia medicina". Não, é completamente diferente uma coisa da outra. Eu nunca, nunca tive pretensão de fazer medicina. Tanto é que a enfermagem pode usar o título de doutor e tudo, mas eu nunca quis, detesto! (R.B., 17 nov. 2006).

Tais relatos vão de encontro à proposta de Orientação Vocacional explicitada no PPA, que a considera como o resultado de todo um processo educativo desenvolvido nas quatro séries ginasiais. Ele leva o aluno ao reconhecimento de suas aptidões por meio do treino de opções e o norteia em suas escolhas profissionais. 



\section{$C_{\text {onsiderações }} \bar{F}_{\text {inais }}$}

Essa pesquisa é o resultado do esforço em compreender e analisar as práticas desenvolvidas no GVCP. Para tanto, fiz uso dos depoimentos de seus ex-alunos, de fotografias de época, dos Planos Pedagógicos e Administrativos dos Ginásios Vocacionais e de estudos sobre o tema "Ginásios Vocacionais". Esse exercício mostrou a necessidade do pesquisador utilizar um olhar crítico em suas análises das fontes disponíveis, de forma a se evitar uma leitura "apaixonada" do tema abordado.

Trabalhar com os depoimentos dos ex-alunos foi um desafio, pois a todo instante era preciso atentar para a possibilidade de estes depoimentos esconderem outros. Trabalhar com depoimentos transcritos é mais do que criar arquivos, produzir um resumo de histórias individuais que são também sociais. Apesar de passados quase quarenta anos das vivências no GVCP, seus ex-alunos raramente teceram críticas sobre a experiência Vocacional.

Outro aspecto importante a ser revelado é o ambiente onde as entrevistas deste trabalho foram realizadas: igreja, local de trabalho, residência e sala de reunião do Hotel onde fiquei instalada. Estou chamando a atenção para isso porque é preciso dizer o lugar de onde os depoimentos são colhidos para se entender as representações utilizadas no discurso dos entrevistados. A entrevista, mais do que uma técnica ou um método de pesquisa, foi um encontro intencional e, de certa forma, controlado entre sujeitos que aos poucos vão dando sentido às suas narrativas no momento em que as constrói/reconstrói. O tempo todo buscaram fazer uma representação da experiência vivida e de si mesmos. Nesses depoimentos foi possível perceber também quais atividades (práticas) que mais marcaram essa etapa de suas vidas e as diferentes formas com que essas atividades foram apropriadas.

O uso do Livro de Matricula para se construir o público alvo do GVCP também se mostrou um grande desafio nesta pesquisa, por conta principalmente de minha inexperiência no trato com este tipo de documento e do desconhecimento dos critérios utilizados para o preenchimento dos campos deste livro. Algumas ambigüidades foram encontradas nas informações contidas neste documento. Por exemplo: datas de nascimento 
distintas para um mesmo aluno de um ano para outro; profissão do pai preenchida como falecido em um ano e, no ano seguinte, como fazendeiro; uso de traço ( - ) e aspas ( ") mo campo da profissão, levando a dúvidas de interpretação; dentre outras.

Do conjunto de questões que nortearam esta pesquisa foi possível, senão obter respostas, ao menos fazer alguns apontamentos para a maior parte delas. A primeira questão levantada foi quanto às motivações políticas e pedagógicas que definiram a cidade de Batatais como uma das unidades Vocacionais. O que se conseguiu perceber é que Batatais reunia características distintas das outras cidades onde a experiência seria implantada, por localizar-se em uma região predominantemente agrícola. Mais que isto, ela possuía um prédio pronto para uso e com condições para adequação às necessidades da proposta.

A questão levantada em seguida referiu-se aos critérios de ingresso de alunos no GVCP. Esses critérios já estavam descritos no PPA e foram confirmados por meio dos depoimentos dos ex-alunos entrevistados. Basicamente, eles se constituíam de um exame de admissão e uma entrevista.

Outra questão investigada nesta pesquisa foi sobre o público alvo do GVCP. Este, pelo que pôde ser constatado no Livro de Matricula, se constituiu em maior parte de meninos. Pelos dados analisados, percebe-se que o ingresso de meninas aumentou com o passar dos anos da experiência (mais que dobrou), ao mesmo tempo em que a idade dos alunos ingressantes diminuiu (da idade média de 12 anos para 10 anos).

Foi um comentário comum entre os entrevistados que, neste Vocacional, havia a convivência de todos os extratos sociais sem que alunos pudessem perceber. Os dados referentes à profissão dos pais contidas no Livro de Matricula possibilitam inferir tal convivência. Porém, quando analisado em termos percentuais, o número de pais com profissões que se identificam com as classes sociais mais baixas foi significativamente inferior aos das classes média e média-alta. Este fato ajudou a responder a quarta questão proposta nesta pesquisa. Ela tratou do perfil dos pais dos alunos, buscando caracterizar por meio de suas profissões, a representação das diversas camadas da sociedade no GVCP.

Uma questão seguinte referiu-se também aos pais dos alunos, porém abordando a participação destes nas atividades desenvolvidas no Vocacional. Mediante as informações obtidas com os ex-alunos entrevistados, foi possível notar que o envolvimento dos pais no GVCP deu-se através das reuniões da Sociedade de Pais e Amigos do Vocacional e na organização de eventos. Tal envolvimento fora previsto no PPA com o objetivo de leválos a uma participação consciente no processo educativo de seus filhos. 
A última questão levantada abordou as práticas que caracterizam a experiência do GVCP. De modo geral, as práticas desenvolvidas nesta unidade não diferiram substancialmente das desenvolvidas nos demais Vocacionais. As mais lembradas nos depoimentos dos ex-alunos foram: o Trabalho em Equipe, o Estudo do Meio, o Governo Estudantil, as Práticas Agrícolas, Comerciais e Industriais, e as aulas de Economia Doméstica.

Finalizo estas considerações chamando atenção para o que de fato configurou a experiência do GVCP como singular: sua inovação, pois se revela como uma proposta única, impressa organicamente no PPA, porém construída em um projeto pedagógico junto à comunidade, com a interdisciplinaridade muito presente. Isso tudo mostra que os princípios que nortearam os Ginásios Vocacionais constituem-se de sofisticações para qualquer proposta educacional e que, por isso mesmo, não é uma experiência repetível. Sei que não consegui avançar em muitas questões, mas essas ficam em aberto para outros trabalhos de pesquisa. 



\section{$R_{\text {eferências }} \mathrm{B}_{\text {ibliográficas }}$}

AZANHA, José M. P. Democratização do ensino: vicissitudes da idéia no ensino paulista. Cadernos de História e Filosofia da Educação, São Paulo, Faculdade de Educação, Universidade de São Paulo, v.1, n.1, p.13-20, 1993.

BALZAN, Newton C. Estudos Sociais: opiniões e atitudes de ex-alunos. 1973. 187 f. Tese (Doutorado em Educação) - Faculdade de Filosofia, Ciências e Letras de Presidente Prudente, Universidade Estadual Paulista "Júlio de Mesquita Filho", Presidente Prudente, 1973.

BARBIERI, José H. Batatais e sua evolução histórica, Batatais/SP: Secretaria Municipal de Cultura; Museu Histórico Washington Luis, 1997 (digitado).

Outrora Batatais, Batatais/SP: Secretaria Municipal de Cultura; Museu Histórico Washington Luis, 1998 (manuscrito).

BEISEIGEL, Celso R. Estado e Educação Popular: um estudo sobre a educação de adultos. São Paulo: Pioneira, 1974.

O ensino médio sob a perspectiva da educação básica. In: ZIBAS, Dagmar, AGUIAR, Márcia, BUENO, Marias. O ensino médio e a reforma da educação básica. Brasília: Plano Editora, 2002.

BRAGHINI, Kátia M. Z. O Ensino Secundário Brasileiro nos anos 1950 e a questão da Qualidade de Ensino. 2005. 164 f. Dissertação (Mestrado em Educação) - Pontifícia Universidade Católica, São Paulo, 2005.

CAMPOS, Francisco. Educação e Cultura. 2 ed. Rio de Janeiro: Livraria José Olympio, 1941.

CARDOSO, Clotilde M. C. S. IESA de Ouro (1948- 1998). (org). Batatais: s.p.c, 1999.

CERTEAU, Michel de. A invenção do cotidiano: 1. Artes de fazer. Petrópolis, RJ: Vozes, 1994. Tradução de Epharaim Ferreira Alves, nova edição estabelecida e apresentada por Luce Girard. 
CHIOZZINI, Daniel F. Os Ginásios Vocacionais: A (Dês)construção da História de uma experiência educacional transformadora (1961-69). 2003. 125 f. Dissertação (Mestrado em Educação) - Faculdade de Educação, Universidade Estadual de Campinas, Campinas, 2003.

CUNHA, Marcus Vinicius da. John Dewey: a utopia democrática. DP\&A: Rio de Janeiro, 2001.

ESCOLANO, Agustín. Arquitetura como programa espaço-escola e currículo. In: Currículo, espaço e subjetividade: a arquitetura como programa. Rio de Janeiro: DP\&A, 1998.

FARIA FILHO, Luciano M.; VIDAL, Diana G. et ale. A cultura escolar como categoria de análise e como campo de investigação na história da educação brasileira. Educação \& Pesquisa, vol. 30, m.1, jan/abr. 2004, p.139-160.

Escolarização, culturas e práticas no Brasil: elementos teórico-metodológicos de um programa de pesquisa. In: Lopes, Alice. C; Macedo, Elizabeth. Disciplinas e integração curricular: história e políticas. Rio de Janeiro; DP\&A, 2002.

FAUSTO, Boris. A Revolução de 1930. São Paulo: Companhia das Letras, 1997.

FERNANDES, José M. M. (Org.). Batatais: a cidade dos mais belos jardins. São Paulo: Noovha América, 2004. 80 p.

FONTES, Alice A. B. Inovações Educacionais: Autores e Atores das classes experimentais. 1999. Tese (Doutorado) - Faculdade de Educação, Universidade de São Paulo, 1999.

FONTES, Sônia. M. História Oral: Possibilidades e Procedimentos. Associação Editorial Humanitas, São Paulo, 2006.

GRAZZIONTIN, Francine. Imprensa: considerações para seu uso como fonte histórica. Semina: Cadernos dos Pós-Graduandos do Programa de Pós-Graduação em História, Universidade de Passo Fundo, v.4(1), p.1-7, 2006.

HALBWACHS, Maurice. A memória coletiva. São Paulo: Vértice, 1990.

HILSDORF, Maria L S. História da Educação Brasileira: Leituras. São Paulo: Pioneira Thonsom Learning, 2003. 
JACOBUCCI, Ary M. Revolucionou e Acabou? Breve etnografia do Ginásio Estadual Vocacional de Americana: GEVA. São Carlos, SP: Editora Compacta, 2002.

KOSSOY, Boris. Realidades e ficções na trama fotográfica. São Paulo: Ateliê Editorial, 2000, p. 25-60; p. 127-142.

LE GOFF, Jaques. Documento/Monumento. In Memória e História, Lisboa: Imprensa Nacional, 1984.

LOPES, E. M. T. História da Educação. (Org). Ana Maria de Oliveira Galvão. Rio de Janeiro: DP\&A, 2001.

MARQUES, Sandra M. L. Contribuição ao estudo dos Ginásios Vocacionais do Estado de São Paulo: o Ginásio Vocacional "Chanceler Raul Fernandes" de Rio Claro. 1985. Dissertação (Mestrado em Filosofia) - Pontifícia Universidade Católica, São Paulo, 1985.

MASCELANI, Maria N. Uma pedagogia para o trabalhador: o Ensino Vocacional como base para uma proposta pedagógica de capacitação profissional de trabalhadores desempregados (Programa Integrar CNM/CUT). 1999. 322 f. Tese (Doutorado em História e Filosofia da Educação) - Faculdade de Educação, Universidade de São Paulo, São Paulo, 1999.

NUNES, Clarice \& CARVALHO, M, M, C. História da Educação e Fontes. In: Cadernos da ANPED. Porto Alegre, n.5, Set, 1993, p.7-64.

O "velho" e o "bom" ensino secundário: momentos decisivos. In: Revista Brasileira de Educação, ANPED. n.14, Mai/Juh/Jul/Ago, 2000. p.35-60 (Site visitado em 29/05/07).

PINHO, Margarida G. A. Ensino de Artes Plásticas nos Ginásios Estaduais Vocacionais: 1961-1969. 1983. Dissertação (Mestrado) - Faculdade de Comunicação e Artes, Universidade de São Paulo, São Paulo, 1983.

PISANI, Salvatore. Lo Stato di San Paolo nel cinquantenario dell'immigrazione. San Paolo: Salerno, 1937.

POLAKKI, Michelle. Memória e identidade social. In: Estudos Históricos. v.5. Rio de Janeiro/RJ, Brasil, 1992.

ROMANCINI, R.. História e Jornalismo: reflexões sobre campos de pesquisa. In: Anais do Congresso Brasileiro de Ciências da Comunicação, n.28, Rio de Janeiro, 2005. 
ROVAI, Esméria. As cinzas e a brasa: Ginásios Vocacionais: Um estudo sobre o processo de ensino-aprendizagem na experiência pedagógica do Ginásio Estadual Vocacional "Oswaldo Aranha" (1962/1969). 1996. Tese (Doutorado em Psicologia da Educação) Pontifícia Universidade Católica, São Paulo, 1996.

(org). Ensino Vocacional: Uma Pedagogia Atual. São Paulo: Cortez, 2005.

SAMUEL, Raphael. Teatros de memória. In: Projeto História. São Paulo, n.14. p.41-82, 1997.

SPÓSITO, Marília P. O Povo vai à Escola - A luta popular pela expansão do ensino público em São Paulo. In: Coleção Educação Popular, 3a., São Paulo: Editora Loyola, 1992.

SOUZA, Rosa F. Templos de Civilização: Um estudo sobre a implantação dos Grupos Escolares no Estado de São Paulo (1890-1910). 1997. 307 f. Tese (Mestrado em Educação) - Faculdade de Educação, Universidade de São Paulo, São Paulo, 1997.

SQUEFF, E. (org). A origem dos nomes dos municípios paulistas. São Paulo: Fundação Prefeito Faria Lima - CEPAM. Imprensa Oficial do Estado de São Paulo, São Paulo, 2003, 312p.

TAMBERLINI, Angela R. M. B. Comunitarismo e Educação: Implicações e Limites. 2003. 263 f. Tese (Doutorado em Educação) - Faculdade de Educação, Universidade de São Paulo, São Paulo, 2003.

. Os Ginásios Vocacionais: a dimensão política de um projeto pedagógico transformador. São Paulo: Annablume: Fapesp, 2001.

Os Ginásios Vocacionais, a História e a possibilidade de futuro. In: Rovai, E.(org.). Ensino Vocacional: Uma Pedagogia Atual. São Paulo: Cortez, 2005.

Os Ginásios Vocacionais: a dimensão política de um projeto pedagógico transformador. 1998. 181 f. Dissertação (Mestrado em Educação) Faculdade de Educação, Universidade de São Paulo, São Paulo, 1998.

THOMPSON, Paul. A voz do passado: a história oral. Rio de Janeiro: Editora Paz e Terra, 1992.

THOMSON, Alistar. Recompondo a Memória: Questões sobre a relação entre a História Oral e as Memórias. In: Projeto História, no.15, São Paulo: PUC, 1997. 
VIDAL, Diana G. (org) Na batalha da educação: correspondência entre Anísio Teixeira e Fernando de Azevedo (1929-1971). Bragança Paulista: EDUSF, 2000.

A Fotografia como Fonte para a Historiografia Educacional sobre o Século XIX: uma primeira aproximação. In: FARIA FILHO, Luciano M. (org). Educação, Modernidade e Civilização. Belo Horizonte: Autêntica, 1998.

De Heródoto ao gravador: histórias da História Oral. In: Resgate: Revista Interdisciplinar de cultura do Centro de Memória. UNICAMP. Campinas: Papirus, no.1 . 1990, p.77-82. 



\section{$C_{\text {orpus }} D_{\text {ocumental }}$}

A FOLHA DE BATATAIS. Batatais (período de 1960-1970).

Fotografias do GVCP.

GINÁSIO ESTADUAL VOCACIONAL "CÂNDIDO PORTINARI". Livro de Matricula: Período de 1967-1969. São Paulo, 1968.

Acampamento.

(mimeo.). Batatais, 1965.

O JORNAL. Batatais (período de 1959-1970).

SERVIÇO DO ENSINO VOCACIONAL. Planos Pedagógicos e Administrativos dos Ginásios Vocacionais do Estado de São Paulo. (mimeo.). São Paulo, 1968a. 413 p.

Regimento Interno dos Ginásios Vocacionais.

(mimeo.). São Paulo, 1968b.

Relatório do RENOV: Extratos de uma Experiência Educacional. (mimeo.). São Paulo, 1968c. 